\title{
Alcohol consumption during pregnancy
}

Prevalence, predictors and prevention

\author{
Janna Skagerström
}

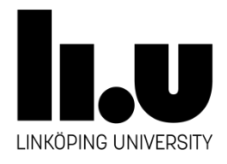

Division of Community Medicine Department of Medical and Health Sciences Linköping University, Sweden

Linköping 2015 

CJanna Skagerström 2015

Cover picture/illustration: Per Lagman, LiU-Tryck

Published articles have been reprinted with the permission of the copyright holders.

Printed in Sweden by LiU-Tryck, Linköping, Sweden, 2015

ISBN 978-91-7519-024-2

ISSN 0345-0082 
Making the decision to have a child - it's momentous. It is to decide forever to have your heart go walking around outside your body."

Elizabeth Stone 


\section{CONTENTS}

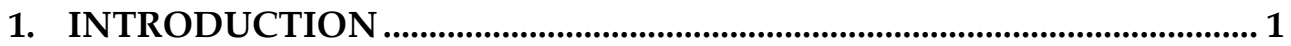

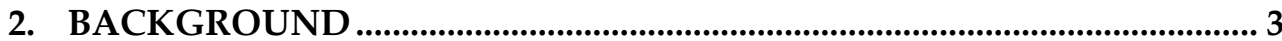

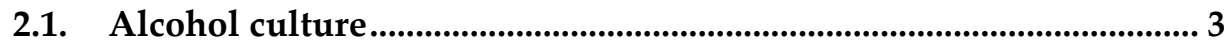

2.2. Alcohol consumption in Sweden ........................................................... 4

2.3. An international perspective on alcohol consumption before and during pregnancy ......................................................................................... 5

2.4. Effects of alcohol consumption during pregnancy ............................... 6

2.4.1 Binge drinking .........................................................................

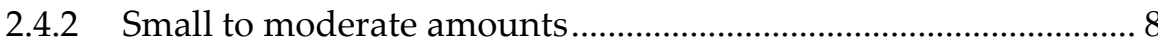

2.5. Fetal Alcohol Syndrome (FAS) and Fetal Alcohol Spectrum Disorder (FASD) ...................................................................................... 9

2.6. Alcohol-preventive work in Swedish antenatal care ........................ 11

2.7. Rationale for the thesis.......................................................................... 12

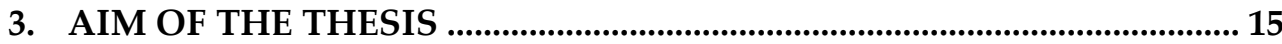

4. CONCEPTS AND THEORIES ................................................................ 17

4.1. Prevention and promotion ................................................................... 17

4.2. Social-cognitive theories of behavior change ………………………..... 19

4.3. Habit theory of behavior change........................................................... 20

4.4. Diffusion of innovations - a theory on the organizational and

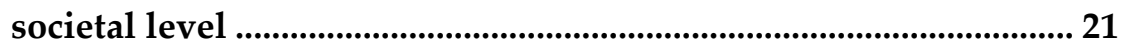

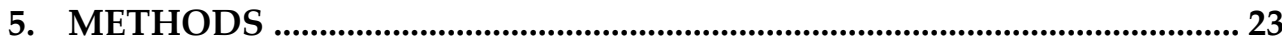

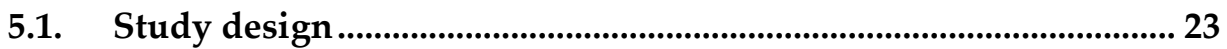

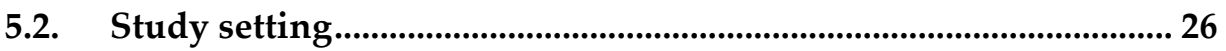

5.3. Population and sample....................................................................... 26

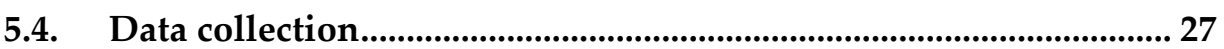

5.5. Data extraction scheme, questionnaires and interview guide....... 29

5.6. Data analysis ............................................................................................ 33 
5.7. Ethical concerns ................................................................................... 35

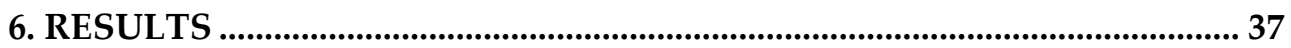

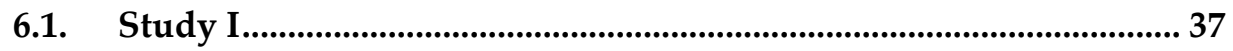

6.2. Study II .................................................................................................... 39

6.3. Study III......................................................................................................... 41

6.4. Study IV..................................................................................................... 42

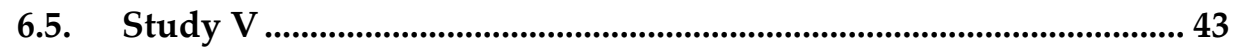

6.6. Summary of the main findings............................................................... 44

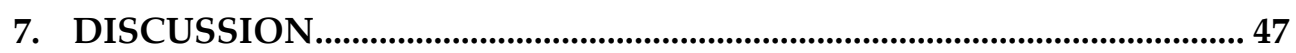

7.1. Prevalence of alcohol consumption before and during pregnancy ....................................................................................................... 47

7.2. Predictors of drinking during pregnancy ........................................... 50

7.3. Prevention of alcohol consumption during pregnancy .................... 53

7.4. Methodological considerations ............................................................. 57

7.4.1. Study design and approach considerations ..................................... 57

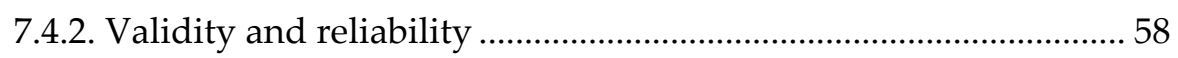

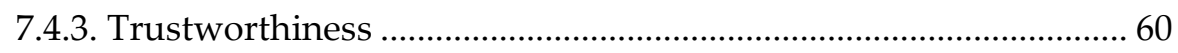

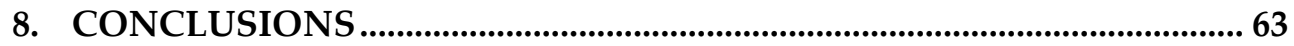

9. IMPLICATIONS FOR PRACTICE AND RESEARCH ...............................6 65

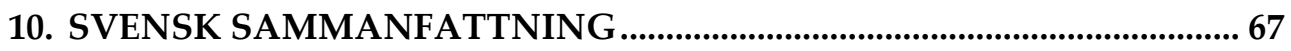

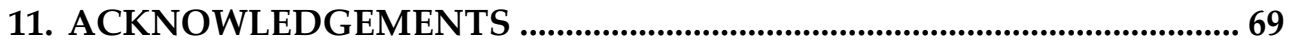

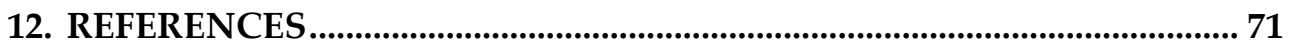

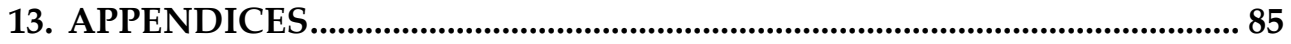




\section{KEY THEMES}

In this section the three key themes recurring in the thesis are described. The themes are described in the way they are used in the thesis.

Prevalence: In epidemiology, prevalence is the proportion of a population with a particular condition at given point of time, typically a disease or risk factor (Krug, 2008). In this thesis, the prevalence of alcohol consumption before and during pregnancy is studied.

Predictor: The term predictor or predictor variable refers to variables used to explain the outcome of a dependent variable. Other terms used for these variables are explanatory variables or independent variables (Darlington, 2005). In this thesis the term predictor refers to variables used to explain variations in alcohol consumption during pregnancy.

Prevention: The term prevention means to keep something from happening. The goal of prevention is to reduce diseases, disability and other forms of human suffering (Wallace, 2006). Prevention of fetal alcohol exposure is assessed and discussed in the thesis. The concept is further described in section 4.1. 


\section{ABSTRACT}

It is well established that fetal alcohol exposure can disturb the development of the fetus and cause a range of effects for the affected child. However, research on the effects of exposure to lower levels is inconclusive and the subject is debated. Based on the precautionary principle women in many countries, Sweden included, are advised to maintain total abstinence throughout pregnancy. Regardless, studies have shown that a significant proportion of women consume alcohol around conception and throughout pregnancy. The overall aim of this thesis was to generate knowledge about the prevalence, predictors and prevention of alcohol consumption among women before and during pregnancy.

The aim was addressed in five studies using several datasets and methods. A systematic review of the international literature was undertaken to identify predictors of alcohol consumption during pregnancy (Study I). Questionnaires to midwives were used to investigate the alcohol-preventive work in antenatal care in Sweden (Study II). Questionnaires were also used to gather data on alcohol consumption before and during pregnancy from pregnant women across Sweden and from women who had given birth to a child in one area of Sweden (Study III and IV). Focus group interviews were used to assess nonpregnant women's voices on alcohol consumption and pregnancy in Sweden (Study V).

Taken together the results from the studies showed that alcohol consumption was common among women of childbearing age in Sweden (Study III-V) and that there were social expectations for women to drink (Study V). During pregnancy, the expectation was the opposite, as pregnant women were expected to abstain from all alcohol consumption (Study V), which is in line with the total abstinence recommendation from antenatal care. The national 'Risk Drinking Project' led to revised alcohol-preventive routines in Swedish antenatal care, including screening of all pregnant women for hazardous alcohol use in the year preceding pregnancy, an important predictor of drinking during pregnancy (Study II). A great majority of pregnant women and new mothers reported abstinence from alcohol after pregnancy recognition (Study III and IV), yet the level of reported alcohol consumption during pregnancy appeared to be affected by formulation of the question (Study IV). Factors associated with more drinking during pregnancy in 
Sweden were: living in a major city, older maternal age, tobacco use, low social support, stronger pre-pregnancy drinking habits and stronger social drinking motives (Study III). In the international research, pre-pregnancy drinking habits, exposure to abuse or violence, high income or social class and positive screen for dependence were the factors most consistently reported to be associated with more drinking during pregnancy (Study I). Women of childbearing age were uncertain about the potential effects of drinking in the period around conception and the social expectations to abstain did not seem to be as strong in this period as after pregnancy recognition (Study V). A majority of women reported having reduced their alcohol consumption only after they became aware that they are pregnant, meaning that they could have been dinking for several weeks in early pregnancy (III). 


\section{LIST OF PAPERS}

The thesis is based on the following papers. Published papers are reprinted with permission from the copyright holders.

I. Skagerström J, Chang G, Nilsen P (2011). Predictors of drinking during pregnancy: a systematic review. Journal of Women's Health, Vol. 20 (6): 901-913

II. Skagerström J, Johansson AL, Holmqvist M, Envall E-K, Nilsen P (2011). Towards improved alcohol prevention in Swedish antenatal care? Midwifery, Vol. 28: 314320

III. Skagerström J, Alehagen S, Häggström-Nordin E, Årestedt K, Nilsen P (2013). Prevalence of alcohol use before and during pregnancy and predictors of drinking during pregnancy: a cross sectional study in Sweden. BMC Public Health Vol. 13: 780-790

IV. Skagerström J, Festin K, Blomberg M, Nilsen P. Asking about alcohol consumption during pregnancy: how prevalence rate is affected by the formulation of the question. Manuscript.

V. Skagerström J, Häggström-Nordin E, Alehagen S. The voice of non-pregnant women on alcohol consumption during pregnancy: a focus group study among women in Sweden. Submitted. 


\section{INTRODUCTION}

More than one hundred years ago, Dr William Sullivan reported scientific evidence suggesting that alcohol has a toxic effect on developing embryos (Sullivan, 1899). The work was conducted at a time when degenerative features were thought to be passed on from parents to children, ultimately eliminating the family line (Sanders, 2011). Alcoholism among fathers and mothers was viewed as equally important to their children's health. Sullivan decided to study the features of babies born to alcoholic mothers "to illustrate the mode in which the maternal intoxication appears to have reacted on the development of the offspring" (Sullivan, 1899, p. 490). He reported that the rates of stillborn babies and infant mortality were more than twice as high among alcoholic mothers compared to nonalcoholic mothers.

At that time, Sullivan's work was not well distributed or acknowledged, and it took about 70 more years before Jones and colleagues published a study describing the relationship between alcohol consumption during pregnancy and prenatal growth deficiency and developmental delay, a syndrome they called Fetal Alcohol Syndrome, FAS (Jones \& Smith, 1973). Since the publication of the 1973 article, the research on neurodevelopmental effects of exposure to alcohol in utero has grown rapidly.

The association between embryonic and fetal exposure to alcohol and numerous adverse health consequences has been well documented (Allebeck \& Olsen, 1998; McGee Petrenko, 2011). There is general agreement that fetal exposure to high doses of alcohol is harmful and can cause lifelong problems. The American Academy of Pediatrics (2000) has pointed out alcohol consumption during pregnancy as one of the leading preventable causes of birth defects, intellectual disability and neurodevelopmental disorders in the US.

The effects of exposure to small to moderate doses of alcohol are currently debated. While even small amounts have been reported to cause adverse pregnancy outcomes and neurobehavioral effects in some studies (NyboAndersen et al., 2012; Sayal et al., 2007; Sood et al., 2001), other studies have found no negative effects (Kelly et al., 2012; Kesmodel et al., 2012; Underbjerg et al., 2012). No safe level of alcohol consumption during pregnancy has been 
possible to establish, and the precautionary principle promoting total abstinence during pregnancy prevails in recommendations from authorities in many countries, such as the US, Canada, Australia, Iceland, France, Norway and Sweden.

The present thesis was conceived against the backdrop of historically high levels of alcohol consumption among Swedish women during the past decades. There has been a recent reduction in the total amount consumed, but a majority of women of fertile age still drink alcohol (Public Health Agency of Sweden, 2014; Ramstedt, 2010), and a tendency for sex convergence, i.e. lower consumption among men and higher among women, has been noted (Källmen et al., 2015). In recent decades, the share of women who are employed has increased. Many couples in Sweden postpone childbearing until both have stabile work situations, often after years of education (Danielsson \& Sundström, 2006) This has led to an increased mean age among Swedish women having their first child. In 2012 the mean age of first-time mothers was about 28 years, compared to 24 years in 1973 (Swedish National Board of Helath and Welfare, 2013). Many women have been drinking alcohol for several years when they enter their first pregnancy. This development has raised concerns regarding the prevalence of alcohol consumption during pregnancy. The thesis is comprised of five studies that address various aspects of the prevalence, predictors and prevention of alcohol consumption during pregnancy. 


\section{BACKGROUND}

In this chapter, information on alcohol and alcohol consumption during pregnancy is reviewed. Further the Swedish context concerning antenatal care and guidelines on drinking during pregnancy is presented. Finally the rationale for the thesis is provided.

\subsection{Alcohol culture}

Alcohol consumption has been given a high cultural value in most European societies and is integrated into many cultural practices (Järvinen \& Room, 2007). Europe accounts for the highest levels of alcohol consumption among the world regions (WHO, 2014). Amounts and patterns of drinking as well as preferred beverages among inhabitants in different societies have long been known to differ across countries and societies (Devaux, 2015; Järvinen \& Room, 2007). A number of factors, such as sociodemography, economic development, religion and preferred beverage type, are thought to interact, causing a difference in alcohol use between regions of the world (WHO, 2014). A sociocultural perspective, in which individuals' development and behavior are thought to be affected by norms and values within a culture (Vygotsky, 1978), has been used to explain the fact that drinking patterns and alcohol-related problems differ across countries and subpopulations.

Several classifications of drinking cultures have been proposed. One way is to define drinking cultures based on the beverage most commonly consumed; wine-cultures, beer-cultures and spirit-cultures are all prevalent in different parts of Europe. Another categorization traditionally used in Europe is the wet and -dry dyad. In wet alcohol cultures, there is a more frequent use of alcohol but in small quantities, while dry drinking cultures are characterized by low consumption on the aggregated level, but frequent binge drinking (i.e., consuming a large amount of alcohol in a limited period of time)(Room \& Mäkelä, 2000). However, as the alcohol consumption in Europe is changing and drinking patterns become more alike across cultures, these classifications have lost part of their purpose. 
Drinking culture is often described and assessed in terms of norms and attitudes towards drinking in a society (Makela, 1984). Norms have been found to vary between sub-groups of a population, constituted by for example by gender, social class and age (Devaux, 2015; Härkönen, 2013)

\subsection{Alcohol consumption in Sweden}

Alcohol is an integrated part of life in Sweden. About 90\% (92\% men and 88\% women) of the adult population report that they consume alcohol (HelmerssonBergmark, 2001). Traditionally, Sweden has been classified as a dry country, i.e. as having a high share of abstainers, relatively low alcohol consumption on an aggregated level, but numerous of occasions with heavy drinking (Järvinen \& Room, 2007). However, several studies have shown that this is changing toward a more evenly distributed alcohol intake. The consumption of wine and beer has increased, and hard spirits consumption has decreased (The Swedish Council for Information on Alcohol and Other Drugs, 2012). At the same time as drinking on weekdays has become more common, binge drinking on weekends is still prevalent. This indicates that the new way of drinking has not replaced the old drinking patterns, but the two have rather been combined (Bernhardsson, 2014; Leifman, 2002)

Although there has been a reduction in alcohol consumption in Sweden over the past decade, the consumption levels are still high when viewed in a longer perspective. Before Sweden's entrance into the European Union in the mid1990s, the total amount of consumed alcohol was about 8 liters of pure alcohol per inhabitant over 15 years of age and year. In the following years, consumption increased until reaching the peak level of over 10 liters in 2004. In 2012, the total alcohol consumption had decreased to about 9 liters of pure alcohol per inhabitant over 15 years of age (The Swedish Council for Information on Alcohol and Other Drugs, 2012; Ramstedt, 2013). The consumption is skewed, with about $10 \%$ of consumers accounting for about half of the alcohol intake (Mustonen et al., 2007; Raninen et al., 2014). Also, women drink about half the amount of men (Helmersson-Bergmark, 2001; Ramstedt, 2010). During the $20^{\text {th }}$ century, there has been an increase in the share of young women who report being abstainers (Raninen et al., 2014). However, four out of five girls in year 11 (aged about 18 years) have tried alcohol at least once, and almost one third of women aged 16-29 years report having been involved in 
binge drinking during the past 30 days (The Swedish Council for Information on Alcohol and Other Drugs, 2012).

\subsection{An international perspective on alcohol consumption before and during pregnancy}

Alcohol consumption during pregnancy has been investigated in numerous studies conducted across the world. The reported occurrence varies greatly depending on the population studied. For example, a prevalence rate of less than $5 \%$ has been reported in Japan (Tamaki et al., 2008), about $8 \%$ in the US (CDC, 2012) and 20\% in Russia (Balachova et al., 2012). A higher share of pregnant women consuming alcohol has been found in European countries such as Spain and Norway, where occurrence of $23 \%$ has been reported (Alvik et al., 2006b; Palma et al., 2007); the corresponding figure for Denmark is $45 \%$ (Nybo-Andersen et al., 2012) and for France 47\% (Malet et al., 2006). It should be noted that these studies have used different cut-offs for drinking, such as any drinking at all (Balachova et al., 2012; Nybo-Andersen et al., 2012; Palma et al., 2007), drinking more than 1 standard drink (SD) (Tamaki et al., 2008) or more than one SD in the past 30 days (CDC, 2012). Further, the data collection methods differ between the studies, some using telephone interviews (CDC, 2012; Nybo-Andersen et al., 2012), others questionnaires (Alvik et al., 2006a) and face-to-face interviews (Balachova et al., 2012; Malet et al., 2006; Palma et al., 2007). Other methodological difference are the study sample and the time point for data collection. Furthermore, social and cultural norms regarding drinking during pregnancy may impact women's reporting toward giving answers that are socially acceptable in the respective cultures.

A number of studies have been conducted to investigate alcohol consumption among pregnant women in specific areas in Sweden. In one study conducted in Stockholm, the capital of Sweden, 30\% of pregnant women were found to consume alcohol during pregnancy, most of them once a month or less often (Göransson et al., 2003). In another study conducted in Uppsala, the fourth largest city in Sweden, $12 \%$ of pregnant women reported alcohol consumption (Comasco et al., 2012). Three studies conducted in Linköping, another mediumsized Swedish city, have reported that $6 \%$ of women continue to use alcohol during pregnancy (Nilsen et al., 2010; Nilsen et al., 2008; Nilsen et al., 2012b). For consumption over 70 grams per week or 60 grams per occasion, prevalence 
figures of $15 \%$ and $17 \%$ have been reported in early pregnancy, including the period before pregnancy recognition (Goransson et al., 2006; Magnusson et al., 2005).

\subsection{Effects of alcohol consumption during pregnancy}

Alcohol is a known teratogen, i.e. an agent capable of disturbing the development of an embryo or fetus and cause malformations. Trough disturbance of the fetal development alcohol can cause a spectrum of adverse effects ranging from minor to severe. The most profound harm is disrupted development of the brain leading to neurobehavioral effects including cognitive and behavioral impairments. Impact on the developing brain can occur in all three trimesters (Clarke \& Gibbard, 2003; Riley et al., 2011). The effects of alcohol exposure in utero is dependent of dose, timing of exposure, maternal nutrition (Riley et al., 2011), and genetic factors (Warren \& Li, 2005). Disorders caused by alcohol exposure in utero are classified under the umbrella term Fetal Alcohol Spectrum Disorders (FASD)(Sokol et al., 2003).

Although alcohol exposure is harmful during all stages of pregnancy the consequences vary. Animal studies have shown that the central nervous system (CNS) is susceptible to insult from maternal alcohol intake as early as the third week of gestation (Sulik, 2011). Alcohol exposure on gestation days 1-6 in rodents has been found to not only increase the risk of prenatal mortality, but also increase the risk of, for example gestational growth and malformations (Padmanabhan \& Hameed, 1988). This indicates that alcohol exposure in very early pregnancy, before the egg is implanted, can be teratogenic as well as lethal, at least to mice embryos (Stratton et al., 1996). High levels of alcohol consumption in early pregnancy have been associated with increased risk of spontaneous abortion (Bailey \& Sokol, 2011). The evidence for smaller amounts is uncertain (Henderson et al., 2007), but a few studies have found that the risk of spontaneous abortions increases gradually with dose of alcohol exposure in early human pregnancy (Nybo-Andersen et al., 2012; Windham et al., 1997). In the study by Andersen and colleagues, no increased risk was found after week 16 , implying that the fetus is most vulnerable to alcohol exposure during early pregnancy (Nybo-Andersen et al., 2012). The major organs form during the first 
trimester, making this period critical. Exposure to alcohol during early pregnancy has been found to cause dysmorphic facial features evident in FAS (Coles, 1994; Ernhart et al., 1987; Graham et al., 1988). Further, alcohol consumption in the first trimester has been associated with increased risk of preterm delivery and growth impairment even at relatively small amounts of exposure (Nykjaer et al., 2014). However, these findings have been contradicted by other studies. For example in a prospective multicenter cohort study, no altered risks for preterm delivery or growth impairment were found among women consuming alcohol in early pregnancy (McCarthy et al., 2013).

\subsubsection{Binge drinking}

Binge drinking, (also referred to as heavy episodic drinking) often defined as consumption of 48 grams of pure alcohol during a short period of time for women, or 60 grams for men, is commonly reported early pregnancy. For example in Norway and Denmark, about $25 \%$ of pregnant women report binge drinking sometime during pregnancy, most often before pregnancy recognition (Alvik et al., 2006b; Strandberg-Larsen et al., 2008). In a Canadian study, 11\% of pregnant women reported binge drinking in early pregnancy before pregnancy recognition (Tough et al., 2006). There are conflicting results regarding fetal effects after exposure to the high blood concentrations of alcohol caused by binge drinking. Data from animal studies summarized in a review show that exposure to high peak alcohol levels equivalent to binge drinking result in more behavioral impairment in offspring than does exposure to the same amount over a longer time period (Conover \& Jones, 2012). In the same review, it is found to be harder to assess the evidence from studies on humans. An earlier review of binge drinking during pregnancy in humans did not find any consistent evidence of adverse effects. Although increased risk of, for example, low birth weight was found in some studies, the results were hard to interpret due to methodological differences and weaknesses of the individual studies (Henderson et al., 2007). However, although not conclusive there are results pointing at increased risk for various adverse effects, such as lower birth weight, heart defects, and behavioral problems, related to exposure to high concentrations of alcohol. As these results are in line with findings from animal studies, caution is recommended for women who are or might become pregnant (Conover \& Jones, 2012). 


\subsubsection{Small to moderate amounts}

The teratogenic effect of drinking small to moderate amounts of alcohol is currently debated. The issue is complex, because there are a large number of outcomes that may be affected, and several factors in addition to dose of consumption may influence the outcome, such as timing and pattern of exposure. Single studies show diverse and contradicting results. For example, 5-year-old children whose mothers had been drinking 1-2 glasses of alcohol/week during pregnancy had fewer behavioral difficulties and better results on cognitive tests than did children whose mothers abstained from alcohol throughout pregnancy (Kelly et al., 2012). Similarly, 14-year-old children whose mothers consumed small to moderate levels of alcohol during early pregnancy were found to have a decreased risk of behavioral problems compared to peers with abstinent mothers (Robinson et al., 2010). These and other studies showing J- or U-shaped curves, implying that consuming small amounts of alcohol could be beneficial, are contradicted by other studies showing effects such as higher risk of spontaneous abortions (Nybo-Andersen et al., 2012; Skogerbø et al., 2012) or by studies that are unable to show any significant associations in either direction (O'Leary et al., 2009; O'Leary \& Bower, 2012; Sayal et al., 2013; Underbjerg et al., 2012).

In their extensive review of reviews, meta-analyses and single studies investigating effects of low doses of alcohol exposure, $\mathrm{O}^{\prime}$ Leary and Bower argue that there are many difficulties and limitations in study design that can explain some of the contradicting results (O'Leary and Bower 2012). Classification of alcohol consumption is one such limitation, as the peak alcohol level may be more important than the total amount, i.e. drinking three glasses on one occasion may have a different impact on development than drinking three glasses over a week. Also, as different developmental processes occur at different time points in pregnancy, the sensitivity of the fetus vary with the exact timing of the exposure. Unmeasured or residual confounding factors are another difficulty mentioned. Taken together, dose, pattern and timing of exposure as well as potential confounders are difficult to measure accurately, which explains why risks of fetal effects are hard to establish (O'Leary \& Bower, 2012). The authors of the review conclude that although there is no strong evidence of harm with low levels of alcohol exposure, moderate levels (70 grams of alcohol per week) have been found to increase the risk of behavioral problems among children. With such a small margin, the safest option is to abstain (O'Leary \& Bower, 2012). 
Further, individual biological factors contribute to the difficulties in determining the harm caused by low doses, as exposure to the same amount can have diverse effects. In a study on the impact of alcohol exposure in utero, Lewis and colleagues found that consuming 1-6 standard drinks a week could have a negative impact on children's IQ at age 8. However, effects of alcohol exposure on IQ were only found among children with specific genetic variants in alcohol metabolizing genes. Among children with other genetic variants, no effects were detected (Lewis et al., 2012). This indicates that exposure to small to moderate amounts of alcohol can affect brain development depending on the fetus's ability to metabolize alcohol.

\subsection{Fetal Alcohol Syndrome (FAS) and Fetal Alcohol Spectrum Disorder (FASD)}

The most severe birth defect caused by fetal alcohol exposure is Fetal Alcohol Syndrome (FAS). FAS was first described in the 1970s, when Jones and Smith published a study in which they described a specific pattern of physical anomalies and reduced birth size among the newborn babies of alcoholic mothers. They also described defects in the central nervous system that caused cognitive and behavioral problems. The authors called the characteristic anomalies fetal alcohol syndrome (Jones \& Smith, 1973). Basically the same symptoms as those described by Jones and Smith are still used as criteria to diagnose FAS today. A number of slightly different guidelines for diagnosing FAS have been presented. According to some schemata, documented exposure to alcohol during pregnancy is required to establish the diagnosis. Otherwise, all schemata include symptoms from three categories that should be present in order to diagnose FAS (Barrow \& Riley, 2011):

- Pre- and/or postnatal growth impairment. This is defined as pre-or postnatal height or weight, or both, below the tenth percentile.

- Facial features. The principal facial features include smooth philtrum, small upper lip, and small eye fissures.

- Anomalies of the central nervous system (CNS). This category includes cognitive impairment, developmental delays, and problems with learning, attention, hyperactivity and social skills. 
Prenatal exposure to alcohol does not always result in all symptoms required for the diagnosis of FAS. For example, a person with confirmed exposure may experience CNS symptoms and growth impairment, but no facial features. Several terms have been used to describe different conditions caused by alcohol exposure in pregnancy but not diagnosed as FAS. The terms Partial FAS (pFAS), Alcohol-Related Birth Defects (ARBDs) and Alcohol-Related Neurodevelopmental Disorder (ARND) are all used (Stratton et al., 1996). As prenatal alcohol exposure can cause a range of bio-psychosocial effects, the term fetal alcohol spectrum disorder (FASD) is used as an umbrella term covering all effects caused by prenatal alcohol exposure (including FAS, pFAS, ARBDs and ARND). Thus a person with FASD can suffer from growth impairment, problems of the CNS, heart, eyes, kidneys and so forth or a combination of problems.

The true occurrence of FAS and FASD in the world is unknown. Several attempts have been made to investigate the prevalence of FAS through the use of surveillance systems, studies in prenatal clinics and certain referral clinics. Although high prevalence rates have been reported for selected communities, the often-cited estimated prevalence rate for the general population in the US is 0.2-1.5 per 1000 children (CDC, 1995; CDC, 1997). In Sweden, Olegård and colleagues conducted a prevalence study in 1979 reporting a prevalence of FAS of 2 per 1000 children (Olegård et al., 1979). However, figures from the Swedish National Board for Health and Welfare show only 37 persons diagnosed with FAS during the 10-year period 2001-2010, which implies that the syndrome is underdiagnosed (Rangmar, 2013). Underdiagnosing and underreporting of FAS have been established in other settings (Abel \& Sokol, 1987; Clarren et al., 2001).

In recent years, active case ascertainment in schools has been used to assess the prevalence of FAS and FASD in selected communities in the US, Croatia, Italy and South Africa. This method involves screening, targeted dysmorphological examinations and cognitive and behavioral testing of school children. The studies using this method have found rates of full FAS at 6-9 per 1000 in the US (May et al., 2014), 17 per 1000 in Croatia (Petkovic \& Barisic, 2013), 4-12 per 1000 in Italy (May et al., 2011), and 59-91 per 1000 in South Africa (May et al., 2013). The rates for FASD were 24-48 per 1000 in the US (May et al., 2014), 23-63 per 1000 in Italy (May et al., 2011), and average figures of about 135-207 per 1000 in South Africa (May et al., 2013). 
According to May and Gossage (2011), cultural variations in alcohol consumption patterns can explain the higher ratio of severe damages (FAS) in South Africa compared to in, for example, Italy. In South Africa the drinking norm includes binge drinking on weekends. Italy, on the other hand, has the lowest binge drinking rates and normative drinking includes moderate consumption with meals.

\subsection{Alcohol-preventive work in Swedish antenatal care}

Antenatal care provides an opportune setting to influence pregnant women's alcohol consumption. In Sweden antenatal care has been free of charge since the 1930s. These free visits contributed to an expansion of the antenatal care system, and at the present time virtually all pregnant women visit antenatal care. Antenatal care aims to promote good sexual and reproductive health in the population. This should be achieved through actions that reduce risks and morbidity, for mothers and babies, during pregnancy, childbirth and infancy (Berglund, 2008). The mandate for antenatal care includes medical examinations, psychosocial support and health education.

For a normal pregnancy, a so-called basic medical program is followed. The content of the basic program can vary slightly between different county council districts, but usually includes about eight or nine visits with a midwife for a woman expecting her first child. In addition to the medical program, psychosocial and lifestyle issues shall be addressed throughout the pregnancy (Strevens, 2008).

Swedish antenatal care played an important role in the Risk Drinking Project (RDP) launched by the Swedish Government in 2004. The vision of the project was to make questions concerning alcohol consumption a natural part of everyday healthcare. To reach the vision, a goal was formulated aiming for health care personnel to be active in bringing up the question of alcohol with patients. An extensive education and information intervention directed at staff in antenatal care, child health care, primary health care and occupational health services was launched to reach the overarching goal. For antenatal care, a specific goal was to improve midwives' knowledge about how alcohol 
influences the fetus and parenthood. Other goals were to improve knowledge on identification of hazardous drinking behavior among pregnant women and approaches to talking about alcohol with future parents.

In association with the RDP, a new work routine was implemented in Swedish antenatal care. The new routine included screening of all pregnant women for alcohol use before pregnancy and provision of information on effects of alcohol consumption during pregnancy to all women, independent of the screening results. One part of the information given consisted of booklets handed out to pregnant women to be read at home. The booklet "A good start" was published by the Swedish National Institute of Public Health (FHI) in 2009, and the booklet "Advice about food for you who are pregnant" was published by the Swedish National Food Administration (SLV) in 2008. The information in both booklets is also available online.

In a critical discourse analysis of the message given in the booklets, Törrönen and Tryggvesson (2015) concluded that in the booklets the responsibility for the health of the fetus is placed solely on the mothers. In both campaigns, uncertainty regarding consumption of low doses is mentioned, this uncertainty is associated with danger, and advice to abstain totally from alcohol is given (Törrönen \& Tryggvesson, 2015). A similar study examining public health campaigns against drinking during pregnancy in Sweden, Denmark, Finland and Norway was conducted by Leppo and colleagues (2014). They argued that it is not explicitly stated in any of the materials handed out to pregnant women in the four countries that there is no indisputable scientific evidence of harm from low doses of alcohol consumed during pregnancy. Rather the message in the materials was simplified and the uncertainty regarding low doses was removed in favor of a clear message encouraging total abstinence (Leppo et al., 2014).

\subsection{Rationale for the thesis}

In summary, many women of fertile age consume alcohol. A significant share of women report consumption at hazardous levels. It has been suggested that alcohol exposure during pregnancy, apart from FAS, is a major cause of neurodisability, affecting up to $1 \%$ of all children. However, as evidence of harm caused by exposure to small amounts is currently insufficient, it is not possible to determine whether or not this is accurate (Gray et al., 2009). In light of this 
uncertainty, authorities in Sweden advocate the precautionary principle and recommend total abstinence to pregnant women. Despite these recommendations, there have been reports that several women consume alcohol while pregnant. However, reported prevalence rates have varied to a great extent between different studies. This thesis is based on the premise that more knowledge is needed concerning alcohol consumption among pregnant and non-pregnant women of fertile age. Specific aspects that require further investigation include prevalence in a national sample, factors associated with drinking during pregnancy, preventive routines implemented in antenatal care as well as knowledge and thoughts pertaining to alcohol consumption during pregnancy among women who are not pregnant. 



\section{AIM OF THE THESIS}

The overall aim of the thesis was to generate knowledge about prevalence, predictors and prevention of alcohol consumption among women before and during pregnancy. The aim was addressed in five studies, with the following objectives:

I. To identify predictors of alcohol use during pregnancy documented in previous research.

II. To investigate alcohol-preventive work in antenatal care in Sweden, including professional education among midwives, alcohol-preventive practices, and knowledge concerning identification of pregnant women with hazardous alcohol use and the health risks associated with alcohol use.

III. To investigate alcohol use before and during pregnancy and predictors of alcohol use during pregnancy in Sweden.

IV. To compare reported alcohol consumption during pregnancy among women asked explicitly about drinking after pregnancy recognition compared with women asked about drinking during pregnancy without stating whether the time before recognition should be included.

V. To explore non-pregnant women's voices concerning alcohol consumption and its relation to pregnancy. 



\section{CONCEPTS AND THEORIES}

In this chapter concepts and theories used in the studies are described. Two theoretical approaches to behavior change used to explain the results from individual (pregnant and non-pregnant) women are described. Further, one organizational-level theory, used to discuss results from the study conducted on midwives in antenatal care, is described

\subsection{Prevention and promotion}

The term prevention means keeping something from happening. Prevention is traditionally described in terms of primary, secondary and tertiary prevention. The classification into primary and secondary prevention was proposed by a working group under the Commission on Chronic Illness in 1957 and tertiary prevention was added later (Gordon, 1983). In this classification, primary prevention refers to practice that occurs before a person has developed a disease in the first place, or originally prior to the biological origin of a disease. Secondary prevention refers to practice after disease recognition, but before occurrence of any severe disability or suffering. Tertiary prevention is performed to prevent deterioration after suffering or disability has occurred.

The use of a classification of prevention has spread from the area of disease prevention to mental health and public health campaigns. In these disciplines, the biological origin of a disease is not always of relevance, nor is it always definite. For example, when discussing prevention of FASD, it is difficult to determine when FASD begins. Suggested primary preventive strategies for FAS are for example education on FAS and effects of fetal alcohol exposure offered to women of childbearing age and their partners. Suggested secondary preventive strategies for health care professionals are aimed at reducing the severity and duration of maternal alcohol consumption. These strategies involve counseling women with identified alcohol consumption during pregnancy on effects on the fetus and on the benefits of reducing alcohol intake at any time during pregnancy (Alberta medical Association, 2003). For tertiary prevention aimed at reducing complications caused by FAS, strategies such as diagnose and programs designed for children with FASD and their caregivers as well as contraceptive counselling and dependence treatment for mothers (to 
prevent future alcohol exposed pregnancies) have been suggested (Alberta medical Association, 2003; Streissguth \& Grant, 2011).

Another classification of prevention has been suggested by Gordon (Gordon, 1983). Preventive measures are classified on the basis of the population group the preventive intervention is intended to address. Prevention aimed at the general public is called universal prevention. Prevention intended for a subgroup of the population is called selective prevention. Prevention aimed at individuals who have been found to be at high risk for the intended problem is called indicated prevention. In this classification, prevention is only applied to persons who are not justified by current problems. This means that what is called tertiary prevention is not seen as a form of prevention (but rather treatment), and these types of interventions are thereby not included in the classification (Gordon, 1983). Examples of FAS prevention using Gordon's classification are described by Stratton (Stratton, 1996). For universal prevention, public education aiming at a public understanding that alcohol consumption during pregnancy is hazardous is mentioned. The target population for selected preventive intervention may be women of childbearing age who drink alcohol and their partner. Suggested interventions are screening for hazardous alcohol use/abuse, brief interventions and referral to formal dependence treatment. The target population for indicated preventive intervention is suggested to be women who might become pregnant or are pregnant and who consume alcohol at a high level as well as women who have previously given birth to children with FASD. Suggested interventions include treatment for alcohol abuse or dependence (Stratton, 1996).

Health promotion is another concept closely related to prevention. At the first international conference on health promotion held in Ottawa in 1986, the concept of health promotion was established (WHO, 1986). Health promotion is described as the process of increasing the health status of individuals and communities. As many determinants of health are environmental, social, and economic and thus external to the individual, health promotion aims at enabling people to increase control over their health (Ewles, 2003). Health education programs on alcohol as well as contraception, for example in the schools, can be seen as health-promoting activities because they are not only designed to prevent ill-health, but also to improve health (Ewles, 2003). That is, in contrast to primary or universal prevention aimed at decreasing alcohol exposure in pregnancy, health-promoting activities do not have this explicit aim, although the outcomes may be identical. 
In Study II, several of the questions concern alcohol-preventive work in antenatal care. Further, discussions on prevention using the two classification schemes are found in Study III and V. Improvement of preventive interventions has also been the long-term aim of several of the studies and will be further examined in the discussion chapter of the thesis.

\subsection{Social-cognitive theories of behavior change}

Social cognitive theories are theories explaining (health) behavior at the individual or intrapersonal level. That is, the theories propose that behavior is influenced by psychological and social determinants (Conner, 2005). There are several social cognitive theories, including Self Determination Theory (used to understand the results in Study II), Social Cognitive Theory and the Theory of Planned Behavior (briefly used to interpret the results in Study V). Key concepts for these theories include the notion that cognitions mediate behavior and that, for a behavior change to occur, knowledge is necessary, but not sufficient. Social influence, motivation and skills are other factors that influence behavior

In the Theory of Planned Behavior, behavioral intention is the most important predictor of behavior. Behavioral intention, in its turn, is influenced by attitudes toward performing the behavior, subjective norms, i.e. beliefs about what other persons who are important to the individual think about the behavior, and perceived behavioral control, i.e. the individual's beliefs about his/her ability to control the behavior (Ajzen, 1988).

Social Cognitive Theory, which evolved from social learning theory, asserts that individuals learn not only from their own experiences, but also from observing others and benefiting from others' actions. Based on the outcome of a behavior for another person, an individual may decide to behave or not to behave in that specific manner. Motivation and behavior are argued to be founded on environmental and behavioral expectancies as well as self-efficacy (Bandura, 1986). Environmental expectancy is the expectancy of what outcome will occur if a behavior is not changed, for example, the perceived harmfulness of exposing a fetus to alcohol. Behavioral expectancies are expectancies concerning what outcomes, both physical and regarding social reactions, a behavior change may 
result in. That is, if both social reactions to cutting down drinking and physical reactions to reduced consumption are thought to be positive, there is an increased chance of behavior change. Behaviors that fulfill social norms will be met with positive social reactions, while behaviors that violate norms will be met with negative reactions (Bandura, 1998). Self-efficacy is the level of belief in one's own ability to make a behavior change. An individual who believes it will be easy to cut down drinking is more likely do so than an individual who does not believe in his/her on capability to reduce alcohol consumption.

Self-Determination Theory focuses on motivation, proposing that the quality and sustainability of a behavior depends on the type of motivation that underlies the behavior in question. On a continuum of motivation, amotivation is placed at one end and intrinsic motivation at the other. Amotivation is a state in which the individual does not intend to change the behavior; amotivation may be due to lack of competency to perform the behavior and/or lack of belief in the outcome of the behavior (similar to the concepts of Social Cognitive Theory and Theory of Planned Behavior). Intrinsic motivation is motivation that comes from within the individual; intrinsically performed behaviors are performed for the inherent pleasure of performing them. In between amotivation and intrinsic motivation on the continuum lies extrinsic motivation. Extrinsically motivated behaviors are performed to obtain some outcome other than the pure pleasure of performing the behavior. These outcomes could, for example, consist of positive social response, health benefits from performing the behavior, receiving a reward or avoiding shame (Deci, 1985; Ryan, 2000). Behaviors driven by autonomous motivation rather than controlled extrinsic motivation have been found to better predict behavior change (Conner, 2005). If a woman reduces alcohol consumption in relation to pregnancy solely because she is told to and is being monitored, her motivation is controlled. If she reduces alcohol because she experiences that the reduction is important and is consistent with her own values, her motivation is autonomous.

\subsection{Habit theory of behavior change}

Social cognitive theories help us understand how information may be processed and how it may influence behavioral intentions as well as behaviors. The first time an action is preformed, it requires cognitive planning and attention. When 
the action is repeated, it will require less planning and attention and become more and more automatic, or habitual. Recently, the role habits play in behavior change has become more recognized (Gardner, 2014). In Study III, the strength of alcohol consumption habits in the year before pregnancy was measured and assessed for its correlation with drinking during pregnancy.

Habits are described as automatic responses to contextual cues (Verplanken 2006; Lally 2010). The cue that triggers the behavior may be a preceding action, a location or an object (Aarts 1997). Habit formation takes place when a shift in cognitive control occurs from intentional to automatic processes. When a behavior is repeated in a stabile context, a cognitive shortcut is developed and a mental connection is established between a situation and a behavior (Nilsen et al., 2012a). Repetition of the behavior strengthens this connection (Lally \& Gardener 2001). By creating these cognitive shortcuts, mental capacity is released and time and energy are saved. Whereas some behaviors turn into habits quickly, others habits can take a long time to develop; there are also individual differences (Lally et al., 2010). Once a habit is formed it seems to be automatic, i.e. the behavior is performed without reflection and basically without awareness (Bargh \& Chartrand, 1999). Pregnancy itself can be seen as a change of context while alcohol consumption before pregnancy is performed in a stable context.

\subsection{Diffusion of innovations - a theory on the organizational and societal level}

There are numerous theories, models and frameworks that address the diffusion, dissemination and implementation of practices (services, programs, interventions, methods, etc.), e.g. counseling to pregnant women in antenatal care. Diffusion is the passive, untargeted and unplanned spread of new practices in organizations, communities and societies; dissemination is the active spread of new practices to the target audience using planned strategies; and implementation is the process of putting to use or integrating new practices within a setting (Greenhalgh, 2005).

The Theory of Diffusion, as described by Rogers (2005), is considered the single most influential theory in the broader field of knowledge utilization, of which implementation science is a part (Estabrooks et al., 2008). The theory has several 
components, but particularly relevant to this thesis is its description of various characteristics of the implemented practice, the so-called innovation attributes, that influence the adoption of this practice in a specific setting or environment. This aspect of the theory was used to discuss the results from Study II.

Six innovation attributes are described. Relative advantage refers to whether an innovation is found to be better than what it succeeds. Advantage can, for example, be measured in terms of quality, time efficiency or in economic terms (Wejnert 2002). Compatibility is the degree of compatibility between the innovation and the users' or organization's needs, values and beliefs. Complexity stands for the difficulty of using or understanding the innovation. Observability is the observed effects of using the innovation in the long or short term. Triability concerns the extent of which the innovation can be tested and experimented with. The final characteristic added to the theory is reinvention, by which Rogers means the degree to which it is possible for the user to change or modify the innovation for the user's needs (Rogers 2003).

Diffusion of Innovation is widely applied in the expanding field of implementation science. However, to fully account for the influences on implementation it is usually complemented with theories concerning individual practitioners' behaviors, theories regarding aggregate levels (e.g. theories concerning professions and communities of practice) and theories concerning the organizational level (Nilsen, 2015). 


\section{METHODS}

This chapter describes the five studies included in the thesis with regard to study design, setting, participants, and data sources. Data collection and analysis are described, including the details of the questionnaires and interview guide used in the studies. Ethical considerations are also addressed. Figure 1 provides an overview of the methodological approaches of the five studies.

\subsection{Study design}

A variety of approaches to data collection and data analysis were applied in this thesis to address the aims of the individual studies and the overall aim of the thesis. Quantitative and qualitative research methods were used to ensure appropriate design for each research question. The use of several study designs and data sources allowed the overall aim to be addressed from different perspectives and the knowledge (Thomas, 2003) on various aspects of alcohol consumption during pregnancy to be expanded and deepened. Quantitative design was used to quantify and assess associations between variables, while qualitative design was used to achieve understanding of a less well-researched subject, namely non-pregnant women's voices on alcohol in relation to pregnancy.

The research project started with a systematic review (Study I), aiming at investigating predictors of alcohol consumption during pregnancy identified in previous research. The review examined predictors of alcohol use found in studies conducted all around the world. Study I also provided an overview of international research in the field, which was useful when designing the other studies included in the thesis.

The systematic review was followed by a questionnaire study (Study II) directed at all midwives employed in antenatal care in Sweden. This study assessed alcohol-preventive practices and knowledge concerning alcohol and pregnancy among midwives working with antenatal care in Sweden. The assessment took place before and after the Risk Drinking Project (described in section 2.6), where education for midwives was provided and a new work 
routine was implemented in antenatal care. This study provided an understanding of the setting in which Study III was conducted and of the conditions of alcohol-preventive actions in antenatal care.

Study III was a cross-sectional questionnaire study conducted to investigate alcohol use and factors associated with drinking during pregnancy among pregnant women visiting antenatal care in Sweden. Findings on alcohol use before and during pregnancy among pregnant women gave rise to questions about reported alcohol consumption as well as potential preventive initiatives; these questions were the impetus for Study IV and V.

Study IV sought to investigate the differences in self-reported alcohol consumption during pregnancy between two groups of women that received differently worded questions. The women in group A were asked to report their alcohol consumption during pregnancy, but without stating whether or not the time before pregnancy recognition should be included. The women in group B were asked specifically to report alcohol consumption after pregnancy recognition. The results of Study IV can help explain some of the variation in reported prevalence in previous research conducted in Sweden. Taken together with the results from Study III, Study IV highlights the need for further investigation of women's thoughts regarding alcohol consumption around the time of conception.

The final study (Study V) was a focus group study aimed at exploring nonpregnant women's voices on alcohol and the relationship between alcohol consumption and pregnancy. The results from this study provide a picture of current expectations on alcohol consumption and knowledge on alcohol and pregnancy. The results should be considered when planning alcohol-preventive work and interventions to reduce fetal alcohol exposure. 
Table 1. Overview of study methods

\begin{tabular}{|c|c|c|c|c|c|}
\hline Study & Type of study & Study setting & $\begin{array}{l}\text { Population } \\
\text { and sample }\end{array}$ & Data collection & $\begin{array}{l}\text { Data } \\
\text { analysis }\end{array}$ \\
\hline I & $\begin{array}{l}\text { Systematic } \\
\text { review }\end{array}$ & $\begin{array}{l}\text { Several } \\
\text { international } \\
\text { antenatal care- } \\
\text {, delivery- and } \\
\text { ultrasound } \\
\text { clinics }\end{array}$ & $\begin{array}{l}\text { International } \\
\text { scientific } \\
\text { publications }\end{array}$ & $\begin{array}{l}\text { Extracts from } 14 \\
\text { existing } \\
\text { scientific } \\
\text { publications }\end{array}$ & $\begin{array}{l}\text { Deductive } \\
\text { analysis }\end{array}$ \\
\hline II & $\begin{array}{l}\text { Recurrent } \\
\text { cross- } \\
\text { sectional } \\
\text { study }\end{array}$ & $\begin{array}{l}\text { Antenatal care } \\
\text { centers in } \\
\text { Sweden }\end{array}$ & $\begin{array}{l}\text { All midwifes } \\
\text { working in } \\
\text { antenatal care } \\
\text { across Sweden }\end{array}$ & $\begin{array}{l}\text { Pre- }(n=974) \text { and } \\
\text { post- }(n=1108) \\
\text { intervention } \\
\text { questionnaires } \\
\text { sent to } \\
\text { midwives }\end{array}$ & $\begin{array}{l}\text { Correlation } \\
\text { and } \\
\text { regression } \\
\text { analyses }\end{array}$ \\
\hline III & $\begin{array}{l}\text { Cross- } \\
\text { sectional } \\
\text { study }\end{array}$ & $\begin{array}{l}30 \text { antenatal } \\
\text { care centres in } \\
\text { Sweden }\end{array}$ & $\begin{array}{l}\text { Pregnant } \\
\text { women } \\
\text { visiting } \\
\text { antenatal care } \\
\text { across Sweden }\end{array}$ & $\begin{array}{l}\text { Questionnaire } \\
\text { distributed at } \\
\text { antenatal care } \\
\text { clinics }(n=1574)\end{array}$ & $\begin{array}{l}\text { Correlation } \\
\text { and } \\
\text { regression } \\
\text { analyses }\end{array}$ \\
\hline IV & $\begin{array}{l}\text { Retrospective } \\
\text { comparative } \\
\text { study }\end{array}$ & $\begin{array}{l}\text { Women's } \\
\text { home, urban } \\
\text { area Sweden }\end{array}$ & $\begin{array}{l}\text { New mothers } \\
\text { in Linköping, } \\
\text { Sweden }\end{array}$ & $\begin{array}{l}\text { Questionnaire } \\
\text { sent to two } \\
\text { groups of } \\
\text { women after } \\
\text { delivery }(n=1041 \\
+933 \text { ) }\end{array}$ & $\begin{array}{l}\text { Correlation } \\
\text { and } \\
\text { regression } \\
\text { analyses }\end{array}$ \\
\hline V & $\begin{array}{l}\text { Interpretative } \\
\text { qualitative } \\
\text { study }\end{array}$ & $\begin{array}{l}\text { Public places } \\
\text { and schools in } \\
\text { small and } \\
\text { medium-sized } \\
\text { cities in } \\
\text { Sweden }\end{array}$ & $\begin{array}{l}\text { Non-pregnant } \\
\text { women of } \\
\text { fertile age in } \\
\text { south-eastern } \\
\text { Sweden }\end{array}$ & $\begin{array}{l}\text { Focus group } \\
\text { interviews } \\
(\mathrm{n}=34)\end{array}$ & $\begin{array}{l}\text { Inductive } \\
\text { thematic } \\
\text { analyses }\end{array}$ \\
\hline
\end{tabular}




\subsection{Study setting}

Study I was a systematic review comprising 14 studies conducted worldwide: 4 in the US, 4 in Europe, 3 in Australia and New Zealand, 2 in Asia and 1 in Africa. Data in the included studies were collected in antenatal care, ultrasound clinics or delivery clinics.

Study II and III were based on data collected from antenatal care centers across Sweden. For both studies, the clinics were heterogeneous with regard to location, size, and urbanity. In Study II, the data were based on questionnaires completed by midwives working at all antenatal care clinics within primary care in Sweden. In Study III, the data were collected from pregnant women visiting 30 antenatal care clinics across Sweden.

Data for Study IV were collected from new mothers registered at the largest antenatal care center in Linköping, Sweden. The questionnaires were sent home to the women, who returned them by post.

The interviews conducted for Study V were held in southeastern Sweden. Five interviews were held in a medium-sized city with a university and two interviews were held in small towns without a university. The interviews took place at easily accessible public places and schools.

\subsection{Population and sample}

The study population in Study II consisted of all midwives working in antenatal care. The baseline questionnaire was sent to 2106 midwives in 2006 and 974 questionnaires were analyzed (46\%). The follow-up questionnaire in 2009 was sent to 1796 midwives and 1108 questionnaires were analyzed (62\%). Reorganizations of antenatal care took place in some county councils between baseline and follow-up. Some units were restructured from primary care to inpatient care and where therefore removed from the study sample in 2009. On both occasions, more than $99 \%$ of the participants were female, the mean age was about 52 years, and about one third had more than 20 years practice in midwifery. 
The study populations in Study I and Study III were pregnant women. In Study I - the review - data were retrieved from published studies, which in their turn had collected data from women during pregnancy or immediately after delivery. The number of study participants included in these 14 studies ranged from 248 to 18,965; the total was 51,822. The mean age reported in the studies ranged from 22.6 to 31.9 years. Study III was based on data collected from pregnant women in Sweden who had reached their $18^{\text {th }}$ week of pregnancy. A total of 1693 women were asked to participate, and 1574 questionnaires were analyzed (response rate $93 \%$ ). $67 \%$ of the women were aged $25-34$ years, $21 \%$ were 35 years or older and $12 \%$ were 24 years or younger. A majority of the women had a university education and $80 \%$ were employed.

In Study IV, the study population comprised new mothers who had given birth 3-6 months earlier. Questionnaires were sent to two groups of women, at two points in time, 1041 out of the 1553 sent questionnaires were analyzed for group A (67\%) and 933 out of the 1476 sent questionnaires were analyzed for group B $(63 \%)$. About two thirds of the participating women had a university education, a small majority (55\%) had previous children and $98 \%$ of the women were married or cohabiting.

The study population in Study V consisted of 34 women of fertile age who were neither pregnant nor had children. The age of the women ranged from 17 to 34 years and the mean age was 23.6 years. A majority were students and about $40 \%$ had a university education.

\subsection{Data collection}

The data collection for Study I started with searching databases for relevant studies. The searches yielded 317 abstracts which were reviewed against the inclusion criteria: study participants were recruited in an antenatal care environment; data collection occurred during pregnancy or immediately after delivery; predictors for any drinking were assessed; population based orientation; published in English peer-reviewed journal; and data were collected 1999-2009. After reading the abstracts 63 articles were reviewed in full text, 14 of them matched the inclusion criteria and were included in the study. The original data extraction scheme was further developed during the analyse process to make sure all relevant data was presented in a structured way. 
Data for Study II were gathered at two time points by anonymous postal questionnaires. The baseline questionnaire was distributed in 2006, before the start of the Risk Drinking Project. The follow-up questionnaire was sent in 2009, after the project was finished and the new alcohol preventive work routine had been implemented. A reminder was sent out two weeks after the initial questionnaire and another reminder after two more weeks.

To collect data from pregnant women for Study III, 30 antenatal care centres were enrolled. Consecutive pregnant women who visited any of the included antenatal care centres for a scheduled appointment with a mid wife, had reached pregnancy week 18, and understood Swedish were invited to participate in the study. The women were given an information letter and the anonymous questionnaire by their midwife and were asked to fill it out in the waiting room. Each participating centre collected questionnaires for four weeks. If the woman declined participation her midwife asked her a few drop-out questions.

The addresses to the new mothers in study IV were retrieved from the antenatal care centre in Linköping that the women had visited during pregnancy. Within 3-6 months after delivery questionnaires were sent home to the women. The women were asked to fill out the questionnaire at home and return it in an enclosed postage prepaid envelope. A reminder was sent a few weeks after the first questionnaire was mailed.

Study V was based on seven focus group interviews. Participants were recruited from different sites such as schools, university and gym. Three groups consisted of women within school classes. Four groups were comprised by women recruited at different places. For the comprised groups snowball sampling was used. Inclusion criteria for the study were: female, age 15-35 years, not pregnant, no children and Swedish speaking. All interviews were moderated by JS and an assisting moderator took care of practical issues and took field notes. 


\subsection{Data extraction scheme, questionnaires and interview guide}

For the review - Study I - data were extracted from the included studies following a scheme developed for the study. Data on study setting and participants, study protocol and study outcomes were extracted for the following items:

- Location of the study

- Duration and period of data collection

- Number of participants and response rate

- Characteristics of participants

- Study design

- Inclusion criteria

- Alcohol measurement instrument or questions

- Measurement points

- Week of gestation

- Factors associated with drinking during pregnancy

- Factors assessed but not associated with drinking during pregnancy

For Study II, two separate questionnaires were constructed (Appendix A and B). The baseline questionnaire consisted of 25 questions, of which eleven were extracted for use in this study. Three of the questions concerned background characteristics of the respondents: sex, age and years in practice. One question concerned location of the antenatal care center among the three response options: rural area, medium-sized city and major city (Stockholm, Gothenburg, Malmo). Two questions assessed number of meetings with pregnant women per week in private and in a group situation; both had four fixed response options. The midwives' amount of continuing professional education concerning handling of hazardous alcohol consumption among enrolled women was measured using six response options, ranging from 'no education' to 'more than three days of education.' One question asked about the midwives' regular practice concerning their use of a screening instrument to assess alcohol consumption before pregnancy among their patients. If the respondents used such a questionnaire, they were asked to report its name. If they did not use any 
questionnaire, they were asked to report whether they assessed pre-pregnancy alcohol consumption in any other way or did not address this topic at all. Further, the midwives were asked about their routines for detecting a woman with hazardous alcohol consumption before pregnancy. The question had four response options: provide general information about the health consequences of alcohol, initiate a motivational interview to ensure abstinence during pregnancy, refer the woman to staff within the center, and refer the woman to staff outside the center. Two questions considered the midwives' self-estimated knowledge about the health risks associated with fetal alcohol exposure and about detection of women with hazardous alcohol consumption before pregnancy. The questions had four response options ranging from 'very good' to 'very poor.'

For the follow-up questionnaire, several questions on continuing professional education during the past three years were added. First, one yes/no question asked about participation in education during the past three years. Respondents who had not participated in any education were asked to state why and to choose one or several of four options. One question asked about amount of education in motivational interviewing (MI). Further, three questions were assessed on a 4-point agreement scale ranging from 'fully agree' to 'fully disagree.' The first concerned reasons for participation in the education and consisted of five items assessing whether the initiative came from the midwife herself or from a colleague or manager. The second was a 4-item question assessing the relevance and novelty of the education. The third was a 7-item question asking about improvements and changes in alcohol-preventive work during the past three years. Further, questions on tobacco were added (not analyzed here). Questions on requested education included in the baseline questionnaire were removed for the follow-up. From the follow-up questionnaire, 14 questions were extracted for use in Study II.

For the study on pregnant women - Study III - another study-specific questionnaire was created (Appendix C). The questionnaire contained questions on background characteristics, patient satisfaction, perceived message on alcohol from antenatal care, discussion on alcohol with midwife, alcohol consumption before and during pregnancy, drinking motives, consumption habits, tobacco use and social support. The ten generic questions and four instruments used in Study III are presented in Table 2. 
Table 2. Study variables used for Study III

\begin{tabular}{|c|c|c|c|c|}
\hline Area & Instrument & Type of questions & $\begin{array}{l}\text { Answering } \\
\text { alternatives }\end{array}$ & $\begin{array}{l}\text { No of } \\
\text { questions }\end{array}$ \\
\hline Demographics & Not relevant & $\begin{array}{l}\text { Age, education, } \\
\text { occupation, civil status, } \\
\text { previous children, } \\
\text { pregnancy week, and no } \\
\text { of antenatal care visits }\end{array}$ & $\begin{array}{l}\text { Multiple choice } \\
\text { questions with 2-7 } \\
\text { alternatives. } \\
\text { Pregnancy week } \\
\text { was open-ended }\end{array}$ & 7 \\
\hline $\begin{array}{l}\text { Alcohol } \\
\text { consumption }\end{array}$ & $\begin{array}{l}\text { Alcohol Use } \\
\text { Disorder } \\
\text { Identification } \\
\text { Test - } \\
\text { Consumption* } \\
\text { (Bush } \text { et al., } \\
\text { 1998) }\end{array}$ & $\begin{array}{l}\text { Quantity and frequency } \\
\text { of alcohol use and } \\
\text { frequency of binge } \\
\text { drinking prior to and } \\
\text { during pregnancy }\end{array}$ & $\begin{array}{l}\text { Frequency before } \\
\text { pregnancy: } 4 \\
\text { options. Frequency, } \\
\text { typical quantity } \\
\text { and frequency of } \\
\text { HED during } \\
\text { pregnancy*: } 6 \\
\text { options each }\end{array}$ & $3+3$ \\
\hline Tobacco use & Generic & $\begin{array}{l}\text { Tobacco use before and } \\
\text { during pregnancy }\end{array}$ & $\begin{array}{l}4 \text { alternatives on } \\
\text { use bef. pregnancy } \\
\text { and } 3 \text { alternatives } \\
\text { on use during } \\
\text { pregnancy }\end{array}$ & $1+1$ \\
\hline $\begin{array}{l}\text { Prepregnancy } \\
\text { alcohol habit }\end{array}$ & $\begin{array}{l}\text { Short version } \\
\text { of Self-Rated } \\
\text { Habit Index } \\
\text { (Verplanken } \\
\text { B, 2003) }\end{array}$ & $\begin{array}{l}\text { Statements assessing the } \\
\text { strength of pre-pregnancy } \\
\text { alcohol habit }\end{array}$ & $\begin{array}{l}\text { Statements } \\
\text { answered on a 4- } \\
\text { point Likert scale } \\
\text { 'agree completely' } \\
\text { to 'do not agree' }\end{array}$ & 5 \\
\hline $\begin{array}{l}\text { Drinking } \\
\text { motives prior to } \\
\text { pregnancy }\end{array}$ & $\begin{array}{l}\text { Drinking } \\
\text { Motives } \\
\text { Questionnaire } \\
\text { (Cooper ML, } \\
\text { 1992) }\end{array}$ & $\begin{array}{l}\text { Questions on coping } \\
\text { motives, social motives, } \\
\text { and enhancement motives } \\
\text { for drinking prior to } \\
\text { pregnancy }\end{array}$ & $\begin{array}{l}\text { Statements } \\
\text { answered on a 4- } \\
\text { point scale: 'almost } \\
\text { never/never' to } \\
\text { 'almost always' }\end{array}$ & 15 \\
\hline Social support & $\begin{array}{l}\text { Maternity } \\
\text { Social Support } \\
\text { Scale (Webster } \\
\text { et al., 2000) }\end{array}$ & $\begin{array}{l}\text { Support from friends, } \\
\text { family, and partner }\end{array}$ & $\begin{array}{l}\text { Statements } \\
\text { answered on a 5- } \\
\text { point Likert scale } \\
\text { ranging from } \\
\text { 'never' to 'always' }\end{array}$ & 6 \\
\hline $\begin{array}{l}\text { Time point for } \\
\text { reducing } \\
\text { alcohol intake }\end{array}$ & Generic & $\begin{array}{l}\text { When the woman ceased } \\
\text { or reduced her alcohol } \\
\text { consumption }\end{array}$ & $\begin{array}{l}4 \text { alternatives } \\
\text { (when planning } \\
\text { pregnancy, when } \\
\text { becoming aware of } \\
\text { pregnancy, after } \\
\text { conversation with } \\
\text { midwife, other) }\end{array}$ & 1 \\
\hline
\end{tabular}


* The response options for the Alcohol Use Disorder Identification test were somewhat revised for assessment of alcohol consumption during pregnancy.

In Study IV, two questionnaires were used (Appendix D and E). Both questionnaires included questions on:

- Respondent characteristics: age, education, occupation, civil status and previous children. Five multiple-choice questions with 2-7 alternatives.

- Information and advice on alcohol from antenatal care; one question on perceived advice, a multiple-choice question with four fixed options and one free-text option. Two items assessing whether the information was sufficient and easy to comprehend on a four-point agreement scale ranging from 'totally agree' to 'disagree,' plus the option 'no opinion.'

- Tobacco use before and during pregnancy; one question each assessing tobacco use before and during pregnancy. Four and three fixed response options, respectively.

- Alcohol use before pregnancy; one question asked about thoughts on reasons for declining alcohol consumption among pregnant women. A somewhat modified version of AUDIT-C (Bush et al., 1998) asking about frequency of alcohol consumption, typical quantity consumed and frequency of consuming more than 5 standard drinks. The women in group B were in addition asked to report frequency of consuming more than 4 standard drinks. All items had 5-6 fixed alternatives.

- Change in alcohol use associated with pregnancy; one question assessed when alcohol use was declined (if it was), with the response-options 'when planning pregnancy,' 'when becoming aware of pregnancy,' 'when meeting a midwife' and 'other.' One yes/no question asked whether total abstinence had been achieved after pregnancy recognition. One five-item question asked about the importance of different sources (such as information in antenatal care, media, discussions with family and friends) for changed alcohol consumption during pregnancy. The question had fixed response options ranging from 'very important' to 'not important at all.' 
In addition to these questions the women in group A were asked about social support and patient satisfaction with antenatal care. The women in group B were asked about their thoughts on the reasons for decreases in reported alcohol consumption among pregnant women in Sweden.

Importantly, the questionnaires also differed related to the wording of the question on alcohol consumption during pregnancy. In group $\mathrm{A}$, the respondents were asked to 'estimate your alcohol consumption during pregnancy,' and in group B the respondents were asked to 'estimate your alcohol consumption during pregnancy, i.e. after pregnancy recognition'. Both groups then estimated their frequency and quantity of alcohol consumption as well as frequency of drinking more than five standard drinks.

For Study V, a semi-structured interview guide was constructed (Appendix F). The interview guide was tested in two pilot groups, after which minor revisions were made. However, the stimulus material and major questions were unchanged. The pilot interviews were not included in the analyses. The guide included an opening question, introduction questions, transition questions and key questions, as suggested by Krueger and Casey (Krueger \& Casey, 2009). Areas covered in the interviews were perceptions regarding alcohol consumption in general and alcohol consumption during different stages of pregnancy. To encourage interaction (Wibeck et al., 2007) and to initiate discussions on the different areas, stimulus material in form of pictures was used. Four stimulus pictures were used. When presenting each picture, the moderator asked about the participants' first thoughts/impressions concerning the picture. Further the moderator followed up with questions on, for example, social norms related to alcohol consumption, knowledge regarding alcohol and pregnancy, habits, drinking motives, responsibility for the fetus and autonomy.

\subsection{Data analysis}

In the systematic review (Study I), the data analyses consisted of structuring and deductively compiling the information extracted according to the scheme. The methodological quality was assessed using an 8-point checklist. For the assessment of outcome, each factor that was assessed for association with drinking during pregnancy in the reviewed studies was reported separately. For each factor, the total number of studies assessing the factor was reported as 
well as the share of studies that found a positive or negative association and the share of studies that did not find any association.

In Study II, the answers to the two questions asking about the respondents' selfrated knowledge about health risks associated with drinking during pregnancy and about detection of pregnant women with risky consumption before pregnancy were combined to construct a new variable. The midwives who estimated their knowledge on both dimensions as 'very good' were categorized as the most self-efficacious midwifes. The midwives who answered the two questions in any other way comprised the comparison category, referred to as 'other' mid wives. To compare the most self-efficacious midwives with the other midwives, chi-squared tests were performed. As a second step, logistic regression was conducted to investigate the relationship between being among the most self-efficacious group and variables on characteristics, work practice and education.

It should be noted that using chi-squared tests to compare data from 2006 and 2009 is not optimal. However, no individual-level data were available, making it impossible to determine whether the baseline and follow-up groups were dependent or independent. No follow-up was planned when the baseline questionnaire was sent out, which is why a cross-sectional rather than a longitudinal design was chosen. The follow-up questionnaire was sent to the same population, but the response rates for the two data collections were only $46 \%$ and $62 \%$. Inability to identify the respondents made it impossible to know how the samples were related. However, independence between the groups was assumed as chi-squared analyses were performed. The alternative would be to present the data without any significance tests.

In Study III, the answers from AUDIT-C before pregnancy were used to create three categories of alcohol consumption: abstainers, moderate drinkers and hazardous drinkers. Women who had not been drinking any alcohol in the year preceding pregnancy were categorized as abstainers. Hazardous consumption was defined as drinking four or more standard drinks on the same occasion at least once a month and/or consuming nine or more standard drinks a week. Women who reported consumption below these cut-offs were categorized as moderate drinkers. For alcohol consumption during pregnancy two categories were created: abstainers during pregnancy and drinkers during pregnancy. The latter group consisted of all women who reported that they had engaged in drinking at least once after pregnancy recognition. This means that even women 
who drank very small amounts were categorized as drinking during pregnancy. Chi-squared test, Fishers exact test and Mann-Whitney $U$ test were used to compare abstainers, moderate and hazardous drinkers before pregnancy. Logistic regression analysis was conducted to investigate predictors of any alcohol consumption during pregnancy. Abstainers in the year preceding pregnancy were excluded from the regression model.

In Study IV, to assess whether there were any differences between group A and group B, chi-squared tests and Fisher's exact test were performed. Binary logistic regression was conducted to analyze the relationship between reported alcohol consumption during pregnancy and type of question asked. Abstainers in the year preceding pregnancy were not included in the regression analysis.

In Study V, inductive thematic analysis, as described by Braun and Clarke (Braun \& Clarke, 2006), was performed. The analysis is conducted in six steps: familiarization with the data, generating initial codes, searching for themes, reviewing themes, defining and naming themes and producing the report. In the present study, this was done by, first, transcribing and reading the data and, second, manually coding interesting segments from the data set for as many potential codes as possible and organizing them into groups. Third, the codes were analyzed and sorted into potential themes related to the aim of the study; fourth, the themes were reviewed against the data set and thematic maps were created. In step five, the core of each theme was made explicit by writing it down. The themes were also refined and given names. In the last step, we described the themes in text and chose citations to support the points of analysis.

\subsection{Ethical concerns}

The Swedish law on ethical reviews does not cover research that does not gather personal data, does not involve physical encroachment, does not aim to influence the participants in any way, and does not involve any obvious risk of harming the participants (SFS, 2003:460). Study III and V were approved through an advisory opinion given by the Regional Ethical Review Board in Linköping (reg. no. M178-09 and reg. no. 2013/93-31). No ethical approval was sought for Study I, II or IV. 
All participants involved in Study II-V were informed that their participation was voluntary and that they could discontinue their participation at any time. The data for all studies were kept in safe storage, and only the researchers involved had access to the material. Study II -IV were completely anonymous, which is why there was no risk of the participants being identified. Owing to the focus group design in Study $\mathrm{V}$, the participants could not be guaranteed confidentiality. However, at the beginning of the interviews, the participants were asked to keep information revealed during the interview within the group. In the transcribed material, the participants were given code numbers. The information on characteristics gathered was anonymous and analyzed on the group level.

Questions on alcohol consumption during pregnancy can be perceived as sensitive. For the pregnant women in study III and the new mothers in study IV, the questionnaire was totally anonymous to decrease the risk of respondents feeling that their privacy was being violated. Further, the questionnaires were completed without the presence of a midwife, and the women were free to skip any questions. The women were encouraged to contact the research group or their midwife if they had any questions regarding their questionnaire. By answering questions on alcohol consumption, the women were given an extra opportunity to reflect on their alcohol consumption, which could possibly work as an intervention in itself as a result of the "question-behavior effect" (McCambridge, 2015). Even for the non-pregnant participants in study V, discussions on alcohol and pregnancy could potentially be sensitive. The participants were encouraged to ask questions when the interviews were finished and the recorder was turned off. They were also provided the address to a website where they could read more about alcohol and pregnancy if they were interested in doing so. 


\section{RESULTS}

In this chapter the main findings from the five included studies are presented (please note that some of the results presented for Study III were not included in the original study). The findings are presented for each study separately and summarized at the end of the chapter.

\subsection{Study I - Predictors of drinking during pregnancy}

In Study I predictors of prenatal alcohol use discovered in previous research were identified and organized. Altogether 37 factors were assessed for association with drinking during pregnancy in the 14 studies included in the review. Of the investigated factors, 22 were assessed in a single study, three factors were investigated in two studies each and 12 factors were assessed in three or more studies.

Of the 12 factors assessed in three or more studies, higher pre-pregnancy alcohol consumption and exposure to abuse or violence were found to be associated with more drinking in all of the studies that assessed the relation. Higher income or social class and screening positive for alcohol problems were associated with more drinking in $80 \%$ of the studies that assessed the connection. Age was the factor that was most frequently assessed for association with drinking during pregnancy, but only 7 out of 12 studies found an association. Education was assessed in 11 studies of which 2 found lower education to be associated with more drinking, one found higher education to be associated with more drinking and 8 studies did not find an association (See Table 3). 
Table 3: Association between assessed factors and drinking during pregnancy

\begin{tabular}{lllll}
\hline $\begin{array}{l}\text { Factor associated with } \\
\text { more drinking during } \\
\text { pregnancy }\end{array}$ & $\begin{array}{l}\text { Number of } \\
\text { studies } \\
\text { assessing } \\
\text { the factor }\end{array}$ & $\begin{array}{l}\text { Positive } \\
\text { association }\end{array}$ & $\begin{array}{l}\text { Negative } \\
\text { association }\end{array}$ & $\begin{array}{l}\text { No } \\
\text { significant } \\
\text { association }\end{array}$ \\
\hline
\end{tabular}

$\begin{array}{lllll}\text { Higher age } & 12 & 7(58.3 \%) & 0 & 5(41.7 \%)\end{array}$

\begin{tabular}{|c|c|c|c|c|}
\hline Lower education & 11 & $2(18 \%)$ & $1(9 \%)$ & $8(72 \%)$ \\
\hline Smoking & 10 & $5(50 \%)$ & 0 & $5(50 \%)$ \\
\hline $\begin{array}{l}\text { Higher number of } \\
\text { pregnancies/children }\end{array}$ & 10 & $4(40 \%)$ & $1(10 \%)$ & $5(50 \%)$ \\
\hline Being unmarried & 8 & $1(12.5 \%)$ & 0 & $7(85.7 \%)$ \\
\hline $\begin{array}{l}\text { Higher Prepregnancy } \\
\text { alcohol consumption }\end{array}$ & 7 & $100 \%$ & 0 & 0 \\
\hline Being employed & 7 & $2(28.6 \%)$ & 0 & $5(71.4 \%)$ \\
\hline $\begin{array}{l}\text { Higher number of } \\
\text { weeks of gestation }\end{array}$ & 6 & $2(33.3 \%)$ & $1(16.7 \%)$ & $3(50 \%)$ \\
\hline $\begin{array}{l}\text { Higher income/social } \\
\text { class }\end{array}$ & 5 & $4(80 \%)$ & 0 & $1(20 \%)$ \\
\hline $\begin{array}{l}\text { Screening positive for } \\
\text { alcohol problems }\end{array}$ & 5 & $4(80 \%)$ & 0 & $1(20 \%)$ \\
\hline $\begin{array}{l}\text { Exposed to } \\
\text { abuse/violence }\end{array}$ & 3 & $3(100 \%)$ & 0 & 0 \\
\hline $\begin{array}{l}\text { Psychiatric symptoms } \\
\text { (anxiety, depression) }\end{array}$ & 3 & $2(67 \%)$ & 0 & $1 \quad(33 \%)$ \\
\hline
\end{tabular}




\subsection{Study II - Towards improved alcohol prevention in Swedish antenatal care?}

In Study II, alcohol-preventive education and practice as well as perceived knowledge among Swedish midwives was investigated. The share of midwives who had undertaken 3 days or more of continued professional education on alcohol-related matters more than doubled between baseline and follow-up. In 2009 over $97 \%$ of the midwives reported using a questionnaire to detect women with hazardous drinking behaviors before pregnancy compared to about one third in 2006.

The share of midwives who considered themselves to have 'good' or 'very good' knowledge about detection of women with hazardous alcohol habits before pregnancy increased substantially between baseline and follow-up (Table 2). Most midwives in the follow-up study felt that they had become better at initiating conversations on alcohol and at providing information, advice and discussing alcohol with pregnant women during the past three years. Midwives who had initiated the education on alcohol-related issues themselves and had taken part in education on screening were more likely to rate their knowledge as 'very good' (OR 2.7, 95\% CI 1.7-4.3 and OR 2.4, 95\% CI 1.5-3.8). 
Table 4. Alcohol-related education, practice and knowledge at baseline 2006, and at follow-up 2009, among midwives.

\begin{tabular}{|c|c|c|}
\hline Variables & $2006, n(\%)$ & $2009, n(\%)$ \\
\hline $\begin{array}{l}\text { Total amount of continuing professional education on } \\
\text { handling risky drinking }\end{array}$ & 944 & 1098 \\
\hline None & $117(12.4)$ & $12(1.1)$ \\
\hline Half a day or less & $234(24.8)$ & $87(7.9)$ \\
\hline $1-2$ days & $298(31.6)$ & $267(24.3)$ \\
\hline 3 days or more & $295(31.3)$ & $732(66.6)$ \\
\hline Use of questionnaire to detect risky drinking & 974 & 1108 \\
\hline Yes & $338(35.3)$ & $1080(97.5)$ \\
\hline No & $619(64.7)$ & $28(2.5)$ \\
\hline $\begin{array}{l}\text { Perceived knowledge about detection of women with } \\
\text { risky drinking before the pregnancy }\end{array}$ & 959 & 1085 \\
\hline Very good & $37(3.9)$ & $136(12.5)$ \\
\hline Good & $541(56.4)$ & $861(79.4)$ \\
\hline Fair or poor & $381(39.7)$ & $88(8.1)$ \\
\hline Perceived knowledge about alcohol and pregnancy & 954 & 1100 \\
\hline Very good & $239(25.1)$ & $354(32.2)$ \\
\hline Good & $657(68.9)$ & $730(66.4)$ \\
\hline Fair or poor & $58(6.1)$ & $16(1.5)$ \\
\hline
\end{tabular}




\subsection{Study III - Prevalence of alcohol use before and during pregnancy and predictors of drinking during pregnancy}

The aim of Study III was to investigate alcohol use before and during pregnancy as well as predictors of drinking during pregnancy in Sweden.

It was found that $84 \%$ of the pregnant women included in the study drank alcohol in the year preceding pregnancy, while $16 \%$ were abstainers. Hazardous consumption due to binge drinking (see section 5.6 for definition) and/or high weekly consumption in the year before becoming pregnant were reported by $14 \%$ of the women. The hazardous drinkers were more often single, more often lived in a major city, had stronger alcohol habits and were more likely to use tobacco than the moderate drinkers. Almost one quarter (24\%) of the women aged 24 or younger were hazardous drinkers before pregnancy, compared to about $10 \%$ among women aged 35 or older (figures not reported in the article). Further, fewer than one in five women with hazardous drinking decreased their alcohol consumption when planning pregnancy compared to one third of the women with moderate drinking habits $(19 \%$ compared to $33 \%, \mathrm{p}=<0.001)$.

Most women, both moderate and hazardous drinkers, reported decreasing their alcohol consumption when they became aware of their pregnancy. As many as $93.5 \%$ of the non-abstainers (or $94.5 \%$ of the whole sample) reported total abstinence after pregnancy recognition. Among the 89 women $(5.5 \%)$ who reported any consumption, over $90 \%$ consumed a maximum of one standard drink per occasion and a majority (72\%) reported having consumed alcohol 1-2 times thus far during their pregnancy. Among women aged 24 or younger, $3 \%$ consumed alcohol compared to $19 \%$ among women aged 40 or older (figures not reported elsewhere).

Using logistic regression analysis, several factors were assessed for association with drinking during pregnancy. Women aged 35-39 years were 8 times more likely to drink during pregnancy compared to women aged up to 24 years (OR 8.51, 95\% CI 1.8-40.32), and women aged 40 or older were 11 times more likely to drink (OR 11.32, 95\% CI 1.85-96.15). Women who used tobacco on a daily basis were almost four times more likely to consume alcohol than women who did not use tobacco at all (OR 3.76, 95\% CI 1.57-9.00). Women attending 
antenatal care in one of the three largest cities in Sweden had a $69 \%$ increased risk of drinking during pregnancy (OR 1.69, 95\% CI 1.00-2.86). Higher scores on the social support index were associated with lower risk for alcohol consumption during pregnancy (OR 0.87 95\% CI 0.77-0.98) as was lower scores on drinking habits before pregnancy (OR 0.86 95\% CI 0.80-0.93). Drinking for social reasons was associated with an increased likelihood of drinking during pregnancy (OR 1.12 95\% CI 1.00-1.26).

\subsection{Study IV - Asking about alcohol consumption during pregnancy}

In Study IV, self-reported alcohol consumption during pregnancy was compared between two groups. The women in group A, were asked to report their alcohol consumption 'during pregnancy'. The women in group $\mathrm{B}$, were also asked to report their alcohol consumption 'during pregnancy, i.e. after pregnancy recognition'.

In group $A, 14 \%$ of the women were abstainers in the year prior to pregnancy and in group B, 13\% were abstainers. In group A, $7 \%$ of the women reported consuming more than 5 standard drinks on the same occasion at least once a month before pregnancy. The corresponding figure in group B was $3 \%$.

The results showed that the way the questions were worded influenced the results. Among the women in group A, 9.3\% of the whole sample (or $10.6 \%$ of the non-abstainers) reported having consumed alcohol. The corresponding figure for group B was $6.8 \%$ of the whole sample (or $7.4 \%$ of the non-abstainers). When controlling for co-variates, the women in group A were more than $50 \%$ more likely (OR 1.54, 95\% CI 1.07-2.21) than the women in group B to report drinking during pregnancy. Further, in group A, $10 \%$ of the consumers reported drinking 2 or more glasses per occasion, and six women (6.4\%) reported having engaged in binge drinking during pregnancy. In group B, on the other hand, all consumers during pregnancy reported drinking at most one standard drink per occasion while pregnant. 


\subsection{Study V - Non-pregnant women's voices on alcohol consumption during pregnancy}

In Study V, the voices of non-pregnant women concerning alcohol consumption and its relation to pregnancy were explored. Three themes and seven subthemes were identified through the thematic analysis (Figure 1). In the theme 'An issue that cannot be ignored', the study participants stated that alcohol consumption is expected among women of fertile age in Sweden and that if someone decides not to drink, she will be asked about her reasons for this decision. The expectations varied somewhat within and between the groups, as some women expressed that they were expected to drink in moderation and to maintain control, while others were expected to get drunk. The women used different strategies to avoid having their decision questioned, such as avoiding going to parties, choosing non-alcoholic options or providing an excuse, such as being the designated driver or having health problems.

Although all study participants were aware that alcohol use during pregnancy is harmful, the results in the theme 'Awareness and uncertainty regarding alcohol and pregnancy' revealed that their knowledge about specific outcomes was limited. A minority of the participants could name specific consequences of fetal alcohol exposure. The participants expressed a great deal of uncertainty concerning the impact of exposure in different stages of pregnancy. A need for more information on the effects of alcohol consumption during pregnancy was expressed in all of the interviews.

In the theme 'Transition to parenthood', study participants stated that they found total abstinence to be the only responsible option during pregnancy. Further, decreased alcohol intake among both men and women was viewed as important to the process of becoming a parent. However, when discussing alcohol consumption while trying to conceive, different opinions were expressed. While some women thought that early pregnancy was the most vulnerable period for the fetus and planned to maintain total abstinence when trying to conceive, others reasoned that they would probably not abstain until their potential pregnancy was confirmed. 


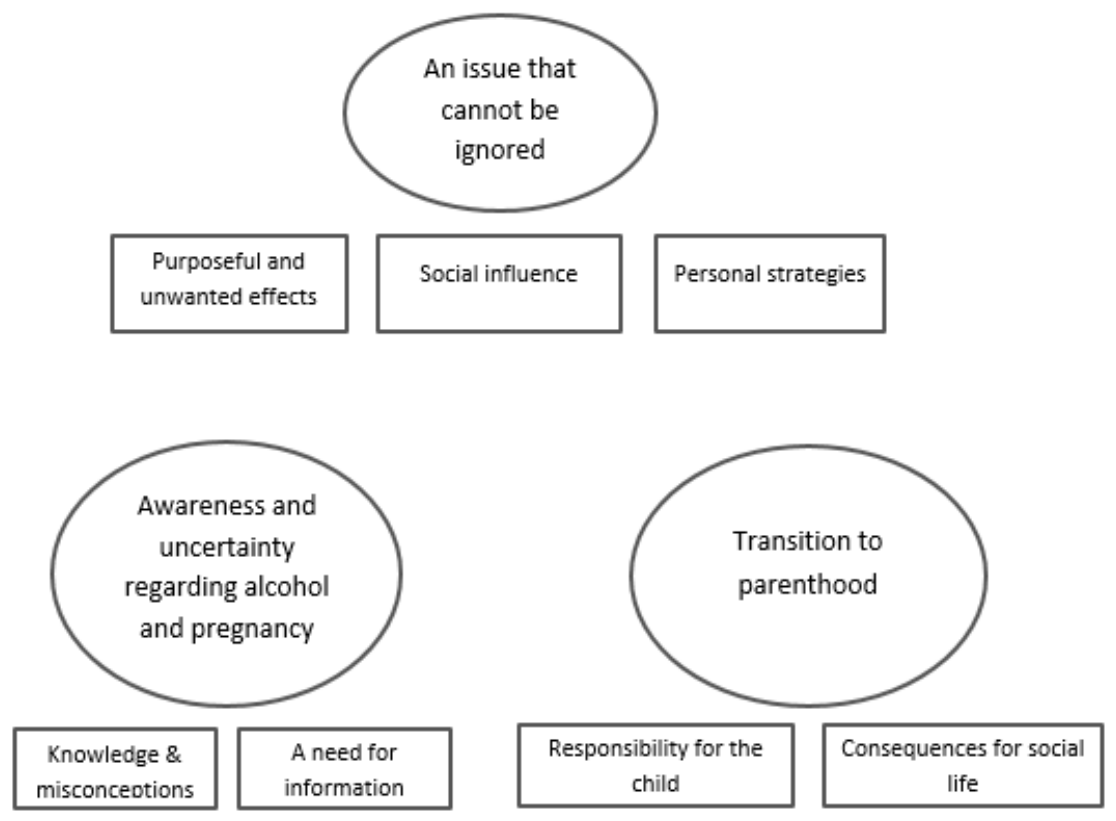

Figure 1: Thematic map of non-pregnant women's voices on alcohol consumption during pregnancy.

\subsection{Summary of the main findings}

Women of fertile age are expected to drink alcohol. Although consuming alcohol after pregnancy recognition is thought to be irresponsible, there are more diverse opinions regarding alcohol consumption during the periconceptional period (Study V). This is also reflected by the fact that the majority of women do not decrease their alcohol consumption before becoming aware of their pregnancy (Study III).

Despite the general agreement that alcohol consumption during pregnancy is harmful (Study V), recommendations to abstain throughout pregnancy and the extensive alcohol-preventive work carried out in antenatal care (Study II), there are still women who consume alcohol after pregnancy recognition (Study III 
and IV). However, seen in an international perspective, both the prevalence of drinking and the amounts consumed seem to be relatively low in Sweden.

Drinking before pregnancy is an important predictor of drinking during pregnancy (Study I and III). Among Swedish women, older age and stronger pre-pregnancy drinking habits are correlated with more drinking (Study III).

Following the massive educational effort and revised work-routines in antenatal care, almost all midwives use a screening questionnaire to detect women who engage in risky drinking (study II). Non-pregnant women of fertile age have limited knowledge of alcohol and pregnancy and there is a call for preventive activities aimed at young people who are not pregnant (study V). 



\section{DISCUSSION}

This chapter discusses the findings of the five studies. The overall aim of the thesis was to generate knowledge on prevalence, predictors and prevention concerning alcohol consumption among women before and during pregnancy. These three themes are used as headings to structure the discussion. This is followed by a discussion of methodological issues pertinent to the studies.

\subsection{Prevalence of alcohol consumption before and during pregnancy}

The prevalence of alcohol consumption before and during pregnancy in Sweden was estimated in Study III. Additionally, in Study IV prevalence was investigated in two groups using different questions. Also, in Study V some discussions touched on the prevalence and pattern of drinking.

The results on alcohol consumption before pregnancy differed somewhat between the national sample with concurrent reporting (Study III) and the single-center sample with retrospective reporting (Study IV). Although the share of abstainers in the year preceding pregnancy was similar in the studies, only 3\% and $7 \%$ reported binge drinking in the two groups in Study IV, compared to $14 \%$ binge drinkers in Study III. The proportion of hazardous consumers in Study III is comparable to national figures from the general Swedish population, which show that $13 \%$ of women of all ages are hazardous drinkers (24\% of women aged $16-29$ years and $9 \%$ of women aged $30-44$ years) (The Swedish Council for Information on Alcohol and Other Drugs, 2014). On the other hand, data from screening with AUDIT for the year preceding pregnancy in routine antenatal care that are entered into the women's patient records show a prevalence of hazardous drinkers of less than 5\% (scores 6-9 points on the AUDIT) and less than $1 \%$ score 10 points or more (indicating misuse) (Pregnancy quality registry, 2013). We did not use the full AUDIT, and the figures are not directly comparable. Even so, these figures imply that women may underestimate their pre-pregnancy drinking when reporting it to antenatal care. 
The women in Study V voiced that there are social expectations to drink alcohol among women of childbearing age. This is in line with research showing that unproblematic drinking, as opposed to both abstinence and excessive drinking, is the norm in many societies (Social Issues Research Centre, 1998). For example, a Danish focus group study examining cultural norms on alcohol consumption found that not drinking was considered odd (Grønkjær et al., 2011). Applying Rogers' Diffusion of Innovations theory (2003), Grittner and colleagues (2013) suggest that drinking patterns can be seen as an innovation that diffuses from men to women in high-income countries, then further to women in low-income countries. After the 1960s, an increase in women's alcohol consumption occurred in several high-income countries, with male and female drinking patterns becoming more similar. When typical male drinking behaviors are adopted by females, they are often seen as a reflection of increased gender equality (Bloomfield et al., 2010).

The difference in reported alcohol consumption before pregnancy in Study III and IV could be due to dissimilar alcohol consumption in the study populations that can be attributed to, for example, differences in sociodemographic characteristics. In Study V, the expectations concerning amount and patterns of alcohol consumption varied within and between the groups. In a thesis investigating alcohol cultures, Bernhardsson (2014) found that youths in Sweden support the idea that teenagers should drink alcohol, be curious and break boundaries so as to eventually become a mature adult person. Further, it was found that young people who favored the drunkenness norm commonly presented themselves as social, fun and creative. In contrast, the minority who advocated moderate drinking usually described themselves as independent and responsible, and they viewed themselves as protestors against the dominant alcohol norm (Bernhardsson 2014).

Another potential explanation for the differences is the time point for data collection. The probability of incorrect recall has been found to increase with longer time interval between assessment and occurrence of the event (Margetts, 2003). The women in Study IV were asked 3-6 months port-partum to report their alcohol consumption during the year before pregnancy, which means that they were in fact asked to recall alcohol consumption dating one to two years back in time.

The majority of women in Study III who consumed alcohol prior to pregnancy recognition continued to drink until they became aware of their pregnancy. 
Among the $14 \%$ who were hazardous drinkers before pregnancy, over $80 \%$ reported changing their alcohol consumption upon pregnancy recognition. Similar results have been found in previous studies. For example, in their study of pregnancy planning among Swedish women, Tydén and colleagues (2011) found that only about $10 \%$ of pregnant women had changed their alcohol consumption when planning pregnancy. A Danish study on pregnancy planning showed that $20 \%$ of women with a high degree of pregnancy planning reported binge drinking in early pregnancy, as did $31 \%$ of women with a low degree of pregnancy planning (Backhausen et al., 2014). Further, using the Timeline Followback Method, Magnusson and colleagues (2005) showed that $15 \%$ of pregnant women sampled in central Stockholm consumed alcohol in a binge pattern or at levels exceeding $70 \mathrm{~g} /$ week at least twice during the first six weeks of pregnancy. In an American study, $54 \%$ of women who wanted to have a child within 12 months and were not sterile, not using contraception and not already pregnant reported drinking alcohol during the past month (Anderson et al., 2006). Another American study reported that $50 \%$ of pregnant women drank pre-pregnancy recognition, whereof $11 \%$ did so in a binge drinking manner (Tough et al., 2006). Corresponding figures from Canada show that $13 \%$ engaged in binge drinking before pregnancy recognition (McDonald et al., 2014). Bearing in mind the risks of drinking in early pregnancy (see section 2.4), a considerable proportion of women chose to drink, even in a binge manner, during this period.

The results from Study V indicate that the social stigma of drinking during pregnancy does not seem to include the time before pregnancy recognition. Similar results have been found in other settings. For example, in an Australian study, some pregnant women found it acceptable to drink in early, but not late pregnancy (Jones \& Telenta, 2012). Likewise, in an American focus group study, a number of women of childbearing age admitted that they would continue drinking until pregnancy recognition (Elek et al.,, 2013). Social norms as well as awareness of potential effects of drinking at different time points are likely to influence women's decisions to drink or abstain. According to Social Cognitive Theory (Bandura, 1986) beliefs about the outcome in form of harm for the child as well as outcomes in form of social reactions if drinking during pregnancy are important for motivation to change a behavior. Another potential explanation for drinking in the periconceptional period is unplanned pregnancies.

Most pregnant women in Study III reported they that had stopped consuming alcohol completely after pregnancy recognition. The prevalence rate of any 
alcohol consumption varied from $0-14 \%$ among the 30 antenatal care centers included in Study III, with 5.5\% in the total sample. Previous Swedish studies using self-reports have reported similar (Comasco et al., 2012; Nilsen et al., 2008; Wurst et al., 2008) or higher prevalence rates (Goransson et al., 2003) from single centers. Prevalence rates reported in international studies vary greatly, from 5\% in Japan (Tamaki et al., 2008), $8 \%$ in the U.S (CDC, 2012), 45\% in Denmark (Nybo-Andersen et al., 2012), to $20-80 \%$ in Ireland (O'Keeffe et al., 2015). There are numerous explanations for this wide range of international prevalence figures. Cultural differences in female drinking in general, including religious beliefs and views on drinking during pregnancy are potentially important explanations. May and Gossage (2011) listed the maternal as well as environmental risk factors for FASD that recur in the literature (note that these may differ from risk factors for any drinking). Maternal risk factors include low education, psychological distress and infrequent practice of religion/spirituality. Environmental risk factors include the culture accepting heavy drinking, little or no knowledge or awareness of FASD and popularity of alcohol-centered recreation (May \& Gossage, 2011). Several of these risk factors are likely to differ between the samples in the studies listed above. Another explanation for the various prevalence results could be difference in the way questions concerning alcohol are posed. As found in Study IV, more women reported alcohol consumption during pregnancy when they were not specifically asked to exclude the period before pregnancy recognition. Further, if a method is used that explicitly includes this period, for example, the Alcohol Timeline Followback Method, even more women will report drinking during pregnancy (see, e.g., Magnusson et al., 2005).

\subsection{Predictors of drinking during pregnancy}

Two of the studies identified various predictors of drinking during pregnancy. Higher pre-pregnancy alcohol consumption was associated with more alcohol consumption during pregnancy in international studies (Study I) and in the study conducted in Sweden (Study III). However, in the Swedish study, the score on the habit index, measuring strength of alcohol habits prior to pregnancy, was found to be a stronger predictor than both frequency and quantity of alcohol consumption. In this connection, Palma and colleagues (2007) found that drinking on weekdays but not weekends predicted alcohol consumption during pregnancy. These findings suggest that it may be more 
difficult to stop frequent drinking at small levels, as compared to more occasional drinking, in association to pregnancy. This is because behaviors that are repeated in stable contexts develop into automatically enacted behaviors. Associations form in memory between the behavior and features of the context (e.g., an environment) in which the behavior is usually performed, such that the behavior becomes cued automatically by the context (Lally et al., 2010; Neal, 2006; Verplanken et al., 1997). Study III and Palma et al. (2007) both found that it was more common for older study participants to consume alcohol, implying that they are more likely than younger women to have developed drinking habits that may be difficult to break during pregnancy.

On the other hand, the small amounts and limited frequency of alcohol consumption reported by most women who drank during pregnancy indicate that the drinking is not completely habitual, but rather consciously controlled (i.e. 'non-automatic'). As a behavior becomes increasingly habitual, research has shown that the importance of self-efficacy, attitudes and motivation concerning the behavior decreases (Verplanken \& Faes, 1999). Breaking habits may require a contextual change, as this offers a possibility to limit habitual responding through discontinuation of exposure to habit cues. This change makes it possible to reconsider a behavior and bring behavioral decision-making under conscious control (Verplanken \& Velsvik, 2008). It has been suggested that pregnancy itself may represent a contextual change that provides a 'window of opportunity' for breaking habits, such as drinking alcohol (Holmes \& Rahe 1967; Nilsen, 2009). Further, as proposed by Wood and Neal (2007), habits and goals interact so that people can act habitually on some occasions, but then intentionally inhibit responses to cues in order to behave in a more desirable manner on other occasions. Perhaps, during pregnancy, when exposed to contextual cues that activate a response to drink alcohol, women inhibit the response by intentionally choosing an alcohol-free option or to drink half a glass based on their knowledge about the lack of evidence of harm when consuming small amounts of alcohol.

Another predictor of alcohol consumption during pregnancy found in Study III was higher scores on social drinking motives as opposed to coping or enhancement motives. Social drinking motives have been associated with more infrequent and less heavy drinking as well as less abusive drinking than have the other motives (Cooper ML, 1992). This is in line with earlier findings showing that most pregnant women who consume alcohol in Sweden are not alcohol dependent (Magnusson et al., 2007). In contrast, in the review (Study I) 
screening positive for alcohol problems was associated with more drinking during pregnancy in 4 out of 5 studies assessing the relationship. One possible explanation for these differences is the different study settings. In Study III as well as the study by Magnusson et al. (2007), women were recruited via antenatal care. In some regions in Sweden, women with confirmed alcohol problems are referred to specialist antenatal care; these clinics were not part of the samples. In the international studies, women with alcohol problems may have been included in the samples to a higher degree.

Drinking at hazardous levels during the year preceding pregnancy was most common among the youngest age group (Study III), in contrast to drinking after pregnancy recognition, which was most prevalent among older women. Almost one in four of the women aged 24 or younger was categorized as a hazardous drinker in the year preceding pregnancy, compared to about $10 \%$ among the women aged 35 or older. These findings suggest that although reported drinking after pregnancy recognition was more common among the older pregnant women in Study III, levels of fetal alcohol exposure may be similar in both groups, or perhaps even higher among the younger women.

Based on the Theory of Planned Behavior (Ajzen, 1988), one could assume that many women have different behavioral intentions concerning alcohol consumption before and after pregnancy recognition. According to the results of Study V both attitudes and subjective norms are probably different for the periconceptional period and confirmed pregnancy. Before pregnancy recognition and pregnancy disclosure, the women are still exposed to a social expectation to drink - an expectation that is reversed at pregnancy disclosure. Further, attitudes toward drinking in the periconceptional period varied more than attitudes toward drinking after pregnancy confirmation (Study V). Another study showed that women sometimes drink in early pregnancy to avoid pregnancy disclosure (Jones \& Telenta, 2012). To avoid drinking in a situation when you are expected to abstain, i.e. during pregnancy, can be perceived as easier than abstaining when you are expected to drink, i.e. before revealing pregnancy. In other words, the perceived behavioral control may change after pregnancy disclosure.

Social Cognitive Theory (SCT) (Bandura, 1986) can also be used to explain drinking during the periconceptional period. The women in Study V provided examples of people in their surroundings who had been drinking during pregnancy and who had given birth to healthy children. SCT proposes that 
other people's behavior and the 'outcome' of these behaviors may play a role in decisions concerning the behavior. These types of stories in combination with lack of information and poor knowledge about the effects of fetal alcohol exposure in early pregnancy may result in expectancies that alcohol exposure during pregnancy is harmless.

Visiting antenatal care in a major city was another factor that was associated with higher prevalence of drinking among the women in Study III. Women in Sweden can chose which antenatal care center to visit during their pregnancy. Some women chose an antenatal care center close to where they work rather than close to their home, meaning that the location of the antenatal care center may not reflect the women's place of residence. The finding that a higher share of women in the three largest cities in Sweden consume more alcohol than women from all other locations is in line with national statistics showing that alcohol use in the general population is high in the three metropolitan counties (Ramstedt, 2013). These differences can be attributed to slightly different alcohol cultures in larger cities compared to small towns and rural areas. It has been pointed out that there are different alcohol cultures among sub-groups within a country, i.e. it may be more accurate to understand alcohol culture in terms of many different sub-cultures (Bernhardsson, 2014). Such findings are consistent with differences in alcohol consumption seen among women with different socio-economic status both during pregnancy (Study I) and in the general population (Devaux, 2015).

\subsection{Prevention of alcohol consumption during pregnancy}

Study II investigated various aspects of the alcohol-preventive work in antenatal care in Sweden. This work underwent numerous changes between 2006 and 2009. According to Study II of this thesis, $98 \%$ of the midwives used an instrument, most often AUDIT, to assess alcohol consumption in 2009 compared to only 35\% in 2006. Further, a higher share of midwives in 2009 initiated a motivational interview when they identified pregnant women with hazardous alcohol consumption.

The results concerning the content of and changes in alcohol-preventive work in antenatal care clearly suggest that new ways of working were very quickly 
implemented and incorporated into routine practice. This observation contradicts the general conclusion drawn in implementation research, which is that implementation is usually a slow, laborious process (Nilsen, 2015).

This may be explained with reference to Rogers' Theory of Diffusion (Rogers, 2003). The theory's notion of innovation attributes, i.e. relative advantage, compatibility, complexity, trialability and observability, has been widely applied to assess the extent to which the characteristics of an "implementation object" affect implementation outcomes (Nilsen, 2015). The new alcoholpreventive routines, including an early consultation on health status, screening with AUDIT, and use of MI, can be considered an innovation and thus be discussed in terms of Rogers' innovation characteristics to understand why implementation appeared to be so successful. Prior to the intervention, the midwives had expressed a need for improved and clearer guidelines on alcoholpreventive work (Holmqvist \& Nilsen, 2010), suggesting that the new directives were perceived as having a relative advantage over previous work routines and as being compatible with the needs of the organization. Further, the complexity of the innovation is low, as the AUDIT is a relatively short instrument and clear guidelines on how to use it and interpret the results are available. The attribute observability refers to the observed effects of using an innovation. For the midwives, the long-term effects that preventive routines can generate may not have been evident, yet many midwives stated that they had become better at initiating conversations on alcohol between baseline and follow-up. Some parts of the work routine, such as the use of MI, could be tested and modified (more than, e.g., use of AUDIT), suggesting a degree of trialability.

Results from Study III and V point to the importance of prevention of prenatal alcohol exposure in more arenas or settings than in antenatal care, underscoring the relevance of primary prevention approaches to drinking during pregnancy. The women of fertile age in Study V were aware that alcohol consumption during pregnancy is harmful. However, they had limited knowledge about the actual processes and potential consequences of drinking during different periods of fetal development. They wanted more information. The kind of efforts and initiatives the women requested included mass media campaigns, education in the schools and pamphlets available in health care centers (i.e, not merely antenatal care). These approaches can be classified as promotion, primary prevention or, using Gordon's (1983) classification, universal prevention (if directed at the entire population) or selective prevention (if focusing, e.g., on women of child bearing age). 
A recent review (Crawford-Williams et al., 2015) examined the effects of public health interventions aimed at reducing alcohol consumption during pregnancy or increasing knowledge about the issue. The review included seven studies involving pregnant women and women of childbearing age. The studies used educational interventions such as television campaigns/commercials, text messages, posters and pamphlets. Most of the included studies found some improvements in knowledge attributed to the public health interventions. Further, two of four studies involving women of fertile age reported decreased alcohol consumption after the interventions (Hanson et al., 2012; Kaskutas \& Graves, 1994). The authors of the review concluded that, due to the limited number of studies on public health interventions to reduce alcohol consumption during pregnancy, the evidence of their effectiveness is limited and more research is needed (Crawford-Williams et al., 2015).

Secondary preventive strategies that have been used to reduce the severity and duration of prenatal alcohol consumption are clinical interventions. For example, the use of Brief Intervention (BI) has been suggested to have a positive effect on alcohol reduction among pregnant women (Bailey \& Sokol, 2008; Gilinsky et al., 2011; Nilsen, 2009). In a review by Gilinsky et al. (2011) that assessed effects of several interventions, including BI, directed at women attending antenatal care longer BI sessions were found to be more effective than shorter. Further, setting a goal of total abstinence during pregnancy and having a partner participating in the intervention seemed to improve the outcome.

An indicated, preventive intervention involving women of childbearing age conducted in the US consisted of written material and two 15-minute counseling sessions. The intervention was offered by physicians to women who scored positive when screened for hazardous alcohol consumption (Manwell et al., 2000). This study found a significant reduction in weekly alcohol consumption as well as binge drinking among women who were assigned to the intervention group compared to controls. At a 2-year follow-up, women in the intervention group had decreased their mean alcohol consumption by $48 \%$. Moreover, regarding women who became pregnant during the study period, women in the intervention group decreased their alcohol consumption significantly compared to the control group (Manwell et al., 2000). Another motivational intervention aimed at enhancing effective contraceptive use in women fertile age who were hazardous drinkers. At six and nine months follow-up women receiving the motivational intervention were twice as likely compared to the 
controls to be at reduced risk of alcohol exposed pregnancy, by either reducing drinking or using effective contraception, or both (Floyd et al., 2007)

Changes in alcohol consumption in relation to parenthood have been seen in life-course research, where changing norms constitute a potential explanation (Neve, 2000; Staff et al., 2010). Most women in Study V felt it was irresponsible to drink when discussing alcohol consumption in relation to pregnancy and parenthood. Both men and women saw cutting down on drinking as an important part of becoming a parent. In a longitudinal study of the meaning of alcohol, 34 men and women belonging to three different socioeconomic categories were interviewed when they were around 20 and then again at about 35 years of age (Törnqvist, 2007). In all three groups, the meaning of alcohol and intoxication had become less important at the follow-up interview, at which time family, children and work had assumed a more important role. Consuming alcohol with children present was viewed differently across the groups. Working-class parents usually refrained from or moderated their drinking in the company of their children because they wanted to be responsible parents. Parents in the more academic group, however, drank alcohol with children present during weekend dinners to relax after the week and to strengthen their relationship with their partner (Törnqvist, 2007). Although female drinking has increased, the ideal mother is still portrayed as responsible and in control, whereas a drunk mother is a taboo that goes against the social norm (Bernhardsson, 2014).

In summary, to prevent prenatal alcohol exposure and associated effects, interventions on different levels could be combined. As found in Study I and III, alcohol consumption before pregnancy is associated with alcohol consumption during pregnancy. Thus, it is important to recognize alcohol consumption among women of childbearing age. Further, the findings indicate that women with increased risk of alcohol consumption during early pregnancy may differ from women with increased risk for alcohol use throughout pregnancy. These two groups may need different kinds of interventions delivered at different places. Moreover, women who are not able to reduce drinking during pregnancy and their children need support after the birth (Streissguth, 2011). 


\subsection{Methodological considerations}

All of the studies in this thesis have methodological strengths and weaknesses that should be taken into account when interpreting the findings and drawing conclusions. In this section, general methodological considerations on study design, samples, data collection and analyses are discussed.

\subsubsection{Study design and approach considerations}

In Study II, a pre-post design with concurrent data collection was used. Recurrent cross-sectional measures can be useful for assessing changes over time (Satten, 2005). However, in this study, it was not possible to assess whether the samples were dependent or independent, as we were not able to identify the respondents. This also meant that it was impossible to statistically assess changes over time. Another limitation was the inability to trace respondents and non-respondents to perform drop-out analyses.

Study III and IV applied cross-sectional study designs. Such a design allows for a snapshot of, for example, the occurrence of alcohol consumption at a specific point in time. A general limitation of cross-sectional design is that it does not account for any time aspects, which makes it difficult to establish any causal inference (Satten, 2005).

In Study IV, two ways of asking about alcohol consumption during pregnancy were compared. The non-specific question merely asked the respondents to assess their alcohol consumption during pregnancy. This means that we cannot tell whether or not the women who answered this question included the time before pregnancy recognition when they gave their response. It would have been advantageous to include a third group in the study to gain an even deeper understanding of how the wording of the question can affect the answers given. This proposed third group would then have been asked explicitly to report about alcohol consumption during pregnancy including the time before pregnancy recognition. Further, to limit the potential impact of design of the questionnaire it would be preferable to use questionnaires that were identical except from the question on alcohol consumption during pregnancy. 
Focus groups interviews were used to collect the data for Study V. The research question was largely unexplored and previous knowledge was lacking, which is why a qualitative method was thought to be appropriate. Focus group interviews were considered to be a beneficial data collection method, as the interaction and influence among the participants provide a more natural environment than individual interviews would have (Krueger \& Casey, 2009). Further, focus group interviews are useful to better understand how people feel or think about a predefined topic (Krueger \& Casey, 2009). The method has been found to be especially useful in assessing how normative understandings are created within groups (Bloor, 2001).

\subsubsection{Validity and reliability}

The quality of quantitative studies is often discussed in terms of validity and reliability. Validity refers to the extent to which something measures what it is intended to measure, while reliability concerns the consistency in results with repeated measures. The validity of the measurement is crucial in studies where constructs rather than actual measures are used (Gallestey 2008).

The systematic review, Study I, did not follow any specific guideline for conducting reviews. Guidelines or frameworks can help authors ensure that the systematic review is transparent and complete in its reporting. Even though the study did not adhere to a specific guideline, all the steps taken in the study were clearly described in the article. Several different guidelines were used as inspiration when creating the approach used for quality assessment and data extraction.

The questionnaires used in the thesis were not subjected to validation or reliability testing. However, the questionnaires featured many instruments and questions that had been subjected to validity and reliability tests in previous studies. All of the questionnaires were constructed by researchers and practitioners following extensive reviews of studies in the research field. The questionnaires were then reviewed in a larger group of researchers, and for Study III, tested using cognitive interviewing.

Study III and IV relied on self-reports of alcohol consumption. In general, the validity of such self-reports has been questioned (Czeizel et al., 2004; Del Boca \& Darkes, 2003). Questions concerning alcohol consumption in pregnancy may 
be especially vulnerable to social desirability, i.e. implying that the respondents answer in a way that they think is socially acceptable rather than telling the truth (Brace, 2004). In a Swedish study comparing self-reported alcohol consumption to results from screening with biological markers, Wurst and colleagues (2008) reported that $9 \%$ of the women $(n=103)$ were identified as drinking during pregnancy when self-reports were used, and $25 \%$ when maternal biological markers were used in combination with self-reports on the AUDIT questionnaire. However, further validation of individual biological markers is needed (Joya et al., 2012). In another Swedish study, Magnusson and colleagues (2005) found that the Timeline Followback Method was better than maternal biomarkers at identifying women drinking in early pregnancy.

More recently, biomarkers found in the meconium have been established for detection of prenatal alcohol exposure. A review of 9 studies found showed that meconium testing to identify prenatal alcohol exposure yielded on average four times higher prevalence rates than self-reported data, even though meconium testing could not detect low levels of alcohol consumption or alcohol consumption in early pregnancy. However, the differences between selfreported alcohol consumption and alcohol exposure detected by biomarkers varied to a great extent in the studies included in the review (Lange et al., 2014).

Another aspect of validity is if the results can be generalized from the study sample to the study population and from the study sample to people outside the population. In Study III, we sought to include women from different areas in Sweden to reflect the distribution found in the population. However, the distribution of participants did not fully reflect the study population due to difficulties in recruiting antenatal care centers that were willing to take part in the study in some areas. One strength of this study was the high response rate among the women asked to participate. In Study IV, the samples consisted of all women who visited antenatal care during two separate time periods (i.e., two separate data collection time points). Randomization into two groups and one data collection could have increased the internal validity.

External validity depends on the extent to which the findings can be generalized to other settings or populations. Study I, the systematic review, included studies conducted across the world. In order to achieve some homogeneity among the included studies, one inclusion criterion was that the studies should collect data during or immediately after pregnancy. In order to enhance the external validity the setting of the studies that identified different predictors for drinking were 
described. Similarities and differences between studies assessing the same predictors were also discussed in the article.

In Study II, the response rate for the baseline and follow-up were $46 \%$ and $62 \%$, respectively. The questionnaire was sent to all active midwives in antenatal care in Sweden, but there was no way to assess the extent to which the answers provided by the included midwives were representative of the whole population. The results can therefore not be generalized beyond the respondents in the study population.

The questionnaires and interviews in Study III, IV and V were written and conducted in Swedish, meaning that women who did not understand Swedish were excluded from the studies. In 2014, about $22 \%$ of Swedish women aged 1544 years were born abroad (Statistics Sweden, 2014). Although many of foreignborn individuals understand Swedish and were part of the sample in Study III, IV and V, others were excluded due to language difficulties. Alcohol consumption before and during pregnancy as well as perceptions and thoughts may differ between Swedish-speaking women and women from other cultures. The exclusion of non-Swedish-speaking women may have led to over- or underestimation of the proportion of women in Sweden who use alcohol.

\subsubsection{Trustworthiness}

The concept of trustworthiness is commonly used in qualitative research when assessing the quality of the research. Trustworthiness includes the four criteria credibility (the concept is roughly similar to internal validity), transferability (analogous to external validity), dependability (analogous to reliability) and confirmability (analogous to objectivity) (Lincoln \& Guba 1985).

Credibility concerns the truth in the research findings. In Study V, credibility thus refers to the agreement between the respondent's truth about alcohol consumption and the interpretation and presentation of this provided by the researchers. The credibility was enhanced by triangulation, as the researchers involved in Study V all carried out initial analyses separately. Also, the results were sent to some of the participants to get their comments on them. 
Transferability concerns the applicability of the results in other contexts. To enhance transferability, we provided a description of the context in which the study was performed. Participants in Study V were recruited from different sites, the aim being to include women from different backgrounds and social conditions. Due to the sampling strategies used, the participants may have differed from the total population. The results were compared to the results of similar studies conducted in other contexts, which may help readers judge the transferability to other settings.

Dependability is concerned with the possibility to repeat the study. To enhance dependability all steps carried out in data collection and analysis were described, and the method of analysis was followed strictly.

Confirmability refers to the degree of neutrality of the researcher and the degree to which the results are supported by the data. In Study V, the themes found in the analysis were reviewed in relation to the entire data set. Further, a researcher not involved in the study examined the process and results of the study. 



\section{CONCLUSIONS}

The five studies included in the thesis provided the basis for several conclusions regarding the three themes of prevalence, predictors and prevention.

- In the year preceding pregnancy, a majority of women in Sweden consume alcohol, a substantial proportion of them drinking at hazardous levels. Most of consumers before pregnancy continue to drink in the same manner until their pregnancy is recognized.

- After pregnancy recognition, the vast majority of women in Sweden refrain from alcohol. Among the women who continue to drink during pregnancy, most report drinking infrequently and not more than one standard drink per occasion.

- When measuring and reporting alcohol consumption during pregnancy it is important to be specific regarding if drinking before pregnancy recognition is included or not.

- Pre-pregnancy drinking, exposure to abuse or violence, screening positive for alcohol problems and higher income/social class are predictors of any drinking during pregnancy reported in several international studies.

- Higher maternal age, living in a major city, using tobacco, low social support, strong alcohol habits and more social drinking motives are associated with alcohol consumption during pregnancy in Sweden.

- Following an educational effort, almost all midwives in antenatal care in Sweden screen pregnant women for hazardous consumption before pregnancy. After the education, the majority of midwives report to be knowledgeable about alcohol and pregnancy and how to detect women with hazardous consumption.

- Non-pregnant women of fertile age in Sweden believe that alcohol consumption during pregnancy is harmful and should be avoided. Their 
knowledge about specific consequences is sparse and interventions to increase the knowledge are called for. 


\section{IMPLICATIONS FOR PRACTICE AND RESEARCH}

The results from the five studies raise questions of relevance to both practice and research. With regard to practical implications, it is clear that prevention of alcohol consumption during pregnancy is a complex, multi-facetted issue that likely requires many different approaches (interventions, campaigns, activities, etc.), both within and outside health care settings. This thesis cannot offer any easy solutions or quick fixes that can be immediately disseminated or implemented. However, there are some practical implications that should be highlighted.

The studies suggest that drinking during pregnancy can be explained at different levels, from the individual to the societal level, and that this problem, at least partially, can be understood with reference to insufficient knowledge among women. Therefore, social marketing campaigns aimed at the whole population and information specifically targeting young people may offer a suitable means of achieving increased awareness, which is an important step toward desirable behaviors - in this case, abstaining from alcohol during pregnancy. No matter how early the first meeting in antenatal care is scheduled the prevention will be directed to women who are aware of their pregnancies, and of whom most have already decreased their alcohol consumption. Provision of relevant information on the risks of drinking in early pregnancy and before pregnancy recognition needs to be addressed also in health care settings such as youth health clinics, contraceptive clinics and STI (sexually transmittable infections) clinics. In order for prospective parents to be able to make informed choices regarding drinking in the periconceptional period they need to have accurate information.

The findings of Study II suggest the importance of antenatal care practitioners being knowledgeable and feeling secure in their role, which involves intervening to prevent drinking during pregnancy. Practitioners working in other areas of health care, such as health clinics and STI clinics, will also likely benefit from education and training in alcohol prevention issues. Recurrent continuous professional education makes it possible to maintain and enhance the alcohol-preventive skills of practitioners in various settings. 
A related issue is whether women underreport their drinking during pregnancy. There is an obvious risk for this as a result of social expectations to abstain during this period of life. The social stigma associated with any alcohol consumption during pregnancy might be decreased if antenatal care practitioners were to provide clear information on the lack of evidence for risks associated with low levels of alcohol consumption during pregnancy and explain the precautionary principle behind the total abstinence policy. Research exploring how women reason when reporting alcohol consumption during pregnancy in antenatal care would seem to be highly relevant.

Concerning research, there is a need for more exploration and investigation into many of the aspects touched upon in the five studies included in this thesis. For instance, more knowledge is needed regarding the effectiveness of various interventions, such as information campaigns and education. To what extent can interventions impact on women's knowledge, drinking and risk of alcohol exposed pregnancy, as well as intention to drink and actual drinking during the periconceptional period? What are the causal mechanisms underlying different types of interventions? How important are the individual's attitudes, beliefs, knowledge, motivation and intention concerning the behavior (i.e., drinking during pregnancy) and the risks associated with the behavior? What is the role of the partner, friends, and other women? And how important is the drinking culture at different levels, from friends and smaller groups to society as a whole?

Antenatal care practitioners' current practice of screening would seem to be well suited to identifying women with increased risk of drinking throughout pregnancy. However, the feasibility and effectiveness of different screening tools or instruments should be assessed in future research. Considering the importance of pre-pregnancy drinking habits for continued drinking during pregnancy, one important issue is whether the extent to which these habits are captured in the tools currently being used in antenatal care. 


\section{SVENSK SAMMANFATTNING}

Det har länge varit känt att exponering för alkohol under fostertiden kan leda till en rad konsekvenser för det drabbade barnet, vissa av dem livslånga. Konsekvenser av exponering för stora mängder alkohol är klarlagda men det är ännu oklart hur små mängder påverkar. Utifrån försiktighetsprincipen rekommenderas kvinnor i många länder, däribland Sverige, att avstå helt från alkohol när de är gravida. Trots dessa rekommendationer har studier visat att en betydande andel kvinnor dricker alkohol under tiden runt befruktning och under graviditeten. Det övergripande syftet med denna avhandling var att generera kunskap om förekomst av alkoholkonsumtion under graviditet, faktorer som har samband med ökad risk att dricka alkohol under graviditet samt förebyggande arbete. Dessa aspekter undersöktes i fem studier.

Flera olika metoder och datakällor användes för att besvara syftet. För att identifiera vilka faktorer som har samband med alkoholkonsumtion under graviditet i internationell forskning gjordes en systematisk översiktsartikel (Studie I). För att samla in uppgifter om alkoholförebyggande arbete från barnmorskor i mödrahälsovården användes enkäter (Studie II). Ytterligare enkäter användes för att samla in uppgifter om alkoholkonsumtion före och under graviditeten från gravida kvinnor och nyblivna mammor (Studie III och IV). Fokusgruppsintervjuer genomfördes för att undersöka icke-gravida kvinnors röster om alkoholkonsumtion och graviditet (Studie V).

Sammantaget visar resultaten från de fem studierna att alkoholkonsumtion var vanligt förekommande bland kvinnor i fertil ålder i Sverige (Studie III-V) och att det fanns en social förväntan på kvinnor att dricka (Studie V). Under graviditeten förändrades dessa förväntningar och kvinnor förväntas då avstå från all alkoholkonsumtion (Studie V). Detta överensstämmer med de råd som ges i mödrahälsovården. Det nationella Riskbruksprojektet ledde till reviderade alkoholförebyggande rutiner i svensk mödravård och vid uppföljning av projektet uppgav så gott som samtliga barnmorskor att de screenade alla gravida kvinnor för riskbruk av alkohol (Studie II). En stor majoritet av gravida kvinnor och nyblivna mödrar rapporterade att de avstod från alkohol efter att de blivit medvetna om sin graviditet (Studie III och IV). Kvinnor som ombads svara på hur mycket de hade druckit under sin graviditet, efter medvetenhet 
om graviditeten rapporterade lägre alkoholkonsumtion än kvinnor som ombads att rapportera hur de druckit under sin graviditet, utan instruktion om att exkludera tiden innan medvetenhet om graviditet (Studie IV). Faktorer som var förknippade med mer drickande under graviditeten i ett svenskt urval var; att bo i en storstad, högre ålder, tobaksbruk, lågt socialt stöd, starkare alkoholvanor innan graviditet och starkare sociala dryckesmotiv (Studie III). Faktorer som konsekvent visats ha ett samband med alkoholkonsumtion under graviditet $\mathrm{i}$ internationell forskning var: alkoholkonsumtion innan graviditet; att vara utsatt för misshandel eller våld; hög inkomst eller social klass; och att screena positivt för alkoholberoende (Studie I). Kvinnor i fertil ålder i Studie V var osäkra på vilka effekter alkoholkonsumtion i perioden kring befruktning kan ge. Vidare verkade de sociala förväntningarna på att avstå från alkohol inte vara lika starka under tiden kring befruktning som efter en bekräftad graviditet. I Studie III uppgav en majoritet av kvinnorna att de minskat sin alkoholkonsumtion först när de blev medvetna om att de var gravida. 


\section{ACKNOWLEDGEMENTS}

As a PhD student I have sometimes received the question if it's not lonely to work all by myself. Well... although it is my PhD project I have never felt that I do this research by myself, Actually, I'm not sure I would have made it on my own. Throughout my PhD time I've worked with, and received support from, many people whom I wish to thank.

Per Nilsen, my main supervisor, I am so grateful for all your encouragement and support from the very first beginning of my PhD time until the final writing up of the thesis. Not just in your course, but through-out these years I have learnt a lot about the art and science of scientific writing through your generous comments. Although a cliché, I've always felt that you believe in me.

To my co-supervisors, Siw Alehagen and Elisabet Häggström-Nordin - thank you for all guidance! Siw, your positive attitude and commitment to our studies have been a great inspiration. Elisabet, you have posed valuable questions that have often made me clarify things even to myself.

I am really grateful to all midwives, pregnant women, new mothers and women of childbearing age who have participated in the studies. Further, staff at antenatal care centers who have helped with data -collection, thank you!

I've had the opportunity to co-write my articles with several skilled colleagues; Grace Chang, AnneLie Johansson, Marika Holmqvist, Eva-Karin Envall, Kristofer Årestedt, Karin Festin and Marie Blomberg, thank you for good cooperation. It has been a pleasure collaborating with you and some of your contributions have been very valuable for my studies.

To past and present members of the LIIR -group, thanks for all discussions, critical comments on drafts and for the open atmosphere.

Thanks to all past and present friends and colleagues at the division of Community Medicine for discussions, encouragement and laughter. Special thanks to Kajsa Bendtsen for your positivity and for making administrative practice and endless forms understandable. 
Past and present $\mathrm{PhD}$ buddies at $\mathrm{IMH}$, thanks for sharing this experience with me and for practical and emotional support. Special thanks to Mikaela Ridelberg for supporting me to become a doctoral student from the beginning.

In some unbelievable way I have always been placed with the best possible $\mathrm{PhD}$ roommates who have also become my friends. Kristin "Puff" Thomas, thanks for listening and understanding and for all everyday conversations on everything. Petra Dannapfel, thanks for sharing all your positive energy and many memorable times with me. Karolina Kristenson, thank you for being the perfect role model when it comes to writing a thesis and handling a public defense.

Last but certainly not least, my family. Mum and dad - thank you for helping out when needed. ERIC, LOVA and EBBE - thank you for always being there for me and for bringing those wonderful contrasts into my world. Ni betyder allt för mig! 


\section{REFERENCES}

Abel, E. L. \& Sokol, R. J. 1987. Incidence of fetal alcohol syndrome and economic impact of FAS-related anomalies. Drug Alcohol Depend, 19, 5170.

Ajzen, I. 1988. Attitudes, Personality and Behavior, Milton Keynes, Open University Press.

Allebeck, P. \& Olsen, J. 1998. Alcohol and fetal damage. Alcohol Clin Exp Res, 22, 329S-332S.

Alvik, A., Haldorsen, T., Groholt, B. \& Lindemann, R. 2006a. Alcohol consumption before and during pregnancy comparing concurrent and retrospective reports. Alcohol Clin Exp Res, 30, 510-5.

Alvik, A., Heyerdahl, S., Haldorsen, T. \& Lindemann, R. 2006b. Alcohol use before and during pregnancy: a population-based study. Acta Obstet Gynecol Scand, 85, 1292-8.

Alberta Medical Association. 2003. Prevention of fetal alcohol syndrome (FAS). The Canadian child and adolescent psychiatry review $=$ La revue canadienne de psychiatrie de l'enfant et de l'adolescent, 12, 87-91.

American Academy of Pediatrics. 2000. Fetal Alcohol Syndrome and AlcoholRelated Neurodevelopmental Disorders. Pediatrics, 106, 358-361.

Backhausen, M. G., Ekstrand, M., Tyden, T., Magnussen, B. K., Shawe, J., Stern, J. \& Hegaard, H. K. 2014. Pregnancy planning and lifestyle prior to conception and during early pregnancy among Danish women. Eur J Contracept Reprod Health Care, 19, 57-65.

Bailey, B. A. \& Sokol, R. J. 2008. Pregnancy and alcohol use: evidence and recommendations for prenatal care. Clin Obstet Gynecol, 51, 436-44.

Bailey, B. A. \& Sokol, R. J. 2011. Prenatal alcohol exposure and miscarriage, stillbirth, preterm delivery, and sudden infant death syndrome. Alcohol Res Health, 34, 86-91.

Balachova, T., Bonner, B., Chaffin, M., Bard, D., Isurina, G., Tsvetkova, L. \& Volkova, E. 2012. Women's alcohol consumption and risk for alcoholexposed pregnancies in Russia. Addiction, 107, 109-17.

Bandura, A. 1986. Social Foundations of Thought and Action: A Cognitive Social Theory, Englewood-Cliffs, NJ, Prentice-Hall.

Bandura, A. 1998. Health promotion from the perspective of social cognitive theory. Psychology \& Health, 13, 623-649. 
Bargh, J. A. \& Chartrand, T. L. 1999. The unbearable automaticity of being. American Psychologist, 54, 462-479.

Barrow, M. \& Riley, E. P. 2011. Diagnosis of fetal alcohol syndrome: emphasis on early detection In: Preece, P. M. \& Riley, E. P. (eds.) Alcohol, drugs and medication in pregnancy - the long-term effect for the child. London: Mac Keith Press.

Berglund, A. Lundberg, G. Sandén, E. Lindroth, M. Lindholm, E. Nilses, C. 2008. Mödrahälsovårdens organistaion, struktur och kvalitetsuppföljning. In: Mattson, L.-Å. (ed.) Mödrahälsovård, Sexuell och Reproduktiv hälsa. intressegruppen för mödrahälsovård inom SFOG.

Bernhardsson, J. 2014. Normalitetens gränser - En fokusgrppsstudie om alkoholkultur(er), genus- och åldersskapande. Stockholm University.

Bloomfield, K., Wicki, M., Gustafsson, N. K., Mäkelä, P. \& Room, R. 2010. Changes in alcohol-related problems after alcohol policy changes in Denmark, Finland, and Sweden. J Stud Alcohol Drugs, 71, 32-40.

Bloor, M. 2001. Focus groups in social research, London, Sage.

Brace, I. 2004. Questionnaire design: how to plan, structure, and write survey material for effective market research [Online]. London ; Sterling, VA: Kogan Page,. Available: http://www.loc.gov/catdir/toc/ecip0417/2004010045.html

Braun, V. \& Clarke, V. 2006. Using thematic analysis in psychology. Qualitative Research in Psychology, 3, 77-101.

Bush, K., Kivlahan, D. R., McDonell, M. B., Fihn, S. D. \& Bradley, K. A. 1998. The AUDIT alcohol consumption questions (AUDIT-C): an effective brief screening test for problem drinking. Ambulatory Care Quality Improvement Project (ACQUIP). Alcohol Use Disorders Identification Test. Arch Intern Med, 158, 1789-95.

Centrum for disease control and prevention, CDC. 1995. Update: trends in fetal alcohol syndrome - United States, 1979-1993. MMWR Morb Mortal Wkly Rep, 44, 249-251.

Centrum for disease control and prevention, CDC. 1997. Surveillance for fetal alcohol syndrome using multiple sources - Atlanta- Gerogia, 1981-1989. MMWR Morb Mortal Wkly Rep.

Centrum for disease control and prevention, CDC. 2012. Alcohol use and binge drinking among women of childbearing age - United States, 20062010. MMWR Morbidity and Mortality Weekly Report.

Clarke, M. E. \& Gibbard, W. B. 2003. Overview of fetal alcohol spectrum disorders for mental health professionals. Can Child Adolesc Psychiatr Rev, 12, 57-63. 
Clarren, S. K., Randels, S. P., Sanderson, M. \& Fineman, R. M. 2001. Screening for fetal alcohol syndrome in primary schools: a feasibility study. Teratology, 63, 3-10.

Coles, C. 1994. Critical periods for prenatal alcohol exposure. Alcohol Health $\mathcal{E}$ Research World, 18.

Comasco, E., Hallberg, G., Helander, A., Oreland, L. \& Sundelin-Wahlsten, V. 2012. Alcohol Consumption Among Pregnant Women in a Swedish Sample and Its Effects on the Newborn Outcomes. Alcohol Clin Exp Res, 36, 1779-1786.

Conner, M., Norman, P. 2005. Predicting Health Behaviour: A Social Cognition Approach. In: Conner, M., Norman, P. (ed.) Predicting Health Behaviour. Second ed. UK: Open University Press.

Conover, E. A. \& Jones, K. L. 2012. Safety concerns regarding binge drinking in pregnancy: a review. Birth Defects Res A Clin Mol Teratol, 94, 570-5.

Cooper ML, R. M., Skinner JB, Windle M 1992. Development and validation of a three-dimensional measure of drinking motives. Psychol Assess, 4, 123-132.

Crawford-Williams, F., Fielder, A., Mikocka-Walus, A. \& Esterman, A. 2015. A critical review of public health interventions aimed at reducing alcohol consumption and/or increasing knowledge among pregnant women. Drug Alcohol Rev, 34, 154-61.

Czeizel, A. E., Petik, D. \& Puho, E. 2004. Smoking and alcohol drinking during pregnancy. The reliability of retrospective maternal self-reported information. Cent Eur J Public Health, 12, 179-83.

Danielsson, M. \& Sundström, K. 2006. Chapter 6: reproductive health. Scand J Public Health Suppl, 67, 147-64.

Darlington, G. A. 2005. Explanatory Variables. In: Armitage, P., Colton, T. (ed.) Encyclopedia of Biostatistics. West Sussex: Wiley

Deci, E. L., Ryan, R. M. 1985. Intrinsic motivation and self-determination in human behavior, New York, Plenum

Del Boca, F. K. \& Darkes, J. 2003. The validity of self-reports of alcohol consumption: state of the science and challenges for research. Addiction, 98 Suppl 2, 1-12.

Devaux, M., F. Sassi 2015. Alcohol consumption and harmful drinking: Trends and social disparities across OECD countries. OECD Health Working Papers, 79.

Elek, E., Harris, SL., Squire, SM., Margolisa, M., Weber, MK., Dang, EP., Betsy Mitchell 2013. Women's Knowledge, Views, and Experiences Regarding 
Alcohol Use and Pregnancy: Opportunities to Improve Health Messages. American journal of health education, 44, 177-190.

Ernhart, C. B., Sokol, R. J., Martier, S., Moron, P., Nadler, D., Ager, J. W. \& Wolf, A. 1987. Alcohol Teratogenicity in the Human - a Detailed Assessment of Specificity, Critical Period, and Threshold. American Journal of Obstetrics and Gynecology, 156, 33-39.

Estabrooks, C. A., Derksen, L., Winther, C., Lavis, J. N., Scott, S. D., Wallin, L. \& Profetto-McGrath, J. 2008. The intellectual structure and substance of the knowledge utilization field: a longitudinal author co-citation analysis, 1945 to 2004. Implement Sci, 3, 49.

Ewles, L., Simnett, I. 2003. Promoting Helath - a practival guide, Edinburgh etc. Baillière Tindall

Floyd, LR., Sobell, M., Velasquez, MM., Ingersoll, K., Nettleman, M., Soboll, L., Mullen, PD, Ceperich, S., von Sterber, K., Bolton, B., Skarpness, B., Nagaraja, J. 2007. Preventing alcohol-exposed pregnancies: A randomized controlled trial. American Journal of Preventive Medicine. 31(1),1-10.

Gallestey , J. 2008. Validity. In: Boslaugh, S. (ed.) Encyclopedia of Epidemiology. SAGE Publications.

Gardner, B. 2014. A review and analysis of the use of 'habit' in understanding, predicting and influencing health-related behaviour. Health Psychol Rev, 1-19.

Gilinsky, A., Swanson, V. \& Power, K. 2011. Interventions delivered during antenatal care to reduce alcohol consumption during pregnancy: A systematic review. Addiction Research $\mathcal{E}$ Theory, 19, 235-250.

Göransson, M., Magnusson, A., Bergman, H., Rydberg, U. \& Heilig, M. 2003. Fetus at risk: prevalence of alcohol consumption during pregnancy estimated with a simple screening method in Swedish antenatal clinics. Addiction, 98, 1513-20.

Göransson, M., Magnusson, A. \& Heilig, M. 2006. Identifying hazardous alcohol consumption during pregnancy: implementing a research-based model in real life. Acta Obstet Gynecol Scand, 85, 657-62.

Gordon, R. S., Jr. 1983. An operational classification of disease prevention. Public Health Rep, 98, 107-9.

Graham, J. M., Jr., Hanson, J. W., Darby, B. L., Barr, H. M. \& Streissguth, A. P. 1988. Independent dysmorphology evaluations at birth and 4 years of age for children exposed to varying amounts of alcohol in utero. Pediatrics, 81, 772-8. 
Gray, R., Mukherjee, R. A. S. \& Rutter, M. 2009. Alcohol consumption during pregnancy and its effects on neurodevelopment: what is known and what remains uncertain. Addiction, 104, 1270-1273.

Greenhalgh, T., Robert, G., Bate, P. 2005. Diffusion of Innovations in Health Service Organisations: A Systematic Literature Review, Blackwell Publishing Ltd.

Grittner, U., Kuntsche, S., Gmel, G. \& Bloomfield, K. 2013. Alcohol consumption and social inequality at the individual and country levels-results from an international study. Eur J Public Health, 23, 332-9.

Grønkjær, M., Curtis, T., Crespigny, C. D. \& Delmar, C. 2011. Acceptance and expectance: Cultural norms for alcohol use in Denmark. Int J Qual Stud Health Well-being, 6.

Hanson, J. D., Winberg, A. \& Elliott, A. 2012. Development of a media campaign on fetal alcohol spectrum disorders for Northern Plains American Indian communities. Health Promot Pract, 13, 842-7.

Swedish National Institute of Public Health. 2014. Folkhälsan i Sverige Årsrapport 2014 [The public health in Sweden - yearly report 2014].

Helmersson-Bergmark, K. 2001. Svenskarna och alkoholen 2000. Stockholm:

Statens folkhälsoinstitut \& Centralförbundet för alkohol- och narkotikaupplysning.

Henderson, J., Gray, R. \& Brocklehurst, P. 2007. Systematic review of effects of low-moderate prenatal alcohol exposure on pregnancy outcome. BJOG, 114, 243-52.

Holmes, T. H. \& Rahe, R. H. 1967. The Social Readjustment Rating Scale. Journal of Psychosomatic Research, 11, 213-8.

Holmqvist, M. \& Nilsen, P. 2010. Approaches to assessment of alcohol intake during pregnancy in Swedish maternity care--a national-based investigation into midwives' alcohol-related education, knowledge and practice. Midwifery, 26, 430-4.

Härkönen, J. 2013. Not a wet generation but a wet nation. The dynamics of change and stasis in Finnish drinking culture from 1968-2008. Doctoral Thesis, University of Helsinki.

Jones, K. L. \& Smith, D. W. 1973. Recognition of the fetal alcohol syndrome in early infancy. Lancet, 302, 999-1001.

Jones, S. C. \& Telenta, J. 2012. What influences Australian women to not drink alcohol during pregnancy? Aust J Prim Health, 18, 68-73.

Joya, X., Friguls, B., Ortigosa, S., Papaseit, E., Martinez, S. E., Manich, A., Garcia-Algar, O., Pacifici, R., Vall, O. \& Pichini, S. 2012. Determination 
of maternal-fetal biomarkers of prenatal exposure to ethanol: a review. J Pharm Biomed Anal, 69, 209-22.

Järvinen, M. \& Room, R. 2007. Youth drinking cultures : European experiences, Aldershot, England; Burlington, VT, Ashgate.

Källmen, H., Wennberg, P., Ramstedt, M. \& Hallgren, M. 2015. Changes in alcohol consumption between 2009 and 2014 assessed with the AUDIT. Scand J Public Health, 43, 381-4.

Kaskutas, L. A. \& Graves, K. 1994. Relationship between cumulative exposure to health messages and awareness and behavior-related drinking during pregnancy. Am J Health Promot, 9, 115-24.

Kelly, Y. J., Sacker, A., Gray, R., Kelly, J., Wolke, D., Head, J. \& Quigley, M. A. 2012. Light drinking during pregnancy: still no increased risk for socioemotional difficulties or cognitive deficits at 5 years of age? J

Epidemiol Community Health, 66, 41-8.

Kesmodel, U. S., Bertrand, J., Stovring, H., Skarpness, B., Denny, C. H., Mortensen, E. L. \& Lifestyle During Pregnancy Study Group. 2012. The effect of different alcohol drinking patterns in early to mid pregnancy on the child's intelligence, attention, and executive function. BJOG, 119, 1180-90.

Krueger, R. A. \& Casey, M. A. 2009. Focus groups : a practical guide for applied research, Thousand Oaks, Calif., Sage Publications.

Krug, A., McNutt, L-A 2008. Prevalence. In: Boslaugh, S. (ed.) Encyclopedia of Epidemiology Thousand Oaks: SAGE.

Lally, P., Van Jaarsveld, C. H. M., Potts, H. W. W. \& Wardle, J. 2010. How are habits formed: Modelling habit formation in the real world. European Journal of Social Psychology, 40, 998-1009.

Leifman, H. 2002. Konsumtionsvanor och alkoholproblem In: Andréasson, S. (ed.) Den svenska supen i det nya Europa : nya villkor för alkoholprevention: en kunskapsöversikt. Stockholm: Folkhälsoinstitutet: Gothia distributör.

Leppo, A., Hecksher, D. \& Tryggvesson, K. 2014. 'Why take chances?' Advice on alcohol intake to pregnant and non-pregnant women in four Nordic countries. Health Risk $\mathcal{E}$ Society, 16, 512-529.

Lewis, S. J., Zuccolo, L., Davey Smith, G., Macleod, J., Rodriguez, S., Draper, E. S., Barrow, M., Alati, R., Sayal, K., Ring, S., Golding, J. \& Gray, R. 2012. Fetal alcohol exposure and IQ at age 8: evidence from a populationbased birth-cohort study. Plos One, 7, e49407.

Lincoln, Y. Guba, E. 1985. Naturalistic Inquiry, Beverly Hills, Sage.

Magnusson, Å., Goransson, M. \& Heilig, M. 2005. Unexpectedly high prevalence of alcohol use among pregnant Swedish women: failed 
detection by antenatal care and simple tools that improve detection. $J$ Stud Alcohol, 66, 157-64.

Magnusson, Å., Goransson, M. \& Heilig, M. 2007. Hazardous alcohol users during pregnancy: psychiatric health and personality traits. Drug Alcohol Depend, 89, 275-81.

Mäkelä, K. 1984. Permissible starting age for drinking in four Scandinavian countries. J Stud Alcohol, 45, 522-7.

Malet, L., de Chazeron, I., Llorca, P. M. \& Lemery, D. 2006. Alcohol consumption during pregnancy: An urge to increase prevention and screening. Eur J Epidemiol, 21, 787-788.

Manwell, L. B., Fleming, M. F., Mundt, M. P., Stauffacher, E. A. \& Barry, K. L. 2000. Treatment of problem alcohol use in women of childbearing age: Results of a brief intervention trial. Alcoholism-Clinical and Experimental Research, 24, 1517-1524.

Margetts, B., Vorster, H., Venter, C. 2003. Evidence-based nutrition: the impact of information and selection bias on the interpretation of individual studies. South African Journal of Clinical Nutrition, 16, 78-87.

May, P. A., Baete, A., Russo, J., Elliott, A. J., Blankenship, J., Kalberg, W. O., Buckley, D., Brooks, M., Hasken, J., Abdul-Rahman, O., Adam, M. P., Robinson, L. K., Manning, M. \& Hoyme, H. E. 2014. Prevalence and characteristics of fetal alcohol spectrum disorders. Pediatrics, 134, 855-66.

May, P. A., Blankenship, J., Marais, A. S., Gossage, J. P., Kalberg, W. O., Barnard, R., De Vries, M., Robinson, L. K., Adnams, C. M., Buckley, D., Manning, M., Jones, K. L., Parry, C., Hoyme, H. E. \& Seedat, S. 2013. Approaching the prevalence of the full spectrum of fetal alcohol spectrum disorders in a South African population-based study. Alcohol Clin Exp Res, 37, 818-30.

May, P. A., Fiorentino, D., Coriale, G., Kalberg, W. O., Hoyme, H. E., Aragon, A. S., Buckley, D., Stellavato, C., Gossage, J. P., Robinson, L. K., Jones, K. L., Manning, M. \& Ceccanti, M. 2011. Prevalence of children with severe fetal alcohol spectrum disorders in communities near Rome, Italy: new estimated rates are higher than previous estimates. Int J Environ Res Public Health, 8, 2331-51.

May, P. A. \& Gossage, J. P. 2011. Maternal risk factors for fetal alcohol spectrum disorders: not as simple as it might seem. Alcohol Res Health, $34,15-26$.

McCambridge, J. 2015. From question-behaviour effects in trials to the social psychology of research participation. Psychol Health, 30, 72-84. 
McCarthy, F. P., O'Keeffe, L. M., Khashan, A. S., North, R. A., Poston, L., McCowan, L. M., Baker, P. N., Dekker, G. A., Roberts, C. T., Walker, J. J. \& Kenny, L. C. 2013. Association between maternal alcohol consumption in early pregnancy and pregnancy outcomes. Obstet Gynecol, 122, 830-7.

McDonald, S. W., Hicks, M., Rasmussen, C., Nagulesapillai, T., Cook, J. \& Tough, S. C. 2014. Characteristics of women who consume alcohol before and after pregnancy recognition in a Canadian sample: a prospective cohort study. Alcohol Clin Exp Res, 38, 3008-16.

McGee Petrenko, C., Riley, EP. 2011. The effects of prenatal alcohol exposure on brain and behaviour. In: Preece, P. M., Riley, E P. (ed.) Alcohol, drugs and medication in pregnancy - the long-term outcome for the child. Plymouth: Mac Keith Press.

Mustonen, H., Makela, P. \& Huhtanen, P. 2007. People are buying and importing more alcohol than ever before. Where is it all going? DrugsEducation Prevention and Policy, 14, 513-527.

Neal, D. T. Wood, W. Quinn, JM. 2006. Habits - a repeat performance. Curr Directions Psychol Sci, 15, 198-202.

Neve, R. L., P. \& Drop, M. 2000. Changes in Alcohol Use and Drinking Problems in Relation to Role Transition in Different Stages of the Life Course. Substance Abuse, 21, 163-178.

Nilsen, P. 2009. Brief alcohol intervention to prevent drinking during pregnancy: an overview of research findings. Current Opinion in Obstetrics \& Gynecology, 21, 496-500.

Nilsen, P. 2015. Making sense of implementation theories, models and frameworks. Implement Sci, 10, 53.

Nilsen, P., Holmqvist, M., Bendtsen, P., Hultgren, E. \& Cedergren, M. 2010. Is questionnaire-based alcohol counseling more effective for pregnant women than standard maternity care? J Womens Health (Larchmt), 19, 161-7.

Nilsen, P., Holmqvist, M., Hultgren, E., Bendtsen, P. \& Cedergren, M. 2008. Alcohol use before and during pregnancy and factors influencing change among Swedish women. Acta Obstet Gynecol Scand, 87, 768-74.

Nilsen, P., Roback, K., Brostrom, A. \& Ellstrom, P. E. 2012a. Creatures of habit: accounting for the role of habit in implementation research on clinical behaviour change. Implement Sci, 7, 53.

Nilsen, P., Skagerstrom, J., Rahmqvist, M., Hultgren, E. \& Blomberg, M. 2012b. Alcohol prevention in Swedish antenatal care: effectiveness and 
perceptions of the Risk Drinking project counseling model. Acta Obstet Gynecol Scand, 91, 736-43.

Nybo-Andersen, A. M., Andersen, P. K., Olsen, J., Gronbaek, M. \& StrandbergLarsen, K. 2012. Moderate alcohol intake during pregnancy and risk of fetal death. Int J Epidemiol, 41, 405-13.

Nykjær, C., Alwan, N. A., Greenwood, D. C., Simpson, N. A., Hay, A. W., White, K. L. \& Cade, J. E. 2014. Maternal alcohol intake prior to and during pregnancy and risk of adverse birth outcomes: evidence from a British cohort. J Epidemiol Community Health, 68, 542-9.

O'Keeffe, L. M., Kearney, P. M., McCarthy, F. P., Khashan, A. S., Greene, R. A., North, R. A., Poston, L., McCowan, L. M., Baker, P. N., Dekker, G. A., Walker, J. J., Taylor, R. \& Kenny, L. C. 2015. Prevalence and predictors of alcohol use during pregnancy: findings from international multicentre cohort studies. BMJ Open, 5, e006323.

O'Leary, C., Zubrick, S. R., Taylor, C. L., Dixon, G. \& Bower, C. 2009. Prenatal alcohol exposure and language delay in 2-year-old children: the importance of dose and timing on risk. Pediatrics, 123, 547-54.

O'Leary, C. M. \& Bower, C. 2012. Guidelines for pregnancy: what's an acceptable risk, and how is the evidence (finally) shaping up? Drug Alcohol Rev, 31, 170-83.

Olegård, R., Sabel, K. G., Aronsson, M., Sandin, B., Johansson, P. R., Carlsson, C., Kyllerman, M., Iversen, K. \& Hrbek, A. 1979. Effects on the child of alcohol abuse during pregnancy. Retrospective and prospective studies. Acta Paediatr Scand Suppl, 275, 112-21.

Padmanabhan, R. \& Hameed, M. S. 1988. Effects of acute doses of ethanol administered at pre-implantation stages on fetal development in the mouse. Drug Alcohol Depend, 22, 91-100.

Palma, S., Pardo-Crespo, R., Mariscal, M., Perez-Iglesias, R., Llorca, J. \& Delgado-Rodriguez, M. 2007. Weekday but not weekend alcohol consumption before pregnancy influences alcohol cessation during pregnancy. Eur J Public Health, 17, 394-9.

Petkovic, G. \& Barisic, I. 2013. Prevalence of fetal alcohol syndrome and maternal characteristics in a sample of schoolchildren from a rural province of Croatia. Int J Environ Res Public Health, 10, 1547-61.

Ramstedt, M (ed.). Boman, U. Engdahl, B. Sohlberg, T. Svensson, J. 2010. Figures on alcohol 2010- a statistical yearly report from the monitor poroject Stockholm: Stockholms Universitet. [Tal om alkohol 2010 - en statistisk årsrapport från Monitorprojektet.] 
Ramstedt, M (ed)., Lindell, A. Raninen, J. 2013. Figures on alcohol 2012- a statistical yearly report from the monitor poroject [Tal om alkohol 2012Enstatistisk årsrapport från Monitorprojektet.] Stockholm: SoRAD. Rangmar, J. \& Falke, C. 2013. Fetal Alcohol Spectrum Disorders - psycosocial consequenses and preventive aspects on alcohol related birth defects. [Psykosociala konsekvenser av och preventiva aspekter på alkoholrelaterade fosterskador.] Report: Linnéuniversitetet, Nka Barn som anhöriga. http://www.anhoriga.se/nyheter/kunskapsoversikt-omalkoholrelaterade-fosterskador/.

Raninen, J., Livingston, M. \& Leifman, H. 2014. Declining trends in alcohol consumption among Swedish youth-does the theory of collectivity of drinking cultures apply? Alcohol Alcohol, 49, 681-6.

Pregnancy quality registry. 2013. Annual Review 2013. [Graviditetsregistret. 2013. Årsrapport 2013.] Avalible at:

https://www.medscinet.com/gr/app/uploads/hemsida/dokumentarkiv/ GR Årsrapport\%202013 20141113.pdf

Public Helath Agency of Sweden. 2014. The public health in Sweden - yearly report 2014 [Folkhälsoinstitutet. 2014. Folkhälsan i Sverige - Årsrapport 2014].

Riley, E. P., Infante, M. A. \& Warren, K. R. 2011. Fetal alcohol spectrum disorders: an overview. Neuropsychol Rev, 21, 73-80.

Robinson, M., Oddy, W. H., McLean, N. J., Jacoby, P., Pennell, C. E., de Klerk, N. H., Zubrick, S. R., Stanley, F. J. \& Newnham, J. P. 2010. Lowmoderate prenatal alcohol exposure and risk to child behavioural development: a prospective cohort study. Bjog-an International Journal of Obstetrics and Gynaecology, 117, 1139-1150.

Rogers, E. M. 2003. Diffusion of innovations, New York, Free press.

Room, R. \& Mäkelä, K. 2000. Typologies of the cultural position of drinking. J Stud Alcohol, 61, 475-83.

Ryan, R. M., Deci, E. L. 2000. Self-determination theory and the facilitation of intrinsic motivation, social development, and well-being. American Psychologist, 55, 68-78.

Sanders, J. L. 2011. Commentary: what might have been: Sullivan may have impacted modern prenatal alcohol research under different circumstances. Int J Epidemiol, 40, 283-5.

Satten, GA. Grummer-Strawn, L. 2005. Cross-Sectional Study In: Armitage, P. C., Theodore (ed.) Encyclopedia of Biostatistics. Chichester, West Sussex, England ; Hoboken, NJ: John Wiley. 
Sayal, K., Draper, E. S., Fraser, R., Barrow, M., Smith, G. D. \& Gray, R. 2013. Light drinking in pregnancy and mid-childhood mental health and learning outcomes. Archives of Disease in Childhood, 98, 107-111.

Sayal, K., Heron, J., Golding, J. \& Emond, A. 2007. Prenatal alcohol exposure and gender differences in childhood mental health problems: a longitudinal population-based study. Pediatrics, 119, e426-34.

SFS 2003:460. Lag (2003:460) om etikprövning av forskning som avser människor

SIRC 1998. Social and Cultural Aspect of Drinking - A report to the European Commission Oxford.

Skogerbø, A., Kesmodel, U. S., Wimberley, T., Stovring, H., Bertrand, J., Landro, N. I. \& Mortensen, E. L. 2012. The effects of low to moderate alcohol consumption and binge drinking in early pregnancy on executive function in 5-year-old children. BJOG, 119, 1201-10.

Sokol, R. J., Delaney-Black, V. \& Nordstrom, B. 2003. Fetal alcohol spectrum disorder. JAMA, 290, 2996-9.

Sood, B., Delaney-Black, V., Covington, C., Nordstrom-Klee, B., Ager, J., Templin, T., Janisse, J., Martier, S. \& Sokol, R. J. 2001. Prenatal alcohol exposure and childhood behavior at age 6 to 7 years: I. dose-response effect. Pediatrics, 108, E34.

Staff, J., Schulenberg, J. E., Maslowsky, J., Bachman, J. G., O'Malley, P. M., Maggs, J. L. \& Johnston, L. D. 2010. Substance use changes and social role transitions: proximal developmental effects on ongoing trajectories from late adolescence through early adulthood. Dev Psychopathol, 22, 917-32.

Strandberg-Larsen, K., Rod Nielsen, N., Nybo Andersen, A. M., Olsen, J. \& Gronbaek, M. 2008. Characteristics of women who binge drink before and after they become aware of their pregnancy. Eur J Epidemiol, 23, 56572.

Stratton, K. Howe, C. Battaglia, F (ed.). 1996. Fetal Alcohol Syndrome - diagnosis, epidemiology, prevention and treatment, Washington, D.C., National Academy Press.

Streissguth, A., Grant, TM. 2011. prenatal and postnatal intervention strategies for alcohol-abusing mothers in pregnancy In: Preece, PM. Riley, EP. (ed.) Alcohol, drugs and medication in pregnancy - the long term outcome for the child. London, UK: Mac Keith Press.

Strevens, H. F., H. Westergren, C. Knutson, B. Ny, P. 2008. Medicinskt basprogram i samband med graviditet. In: Mattson, L.-Å. (ed.) 
Mödrahälsovård, Sexuell och Reproduktiv Hälsa intressegruppen för mödrahälsovård inom SFOG.

Sulik, K., O'Leary-Moore, SK., Godin, EA., Parnell S E 2011. Normal and abnormal embryogenesis of the mammalian brain. In: Preece P M, R. E. P. (ed.) Alcohol, drugs and medication in pregnancy - the long-term outcome for the child. London: Mac Keith Press.

Sullivan, W. C. 1899. A Note on the Influence of Maternal Inebriety on the Offspring BJP, 45, 489-503.

Swedish National Borad of Helath and Welfare. 2013. Pregnancies, Deliveries and Newborn Infants [Socialstyrelsen 2013. Graviditet, förlossningar och nyfödda barn - medicinska födelseregistret 1973-2013, assisterad befruktning 1991-2012]. Official statistics of Sweden. Statitics - Helath and Medical care. Avalible at:

http://www.socialstyrelsen.se/publikationer2014/2014-12-19

Tamaki, T., Kaneita, Y., Ohida, T., Harano, S., Yokoyama, E., Osaki, Y., Takemura, S. \& Hayashi, K. 2008. Alcohol consumption behavior of pregnant women in Japan. Prev Med, 47, 544-9.

The Swedish Council for Information on Alcohol and Other Drugs (CAN). 2014. Drug trends in Sweden 2014. Stockholm: Centralförbundet för alkohol- och narkotikaupplysning. [Centralförbundet för alkohol- och narkotikaupplysning. 2014. Drogutvecklingen i Sverige 2014.]

The Swedish Council for Information on Alcohol and Other Drugs (CAN). 2012. Drug trends in Sweden 2011. Stockholm: Centralförbundet för alkohol- och narkotikaupplysning 2012. [Centralförbundet för alkoholoch narkotikaupplysning. 2014. Drogutvecklingen i Sverige. 2011]

The Swedish Medical Birth Register 1973-2012. OFFICIAL STATISTICS OF SWEDEN. Avalible at: www.socialstyrelsen.se

Thomas, R. M. 2003. Blending qualitative $\mathcal{E}$ quantitative research methods in theses and dissertations, Thousand Oaks, Calif., Corwin Press.

Tough, S., Tofflemire, K., Clarke, M. \& Newburn-Cook, C. 2006. Do women change their drinking behaviors while trying to conceive? An opportunity for preconception counseling. Clin Med Res, 4, 97-105.

Tydén, T., Stern, J., Nydahl, M., Berglund, A., Larsson, M., Rosenblad, A. \& Aarts, C. 2011. Pregnancy planning in Sweden--a pilot study among 270 women attending antenatal clinics. Acta Obstet Gynecol Scand, 90, 408-12.

Törnqvist, C. 2007. Twenty then - today about thirty-five. The meaning of alcohol in a life course perspective. Nordic studies on alcohol and drugs, 24, 563-587. 
Törrönen, J. \& Tryggvesson, K. 2015. Alcohol, health and reproduction. An analysis of Swedish public health campaigns against drinking during pregnancy. Critical Discourse Studies, 12, 57-77.

Underbjerg, M., Kesmodel, U. S., Landro, N. I., Bakketeig, L., Grove, J., Wimberley, T., Kilburn, T. R., Svaerke, C., Thorsen, P. \& Mortensen, E. L. 2012. The effects of low to moderate alcohol consumption and binge drinking in early pregnancy on selective and sustained attention in 5year-old children. BJOG, 119, 1211-21.

Wallace, R. 2006. Prevention. In: Breslow, L. (ed.) Encyclopedia of Public Health. New York: Macmillan Reference USA.

Warren, K. R. \& Li, T. K. 2005. Genetic polymorphisms: impact on the risk of fetal alcohol spectrum disorders. Birth Defects Res A Clin Mol Teratol, 73, 195-203.

Webster, J., Linnane, J. W. J., Dibley, L. M., Hinson, J. K., Starrenburg, S. E. \& Roberts, J. A. 2000. Measuring social support in pregnancy: Can it be simple and meaningful? Birth-Issues in Perinatal Care, 27, 97-101.

Verplanken, B., Aarts, H. \& VanKnippenberg, A. 1997. Habit, information acquisition, and the process of making travel mode choices. European Journal of Social Psychology, 27, 539-560.

Verplanken, B. \& Faes, S. 1999. Good intentions, bad habits, and effects of forming implementation intentions on healthy eating. European Journal of Social Psychology, 29, 591-604.

Verplanken B, O. S. 2003. Reflections on past behavior: a self-report index of habit strength. J Appl Soc Psychol, 33, 1313-1330.

Verplanken, B. \& Velsvik, R. 2008. Habitual negative body image thinking as psychological risk factor in adolescents. Body image, 5, 133-40.

WHO 1986. Ottawa Charter for Health Promotion. Geneva, Switzerland:

World Health Organization.

WHO 2014. Global status report on alcohol and health 2014. Geneva, Switzerland: World Health Organization.

Wibeck, V., Abrandt-Dahlgren, M. \& Öberg, G. 2007. Learning in focus groups: an analytical dimension for enhancing focus group research Qualitative Research in Psychology, 7, 249-267.

Windham, G. C., Von Behren, J., Fenster, L., Schaefer, C. \& Swan, S. H. 1997. Moderate maternal alcohol consumption and risk of spontaneous abortion. Epidemiology, 8, 509-14.

Wood, W. \& Neal, D. T. 2007. A new look at habits and the habit-goal interface. Psychol Rev, 114, 843-63. 
Wurst, F. M., Kelso, E., Weinmann, W., Pragst, F., Yegles, M. \& Poromaa, I. S. 2008. Measurement of direct ethanol metabolites suggests higher rate of alcohol use among pregnant women than found with the AUDIT - a pilot study in a population-based sample of Swedish women. American Journal of Obstetrics and Gynecology, 198.

Vygotsky, L. 1978. Mind in Society: The Development of Higher Psychological Processes, Cambridge, MA, Harvard University Press 


\section{APPENDICES}

Appendix A: Baseline questionnaire, Study II

Appendix B: Follow-up questionnaire, Study II

Appendix C: Questionnaire, Study III

Appendix D: Questionnaire A, Study IV

Appendix E: Questionnaire B, Study IV

Appendix F: Interview-guide, Study V 

Appendix 



\section{Riskbruks ENKÄT \\ Till dig som jobbar som Barnmorska inom MVC}

Riskbruk av alkohol avser en konsumtion som på sikt kan leda till hälsoproblem eller som har gett upphov till detta. I definitionen utesluts således besökare som har ett missbruk eller utvecklat ett alkoholberoende.

1. Kön

$\square$ Kvinna

Man

\section{Vad har Du för tjänstgöring?}

Barnmorska inom mödrahälsovården

$\square$ Barnmorska inom familjecentral, motsv.

Arbetar inte inom mödrahälsovården just nu

Annat

\section{När är Du född?}

(årtal)

5. Inom vilket Landsting/region arbetar Du i första hand?

$\begin{array}{ll}\square \text { Blekinge } & \square \text { Jönköping } \\ \square \text { Dalarna } & \square \text { Kalmar } \\ \square \text { Gotland } & \square \text { Kronoberg } \\ \square \text { Gävleborg } & \square \text { Norrbotten } \\ \square \text { Halland } & \square \text { Skåne } \\ \square \text { Jämtland } & \\ \text { 6. Ange storleken på den ort inom vilken } \\ \quad \text { din mottagning är placerad } \\ \square \text { Glesbygd } \\ \square \text { Mindre/mellanstor stad } \\ \square \text { Storstad (Stockholm, Göteborg, Malmö) }\end{array}$

8. Hur många inskrivna träffar Du i genomsnitt per vecka? Skatta utifrån det senaste året.

$\begin{array}{ll}\text { Enskilt } & \text { I grupp } \\ \square 0-19 & \square 0-19 \\ \square 20-39 & \square 20-39 \\ \square 40-59 & \square 40-59 \\ \square \geq 60 & \square \geq 60\end{array}$

\section{Stockholm}

Södermanland

$\square$ Uppsala

Värmland

Västerbotten

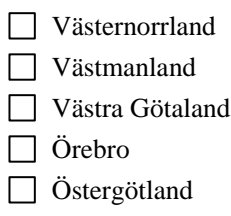

$\square$ Västernorrland

$\square$ Västmanland

$\square$ Västra Götaland

Östergötland

\section{Ange din mottagningsstorlek}

Antal barnmorskor som arbetar med mödrahälsovård vid din mottagning, omräknat till heltider:

\section{Vilken driftsform har din enhet?}

$\square$ Offentlig regi

$\square$ Privat regi 
10. Hur viktigt anser Du det är med information och rådgivning inom olika livsstilsområden till de inskrivna på mödrahälsovården?

$\begin{array}{lccc} & \text { Mycket viktigt } & & \text { Inget viktigt } \\ \text { Rökning: } & \square & \square & \square \\ \text { Fysisk inaktivitet: } & \square & \square & \square \\ \text { Övervikt: } & \square & \square & \square \\ \text { Stress: } & \square & \square & \square \\ \text { Riskbruk av alkohol: } & \square & \square & \square\end{array}$

11. Hur informerar Du oftast om alkohol och graviditet i din verksamhet?

Markera endast 1 svarsalternativ

Enskilt, endast med kvinnan

Enskilt, med båda blivande föräldrarna

I grupp

Både enskilt och i grupp
12. I vilken form ger Du oftast information om alkohol under graviditet?

Markera endast 1 svarsalternativ

Muntligt

Skriftligt

Både muntligt och skriftligt

Film/dvd

Annat:

13. Hur viktigt anser Du att det är att identifiera s.k. riskbruk av alkohol under graviditet?

Mycket viktigt

$\square$ Viktigt

$\square$ Ej viktigt

Ingen åsikt

14. Använder Du något särskilt formulär för att bedöma om kvinnan haft en riskkonsumtion av alkohol före graviditeten?

Om formulär använts ange vilket/vilka:

$\mathrm{Ja}$

Hur görs bedömningen:

Nej, gör en bedömning på annat sätt

Nej, gör ingen bedömning alls

15. Vad gör Du vanligen om Du identifierar en kvinna som haft ett riskbruk av alkohol innan hon blev gravid?

Markera endast 1 svarsalternativ

$\square$ Informerar allmänt om hälsomässiga konsekvenser av riskbruk

Påbörjar ett motiverande samtal i syftet att säkra en alkoholfri graviditet

Hänvisar till annan personal inom vårdcentralen som genomför ett motiverande samtal

$\square$ Hänvisar till annan instans utanför vårdcentralen t. ex socialtjänst, beroendeklinik 
16. Finns handlingsplan på mottagningen för vidare handläggning av inskrivna med etablerad missbruk/beroende av alkohol?

Observera att frågan inte innefattar patienter med ett riskbruk

$$
\square \text { Jej }
$$

17. Har Du tillgång till specialist- och stödresurser för patienter med missbruk/beroende?

$$
\text { Om ja, vilka }
$$

18. Har Du regelbunden samverkan med andra aktörer, t ex BVC, socialtjänst, kvinnoklinik?

$$
\text { Om ja, vilken/vilka aktörer? }
$$

$\square \mathrm{Ja}$

$\square$ Nej

19. Hur upplever Du som barnmorska det är att diskutera alkohol med din patient/besökare?

Lätt att tala om, gör det gärna

Ja Nej Vet ej

Svårt att tala om men gör det ändå

Svårt att tala, vill helst slippa

20. Hur uppskattar Du dina nuvarande kunskaper beträffande identifiering av inskrivna med riskbruk av alkohol?

$\square$ Mycket bra
$\square$ Bra
$\square$ Ganska dåliga
$\square$ Mycket dåliga

21. Vad anser Du om dina kunskaper när det gäller alkohol och graviditet?

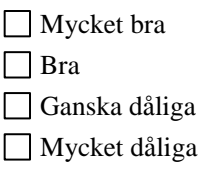

22. Hur mycket fortbildning under din yrkesverksamma tid har Du fått när det gäller hantering av riskbruk av alkohol?
$\square$ Ingen
1-2 dagar
$<4$ timmar
$\square$ dagar
halvdag
> 3 dagar

Ange vilken utbildning Du har genomgått:

23. Hur mycket tid skulle Du vilja avsätta under ett år för fortbildning om riskbruk av alkohol?

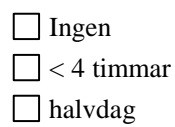

$$
\begin{aligned}
& \square \text { 1-2 dagar } \\
& \square 3 \text { dagar } \\
& \square>3 \text { dagar }
\end{aligned}
$$


24. Ta ställning till följande påståenden om vad som skulle kunna öka din insats beträffande identifikation av och rådgivning till kvinnor med riskbruk av alkohol:

Mer faktakunskap om hur Stämmer Stämmer Stämmer Stämmer Vet ej helt ganskabra mindre bra inte alls

alkoholen påverkar graviditeten

Mer kunskap om enkla skriftliga screeningsinstrument

Mer kunskap om samtalsmetoder vid alkoholrelaterade problem

Större tillgång till skriftlig patientinformation till gravida

Större möjlighet att avsätta tid för extra barnmorskebesök när kvinnor med riskbeteende identifieras

Tydliga riktlinjer från nationell nivå om vad som ingår i vårt uppdrag/arbete med riskbrukspatienter

Tydliga beslut på ledningsnivå om vad som ingår i vårt uppdrag/arbete med riskbrukspatienter

Bättre möjligheter att i svåra fall få stöd och handledning från specialmottagning

Väl utvecklade lokala handlingsplaner för hur frågan om alkohol tas upp med blivande föräldrar

25. Det kan finnas skäl att uppmärksamma den inskrivnas alkoholkonsumtion under tiden före graviditet. Det finns flera alternativ till vad som kan anses som gräns för riskfri alkoholkonsumtion per vecka för kvinnor som inte är gravida. När anser Du att en frisk ej gravid kvinna respektive frisk man är riskkonsument?

\section{Med ett standardglas menas något av detta:}

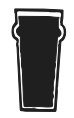

$50 \mathrm{cl}$ folköl

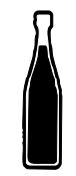

33 cl starköl

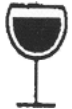

$15 \mathrm{cl}$ vin

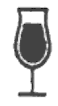

8 cl starkvin

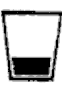

$4 \mathrm{cl}$ starksprit

Antal standard glas för män: glas per vecka Vet ej

Antal standard glas för kvinnor (ej gravida): glas per vecka

ÖVRIGA SYNPUNKTER: 
Appendix 



\section{ENKÄT OM ALKOHOL- OCH TOBAKSFÖREBYGGANDE ARBETE FÖR DIG SOM ÄR BARNMORSKA INOM MÖDRAVARDEN}

Riskbruk av alkohol avser en konsumtion som på sikt kan leda till hälsoproblem eller som har gett upphov till detta. I definitionen utesluts således besökare som har ett missbruk eller utvecklat ett alkoholberoende. Enkäten avslutas med några frågor om tobaksförebyggande arbete.

I. Kön

$\square$ Kvinna

Man

\section{Vad har Du för tjänstgöring?}

Barnmorska inom mödrahälsovården

Arbetar inte inom mödrahälsovården just nu

Annan:
2. När är Du född?

(årtal)

\section{Hur länge har Du arbetat inom} mödrahälsovården?

$\square<1$ år
$\square$ 1-2 år
$\square$ 3-5 år
$\square$ 6-10 år
$\square$ 11-20år
$\square>20$ år

5. Är Din mottagning knuten till en familjecentral eller familjecentralsliknande verksamhet $\square$ Ja $\quad \square$ Nej

6. Inom vilket Landsting/region arbetar Du i första hand?

$\begin{array}{llll}\square \text { Blekinge } & \square \text { Jönköping } & \square \text { Stockholm } & \square \text { Västernorrland } \\ \square \text { Dalarna } & \square \text { Kalmar } & \square \text { Södermanland } & \square \text { Västmanland } \\ \square \text { Gotland } & \square \text { Kronoberg } & \square \text { Uppsala } & \square \text { Västra Götaland } \\ \square \text { Gävleborg } & \square \text { Norrbotten } & \square \text { Värmland } & \square \text { Örebro } \\ \square \text { Halland } & \square \text { Skåne } & \square \text { Västerbotten } & \square \text { Östergötland }\end{array}$

7. Ange storleken på den ort inom vilken Din mottagning är placerad

$\square$ Glesbygd

$\square$ Mindre/mellanstor stad

$\square$ Storstad (Stockholm, Göteborg, Malmö)

9. Hur många inskrivna träffar Du i genomsnitt per vecka? Skatta utifrån det senaste året.

$\begin{array}{ll}\text { Enskilt } & \text { I grupp } \\ \square 0-9 & \square 0-9 \\ \square \text { 10-19 } & \square \text { 10-19 } \\ \square \text { 20-39 } & \square \text { 20-39 } \\ \square \text { 40-59 } & \square \text { 40-59 } \\ \square \geq 60 & \square \geq 60\end{array}$

\section{Ange Din mottagningsstorlek}

Antal barnmorskor som arbetar med mödrahälsovård vid din mottagning, omräknat till heltider:

\section{I0. Vilken driftsform har Din enhet?}

Offentlig regi

Privat regi 
I I. Hur viktigt anser Du det är med information och rådgivning inom olika livsstilsområden till de inskrivna på mödrahälsovården?

\section{Rökning:}

Fysisk inaktivitet:

Övervikt:

Stress:

Riskbruk av alkohol:

\section{Mycket viktigt}

$\begin{array}{ll}\square & \square \\ \square & \square \\ \square & \square \\ \square & \square \\ \square & \square\end{array}$

13. I vilken form ger Du oftast information om alkohol under graviditet?

Markera ett svarsalternativ

Muntligt

Skriftligt

Både muntligt och skriftligt

Film/DVD

Annat:

14. Hur viktigt anser Du att det är att identifiera s.k. riskbruk av alkohol under graviditet?

Mycket viktigt

$\square$ Viktigt

$\square$ Ej viktigt

Ingen åsikt

15. Använder Du något särskilt formulär för att bedöma om kvinnan haft en riskkonsumtion av alkohol före graviditeten?

$\mathrm{Ja}$

Om formulär använts ange vilket/vilka:

Hur görs bedömningen:

Nej, gör en bedömning på annat sätt

Nej, gör ingen bedömning alls

16. Vad gör Du vanligen om Du identifierar en kvinna som haft ett riskbruk av alkohol innan hon blev gravid?

\section{Markera ett svarsalternativ}

$\square$ Informerar allmänt om hälsomässiga konsekvenser av riskbruk

$\square$ Påbörjar ett motiverande samtal i syftet att säkra en alkoholfri graviditet

$\square$ Hänvisar till annan personal inom vårdcentralen som genomför ett motiverande samtal

Hänvisar till annan instans utanför vårdcentralen t. ex socialtjänst, beroendeklinik

17. Hur stor andel kvinnor tror eller bedömer Du dricker alkohol någon gång under sin graviditet (efter att graviditeten har bekräftats)? Gör en enkel skattning i procent utifrån din uppfattning!

Jag tror att ungefär \% av gravida kvinnor i Sverige dricker alkohol någon gång under sin graviditet (efter att graviditeten har bekräftats). 
18. Hur uppskattar Du dina nuvarande kunskaper beträffande identifiering av inskrivna med riskbruk av alkohol?

Mycket bra $\square$ Bra $\square$ Ganska dåliga $\square$ Mycket dåliga

19. Vad anser Du om dina kunskaper när det gäller alkohol och graviditet?
Mycket bra
$\square$ Bra
Ganska dåliga
Mycket dåliga

20. Hur mycket fortbildning beträffande hantering av riskbruk av alkohol har Du fått, totalt sett, under hela Din yrkesverksamma tid?
Ingen
$\square<4$ timmar $\square$ halvdag
1-2 dagar
3 dagar
$>3$ dagar

21. Vilket innehåll har den utbildning haft som du deltagit i under hela Din yrkesverksamma tid? Flera alternativ är möjliga!

$\square$ Motiverande samtal (MI)

$\square$ Rådgivning och att ge information kring alkoholvanor

Riskbruk av alkohol

Övrigt:
Biologiska markörer

Screening

AUDIT

Andra formulär än AUDIT

22. Har du under den senaste treårsperioden deltagit i någon form av utbildning (föreläsning, kurs, information, etc.) kring alkoholfrågor, riskbruk och liknande?

$\square$ Ja

$\square$ Nej

Om du svarat nej kan du hoppa direkt till de avslutande frågorna, \#26-29!
Om nej, varför inte? Flera alternativ är tillåtna!

$\square$ Sådan utbildning har ingen/liten relevans för mig

$\square$ Är inte intresserad eller motiverad

$\square$ Arbetsgivaren stödjer inte mitt deltagande

$\square$ Anser mig kunna dessa frågor tillräckligt redan

\section{Hur mycket utbildning har Du fått i motiverande samtal (MI) de senaste fyra åren?}

\footnotetext{
$\square$ Ingen

$\square$ Mindre än en dag

1-2 dagar

3 dagar eller mer

$\square$ Vet ej
}

24. Varför deltog Du i utbildning om alkoholfrågor, riskbruk och liknande under den senaste treårsperioden? Hur pass väl stämmer följande påståenden?

Stämmer helt $\begin{array}{r}\text { Stämmer } \\ \text { till stor del }\end{array} \quad \begin{array}{r}\text { Stämmer } \\ \text { till liten del }\end{array} \quad$ Stämmer inte alls

Jag tog själv initiativet till att delta

Jag var intresserad av ämnet/innehållet

Jag utgick från att jag skulle ha

praktisk nytta av det jag skulle lära mig

Jag blev uppmanad/uppmuntrad av chef att delta

Jag blev uppmanad/uppmuntrad av kollega att delta till liten del

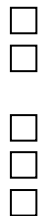


25. Vad är ditt helhetsintryck av de utbildningar kring alkoholfrågor, riskbruk och liknande Du deltagit i under den senaste treårsperioden?

$\begin{array}{lccc}\text { Stämmer helt } & \begin{array}{c}\text { Stämmer } \\ \text { till stor del }\end{array} & \begin{array}{c}\text { Stämmer } \\ \text { till liten del }\end{array} & \text { Stämmer inte alls } \\ \text { Den har känts angelägen/relevant för mig } & \square & \square \\ \text { Den har innehållit mycket som varit nytt för mig } & \square\end{array}$

26. Har Ditt arbete med alkoholfrågor och riskbruk förändrats under den senaste treårsperioden, oavsett om Du deltagit i utbildning kring alkoholfrågor, riskbruk och liknande eller ej?

\begin{tabular}{|c|c|c|}
\hline tämmer hel & $\begin{array}{r}\text { Stämmer } \\
\text { till stor del }\end{array}$ & $\begin{array}{c}\text { Stämmer } \\
\text { till liten del }\end{array}$ \\
\hline
\end{tabular}

Jag har blivit bättre på att initiera samtal kring alkohol med klienter

Jag har blivit bättre på att informera, ge råd eller samtala kring alkohol med klienter

Jag frågar fler av de klienter jag möter om deras alkoholvanor än tidigare

Jag initierar samtal kring alkohol med klienter på ett nytt sätt jämfört med tidigare

Jag informerar, ger råd eller samtalar kring alkohol med klienter på ett nytt sätt jämfört med tidigare

Jag har börjat ifrågasätta hur jag ska informera, ge råd eller samtala kring alkohol med klienter

Jag har börjat ifrågasätta varför jag ska ge råd, informera eller samtala kring alkohol med klienter

\section{Hur vanligt är det att Du erbjuder föräldrar följande?}

Alltid Ofta Ibland Sällan Aldrig

Information om passiv rökning och hur barnet skyddas

Överlämnar skriftligt material om rökning

28. Hur vanligt är det att Du erbjuder en tobaksbrukande förälder följande hjälp?

Alltid Ofta Ibland Sällan Aldrig

Bedömer motivation och diskuterar ett eventuellt stopp

Ger enkla råd om att sluta

Erbjuder tobaksavvänjning

Hänvisar till tobaksavvänjare på min vårdcentral/enhet

Remitterar till extern tobaksavvänjare
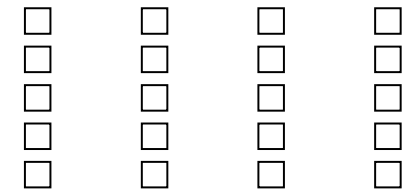

29. Är det lokala behovet av tobaksavvänjning tillgodosett (för de föräldrar/patienter som behöver detta) förutom de insatser Du kan bidra med?

Helt Till stor del Till liten del Inte alls

$\square \quad \square \quad \square \quad \square$


Appendix 



\section{$E N K \ddot{A} T O M$ \\ MO̊DRAHÅLSOVÅRENS ARBETE $\mathrm{OCH}$ \\ BESÖKARNAS ALKOHOLKONSUMTION}

Denna enkät handlar om dina åsikter om mödrahälsovårdens information och rådgivning och om alkoholkonsumtion före och under graviditet. Enkäten delas ut till alla gravida som besöker mödrahälsovården på utvalda mottagningar under en viss tid.

Du svarar helt anonymt. Inga svar redovisas så att enskilda personer kan identifieras. Vi är tacksamma om du tar dig tid och besvarar frågorna så noggrant och ärligt som möjligt. Frågorna tar cirka 5-10 minuter att svara på.

Informationen ska användas för att utveckla mödrahälsovårdens arbete. Svaren kommer också att ligga till grund för vetenskapliga artiklar.

Vi som genomför studien är Janna Malmsten och Per Nilsen på Linköpings universitet, Hiördis Högberg, barnmorska i Malmö och Eva-Karin Envall på Folkhälsoinstitutet. Vill du veta mer om undersökningen eller hur du ska besvara enkäten, får du gärna kontakta oss på telefon eller via e-post. Du kan också ta kontakt med personal på din mödrahälsovårdsmottagning.

Janna Malmsten

janna.malmsten@liu.se

013-22 3002
Per Nilsen

per.nilsen@liu.se

013-221547 


\section{Hur gammal är du?}

19 år eller yngre

$\square$ 20-24 år

25-29 år

30-34 år

35-39 år

40 år eller äldre

2. Vilken är din högsta utbildning? Om du studerar för närvarande, kan du kryssa $i$ den utbildning du går nu!

Grundskola

2-årigt gymnasium eller yrkesskola

3-4-årigt gymnasium

$\square$ KY eller folkhögskola

$\square$ Universitet/högskola, mindre än 3 år

Universitet/högskola, 3 år eller längre tid

Annan utbildning:

3. Vad hade du för sysselsättning när du blev gravid?

Jobbade

$\square$ Studerade, praktiserade

Föräldra- eller tjänstledig

Arbetslös

$\square$ Sjukskriven

Annat:

\section{Civilstånd}

Gift eller sammanboende

Särbo

Ensamstående (singel)

\section{Har du fött barn tidigare?}

Ja

$\square \mathrm{Nej}$

6. Vilken graviditetsvecka är du i nu? Gör en uppskattning om du är osäker! Vecka:

7. Hur många besök på mödrahälsovården har du varit på under din nuvarande graviditet, inklusive dagens möte? Räkna inte med ultraljudstillfället.

$1-2$

$\square 3-4$

5-6

$\square 7$ eller mer 


\section{Har du giort ett aktivt val för att była barnmorska någon gång under din nuvarande graviditet?}

$\square \mathrm{Ja}$

$\square \mathrm{Nej}$

\section{Hur stämmer följande påståenden med din uppfattning om mödrahälsovårdens insatser som helhet under din nuvarande graviditet?

Stämmer
helt $\quad \begin{gathered}\text { Stämmer } \\ \text { inte alls }\end{gathered}$

Jag är helt nöjd med mödrahälsovårdens insatser för mig

Det finns saker i mödrahälsovårdens insatser som kunde vara bättre

Den tid mödrahälsovården har ägnat mig är definitivt tillräcklig

Jag har inte haft så mycket kontakt med mödrahälsovården som jag önskat Personalen har förklarat allt för mig om varför olika

undersökningar och tester genomförs

Personalen kunde ha lyssnat mer uppmärksamt på mig

Personalen har behandlat mig med största respekt/värdighet

Personalen kunde ha varit vänligare och/eller tagit mer hänsyn till mina känslor

Jag har väldigt stort förtroende för de personer jag har

haft kontakt med i mödrahälsovården

Jag är lite tveksam till kunskapsnivån hos en del i mödrahälsovården Mödrahälsovårdens insatser för mig gör att jag slipper oro och osäkerhet Det finns vissa hälsofrågor som jag tycker mödrahälsovården inte har uppmärksammat tillräckligt

10. Vad anser du om mödrahälsovårdens information, under din nuvarande graviditet, om riskerna med att dricka alkohol under graviditeten?

Instämmer Instämmer Instämmer Instämmer Har inte fått helt till stor del till viss del inte info om detta

Jag har fått tillräckligt med information om riskerna med att dricka alkohol under graviditeten

Informationen jag har fått om riskerna med att dricka alkohol under graviditet har varit tydlig

Jag fick informationen om riskerna med att dricka alkohol tillräckligt tidigt i graviditeten

Informationen jag har fått om riskerna med att dricka alkohol under graviditet har varit lätt att förstå 


\section{Hur uppfattar du samtalen om alkohol som du har haft med barnmorskor under din nuvarande graviditet? Hoppa över frågan om du inte haft ett sådant samtal än.}

$\begin{array}{clll}\begin{array}{c}\text { Instämmer } \\ \text { helt }\end{array} & \begin{array}{l}\text { Instämmer } \\ \text { till stor del }\end{array} & \begin{array}{c}\text { Instämmer } \\ \text { till viss del }\end{array} & \begin{array}{c}\text { Instämmer } \\ \text { inte }\end{array}\end{array}$

Jag kommer ihåg innehållet väl

Jag har fått ny kunskap

Barnmorskan talade på ett bra sätt

Samtalet/samtalen har varit engagerande

Samtalet/samtalen har varit påträngande

Barnmorskan var professionell/kunnig

Samtalet om alkohol tog lagom mycket tid $\mathrm{i}$ anspråk

Barnmorskan lyssnade uppmärksamt på mig

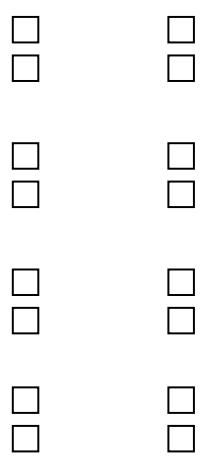

\section{Hur drack du alkohol året FÖRE graviditeten?}

Jag drack ingen alkohol $\rightarrow$ hoppa till fråga $18 !$

\section{Jag drack alkohol...}

...som ett sätt att fira

...för att koppla av

...för att jag gillade känslan

...därför att det var vad mina vänner gjorde när vi träffades

...för att glömma bekymmer

...därför att det var spännande

...för att passa in

...för att känna mig mer självsäker

...för att bli full
Aldrig eller nästan aldrig

Ibland

Ofta

Alltid eller nästan alltid

...därför att det förväntades vid vissa tillfällen

...därför att det hiälpte när jag kände mig deprimerad eller nervös

...därför att det var roligt

...därför att det gjorde sociala tillställningar trevligare

...för att jag blev gladare när jag var på dåligt humör

...därför att det fick mig att känna mig bra
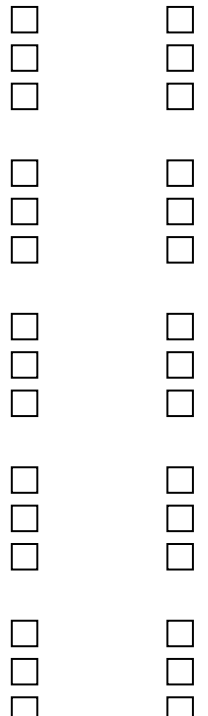
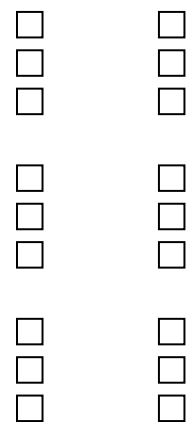
13. Hur väl stämmer följande påståenden för dig om du utgår från en typisk (normal) vecka, måndag-söndag, under tiden FÖRE graviditeten?

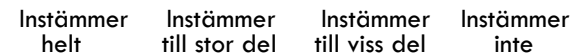

Att dricka alkohol någon eller några gånger ingick i mina vanor eller rutiner en typisk vecka

Jag drack alkohol någon eller några gånger under en typisk vecka utan att fundera så mycket på det

Det krävde viss ansträngning att inte dricka alkohol någon gång under en typisk vecka

Jag hade druckit alkohol någon eller några gånger per vecka under en längre tid

Det kändes konstigt att inte alls dricka alkohol någon gång en typisk vecka

Fråga 14 och 18 handlar om hur många standardglas man dricker - frågorna hänvisar till bilden nedan. 1 standardglas motsvarar något av följande:

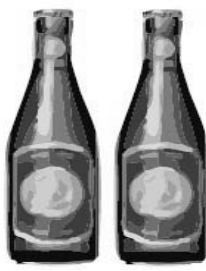

2 sł 33 cl lättöl

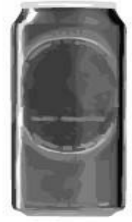

50 cl folköl
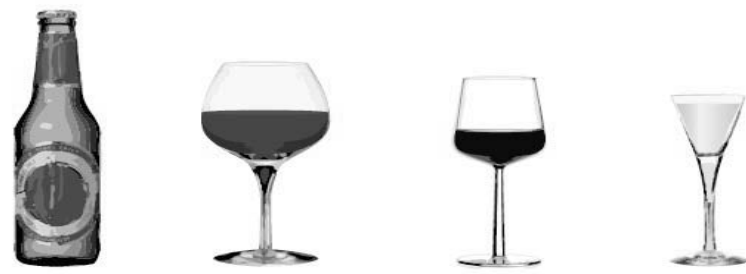

33 cl starköl/ 1 litet glas röłt / starkcider/alkoläsk vitt vin $(15 \mathrm{cl})$
8 cl starkvin

4 cl sprit

\section{Vi ber dig att uppskatta din alkoholkonsumtion året INNAN graviditeten blev känd} för dig!

A) Hur ofta drack du alkohol före graviditeten?

1 gång i månaden eller mer sällan

2-3 gånger i veckan

2-4 gånger i månaden

4 gånger i veckan eller oftare

B) Hur många standardglas drack du en typisk dag då du drack alkohol före graviditeten?

$\square 1$ glas

2 glas

3-4 glas

$\square$ 5-6 glas

7-9 glas

10 eller fler glas

C) Hur ofta drack du 4 standardglas eller mer vid ett och samma tillfälle före graviditeten?

$\square$ Aldrig

Mer sällan än 1 gång i månaden

Varje månad
2-3 gånger i månaden

Varje vecka

Dagligen eller nästan varje dag 


\section{Har du minskat din alkoholkonsumtion i samband med din graviditet? \\ Ja \\ Nej $\rightarrow$ hoppa till fråga 18 !}

\section{När minskade du din alkoholkonsumtion?}

\section{När jag planerade att bli gravid}

När jag blev medveten om att jag var gravid

När jag hade haft mitt första samtal med barnmorskan på mödrahälsovården

Annat:

17. Hur viktiga har olika faktorer varit för att du slutat dricka eller minskat din alkoholkonsumtion under graviditeten jämfört med tiden före? Samtal med andra gravida eller mödrar Samtal med partner, släkt, vänner och bekanta Media (Internet, tidningar, TV)

Annat:

$\begin{array}{ccccc}\begin{array}{c}\text { Mycket } \\ \text { viktigt }\end{array} & \begin{array}{c}\text { Ganska } \\ \text { viktigt }\end{array} & \begin{array}{c}\text { Inte särskilt } \\ \text { viktigt }\end{array} & \begin{array}{c}\text { Inte alls } \\ \text { viktigt }\end{array} & \begin{array}{c}\text { Ingen } \\ \text { uppfattning }\end{array} \\ \square & \square & \square & \square & \square \\ \square & \square & \square & \square & \square \\ \square & \square & \square & \square & \square \\ \square & \square & \square & \square & \square \\ \square & \square & \square & \square & \square\end{array}$

18. Vi ber dig att uppskatta din alkoholkonsumtion UNDER graviditeten (efter det att graviditeten blivit känd för dig), fram till idag!

A) Hur ofta har du druckit alkohol under graviditeten, fram till idag?

Aldrig $\rightarrow$ hoppa till fråga $19 !$

$1-2$ gånger under hela tiden

$\square 1$ gång i månaden

3-6 gånger under hela tiden

B) Hur många standardglas drack du en typisk dag då du drack alkohol under graviditeten, fram till idag?

$\square 1$ glas

$\square 2$ glas

3-4 glas

5-6 glas

7-9 glas

10 eller fler glas

C) Hur ofta har du druckit 4 standardglas eller mer vid eft och samma tillfälle under graviditeten, fram till idag?

Aldrig

Mer sällan än 1 gång i månaden

Varje månad
2-3 gånger i månaden

Varje vecka

Dagligen eller nästan varje dag 


\section{Vilket stöd har du från personer i din närhet? Hoppa över de 4 sista påståendena}

om du är ensamstående/singel!

Jag har goda vänner som stödjer mig Min famili ställer alltid upp för mig

Min partner hiälper mig mycket

Jag har en konflikt med min partner

Jag känner mig kontrollerad av min partner Jag känner mig älskad av min partner

20. Hur rökte eller snusade du INNAN graviditeten blev känd för dig?

Jag rökte eller snusade dagligen

Jag rökte eller snusade men inte dagligen

Jag har tidigare vanerökt eller vanesnusat men slutade innan graviditeten blev känd för mig Jag har aldrig vanerökt eller vanesnusat

\section{Hur har du rökt eller snusat hittills UNDER graviditeten?}

Jag har rökt eller snusat dagligen under graviditeten Jag har rökt eller snusat, men inte dagligen, under graviditeten

Jag har inte alls rökt eller snusat under graviditeten

22. Du får gärna skriva kommentarer här: 


\section{VÄNLIGEN STOPPA ENKÄTEN \\ I KUVERTET OCH LÄGG DET I KARTONGEN!}

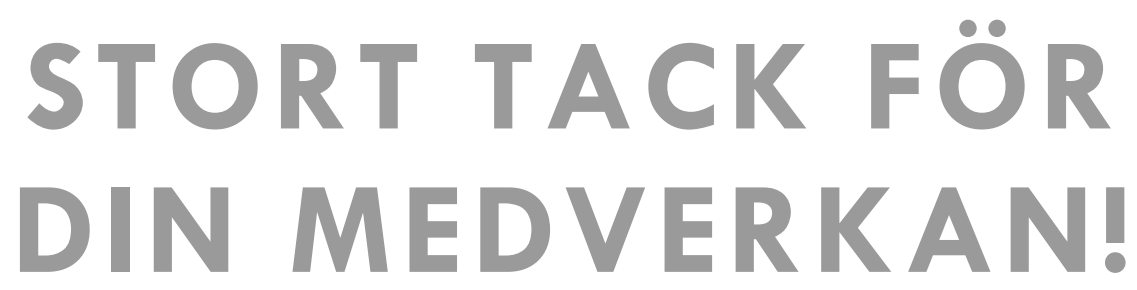


Appendix D 



\section{ALKOHOLKONSUMTION FÖRE OCH UNDER GRAVIDITET \\ KH 10 augusti 2009}

Denna enkät (4 sidor) handlar om rådgivning om alkohol till blivande mödrar och alkoholkonsumtion före och under graviditet. Två frågor handlar om tobak/snus. Enkäten sänds till alla mödrar som varit i kontakt med Kvinnohälsan och födde barn under en viss tid. Syftet är att få information om hur rådgivning från Kvinnohälsan till blivande mödrar ska kunna förbättras.

Du besvarar enkäten helt anonymt. Inga enskilda svar kommer att redovisas. Vi är tacksamma om du tar dig tid och besvarar frågorna så noggrant och ärligt som möjligt. Det är 16 frågor och tar cirka fem minuter.

\section{Hur gammal är du?}

19 år eller yngre 20-24 år

$$
\begin{aligned}
& 25-29 \text { år } \\
& 30-34 \text { ar }
\end{aligned}
$$

35-39 år

40 år eller äldre

\section{Vilken är din högsta utbildning?}

Grundskola

2-årigt gymnasium eller yrkesskola

3-4-årigt gymnasium

Universitet/högskola, 2,5 år eller kortare tid

Universitet/högskola, 3 år eller längre tid

\section{Civilstånd}

Gift eller sammanboende

Särbo

Ensamstående (singel)

\section{Hade du anställning när du blev gravid?}

Jag arbetade heltid

Jag arbetade deltid

Jag studerande

Jag var arbetslös

Annat:

\section{Har du fött barn tidigare?}

Ja $\mathrm{Nej}$ 


\section{Rökte eller snusade du innan graviditeten?}

Jag rökte eller snusade dagligen

Jag rökte eller snusade, men inte dagligen

Jag har tidigare rökt eller snusat, men inte 6 månader före jag blev gravid

Jag har aldrig varit rökare eller snusare

\section{Rökte eller snusade du under graviditeten?}

$\square$ Jag har rökt eller snusat dagligen under graviditeten

$\square$ Jag har rökt eller snusat, men inte dagligen, under graviditeten

Jag har inte alls rökt eller snusat under graviditeten

Frågorna nedan handlar om hur många "standardglas" man dricker - dessa frågor hänvisar till bilden nedan:

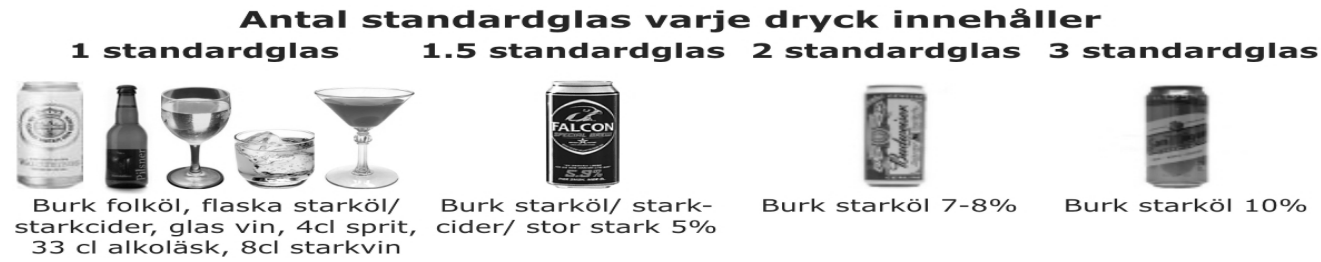

8. Vi ber dig, så gott det går, att uppskatta din alkoholkonsumtion före graviditeten blev känd för dig!

A) Hur ofta drack du alkohol före graviditeten?

$\square$ Aldrig $\rightarrow$ gå till fråga 11 !

1 gång i månaden eller mer sällan

2-4 gånger i månaden

2-3 gånger i veckan

4 gånger $i$ veckan eller oftare

B) Hur många "standarglas" drack du på en typisk dag då du drack alkohol före graviditeten?

$\square 1$ glas

$\square 2$ glas

3-4 glas

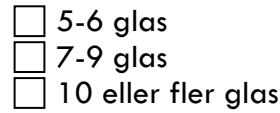

C) Hur ofta drack du 5 sådana "standardglas" eller mer vid ett och samma tillfälle före graviditeten?

\section{Aldrig}

Mer sällan än 1 gång i månaden

Varje månad

$\square$ Varje vecko

Dagligen eller nästan dagligen

\section{Upphörde du helt att dricka alkohol när du blev medveten om din graviditet?}

$\mathrm{Ja}$

$\mathrm{Nej}$

\section{När upphörde du att dricka alkohol?}

När jag planerade att bli gravid

När jag blev medveten om att jag var gravid

När jag haft mitt första samtal med barnmorskan på Kvinnohälsan 
11. Vi ber dig, så gott det går, att uppskatta din alkoholkonsumtion under graviditeten!

A) Hur ofta drack du alkohol under graviditeten?

Aldrig

1-2 gånger under hela tiden

3-6 gånger under hela tiden

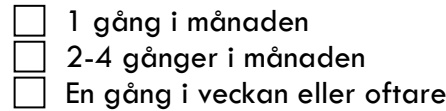

B) Hur många "standardglas" drack du på en typisk dag då du drack alkohol under graviditeten?
1 glas
2 glas
3-4 glas

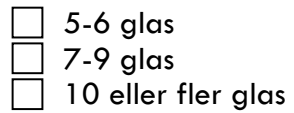

C) Hur ofta drack du 5 sådana "standardglas" eller mer vid ett och samma tillfälle under graviditeten? se bild på sidan 2 för förklaring av vad ett "standardglas" motsvarar!

Aldrig

Mer sällan än 1 gång i månaden

Varje månad $\square$ Varje vecka

Dagligen eller nästan dagligen

12. Om du minskade din alkoholkonsumtion under graviditeten jämfört med tiden före, vad anser du hade betydelse för denna förändring? Hoppa över frågan om du inte förändrade eller minskade din alkoholkonsumtion!

\section{Mycket}

viktigt

riskerna med att dricka alkohol under graviditet

Samtal med andra gravida eller mödrar om riskerna med att dricka alkohol under graviditet

Samtal med partner, släkt, vänner och bekanta om riskerna med att dricka alkohol under graviditet

Min partner minskade också sin alkohol-

konsumtion under tiden för min graviditet

Media (Internet, tidningar, TV) har giort mig medveten

om riskerna med att dricka alkohol under graviditet

\section{Ganska viktigt}

Inte särskilt Inte alls viktigt viktigt

Ingen

uppfattning

\section{Dessa frågor handlar om du har någon person $i$ din närhet som kan ge dig stöd $i$ olika situationer.}

Jag har goda vänner som stödjer mig

$\begin{array}{ccccc}\text { Aldrig } & \text { Sällan } & \text { lbland } & \text { Ofta } & \text { Alltid } \\ \square & \square & \square & \square & \square \\ \square & \square & \square & \square & \square \\ \square & \square & \square & \square & \square \\ \square & \square & \square & \square & \square \\ \square & \square & \square & \square & \square \\ \square & \square & \square & \square & \square\end{array}$


14. Den information och/eller de råd jag fick från Kvinnohälsan om alkohol uppfattade jag var:

Att helt avstå från alkohol under graviditeten

Att små mängder alkohol under graviditeten saknar betydelse

Oklara eller otydliga

Jag fick inte någon information eller råd

Annat:

15. Vad anser du om den information och/eller de råd om riskerna med att dricka alkohol under graviditeten du fick fràn Kvinnohälsan under graviditeten?

Instämmer Instämmer Instämmer Instämmer Ingen helt till stor del till viss del inte uppfattning

Jag har fått tillräckligt med information/råd om riskerna med att dricka alkohol under graviditeten Informationen/råden jag har fått om riskerna med att dricka alkohol under graviditet har varit tydliga Jag fick informationen/råden om riskerna med att dricka alkohol tillräckligt tidigt i graviditeten Informationen/råden jag har fått om riskerna med att dricka alkohol under graviditet har varit lätta att förstå

16. Hur nöjd är du med Kvinnohälsans insatser som helhet under din graviditet?

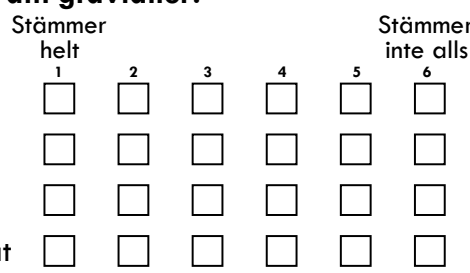

Jag ör helt nöjd med Kvinnohälsans insatser för mig

Det finns saker i Kvinnohälsans insatser som kunde vara bättre

Den tid Kvinnohälsan har ägnat mig är definitivt tillräcklig

Jag har inte haft så mycket kontakt med Kvinnohälsan som jag önskat

Kvinnohälsans personal har förklarat för mig varför olika undersökningar och tester genomförs

Kvinnohälsans personal kunde ha lyssnat bättre på mig

Kvinnohälsans personal har behandlat mig med respekt/värdighet

Kvinnohälsans personal kunde ha varit vänligare och/eller tagit mer hänsyn till mina känslor

Jag har väldigt stort förtroende för de personer jag har haft kontakt med på Kvinnohälsan

Jag ör lite treksam till kunskapsnivån hos en del av personalen på Kvinnohälsan

Kvinnohälsans insatser för mig gör att jag slipper oro och osäkerhet

Det finns vissa hälsofrågor som jag tycker Kvinnohälsan inte har

uppmärksammat tillräcklig
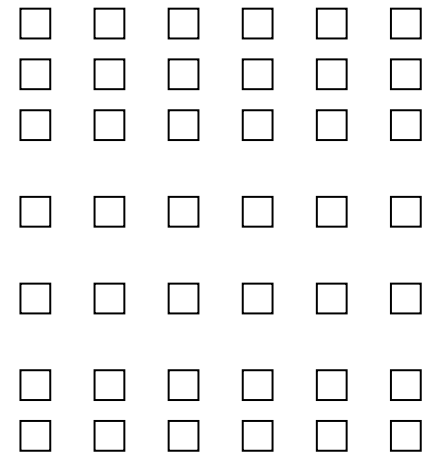

\section{Stort tack för din medverkan!}


Appendix 



\section{EN ENKÄT OM}

\section{ALKOHOL- OCH TOBAKSVANOR FÖRE OCH UNDER GRAVIDITET}

Denna enkät handlar om rådgivning om alkohol- och tobaksvanor till blivande mödrar och om alkohol- och tobaksvanor före och under graviditet. Enkäten sänds till alla mödrar som varit i kontakt med Kvinnohälsan och födde barn 2010-2011.

Du besvarar enkäten helt anonymt. Inga enskilda svar redovisas. Vi är tacksamma om du tar dig tid och besvarar frågorna så noggrant och ärligt som möjligt. Enkäten tar cirka 5 minuter att fylla i.

Projektet är ett samarbete mellan Kvinnohälsan och Linköpings universitet. Syftet med enkäten är bl.a. att få information om hur rådgivning från Kvinnohälsan till blivande mödrar ska kunna förbättras. Resultat är också tänkta att användas i vetenskapliga artiklar. 


\section{Först vill vi be dig svara på några frågor om din livssituation.}

1. Hur gammal är du?

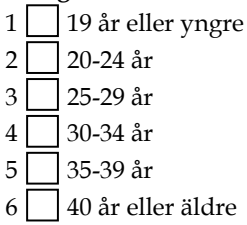

2. Vilken är din högsta avslutade utbildning? Om du studerar för närvarande, kan du kryssa i den utbildning du går nu!
$1 \square$ Grundskola (max 9 år), folkskola, realskola eller liknande
$2 \square$ 2-årigt gymnasium eller yrkesskola
$3 \square$ 3- eller 4-årigt gymnasium
$4 \square$ KY eller folkhögskola
$5 \square$ Universitet/högskola, mindre än 3 år
$6 \square$ Universitet/högskola, 3 år eller längre tid
$7 \square$ Annat:

3. Vad hade du för sysselsättning när du blev gravid?
$1 \square$ Jobbade, heltid
$2 \square$ Jobbade, deltid
$3 \square$ Studerade, praktiserade
$4 \square$ Föräldra- eller tjänstledig
$5 \square$ Arbetslös/arbetssökande
$6 \square$ Sjukskriven
$7 \square$ Annat:

4. Civilstånd när du blev gravid
$1 \square$ Gift eller sammanboende
$2 \square$ Särbo
$3 \square$ Ensamstående (singel)

5. Har du fött barn tidigare?

$1 \square$ Ja
$2 \square$ Nej




\section{Dessa frågor handlar om råd och information från Kvinnohälsan}

6. Vad anser du om den information eller de råd du fick från Kvinnohälsan om riskerna med att dricka alkohol under din graviditet?

$\begin{array}{ccccc}\begin{array}{c}\text { Instämmer } \\ \text { helt }\end{array} & \begin{array}{c}\text { Instämmer } \\ \text { till stor del }\end{array} & \begin{array}{c}\text { Instämmer } \\ \text { till viss del }\end{array} & \begin{array}{c}\text { Instämmer } \\ \text { inte }\end{array} & \begin{array}{c}\text { Ingen } \\ \text { uppfattning }\end{array} \\ 1 & 2 & 3 & 4 & 5\end{array}$

a. Jag fick tillräckligt med information och/eller

1

2

råd från Kvinnohälsan om riskerna med att

dricka alkohol under graviditet

b. Den information och/eller de råd jag fick

från Kvinnohälsan om riskerna med att

dricka alkohol under graviditet var lätta att

förstå och/eller tydliga

7. Den information och/eller de råd jag fick från Kvinnohälsan om alkohol uppfattade jag var:
$1 \square$ Att helt avstå från alkohol under graviditeten
$2 \square$ Att små mängder alkohol under graviditeten saknar betydelse
$3 \square$ Oklara eller otydliga
$4 \square$ Jag fick inte någon information eller råd om alkohol

$5 \square$ Annat:

\section{Frågorna nedan handlar om tobaksvanor}

8. Hur rökte eller snusade du INNAN graviditeten blev känd för dig?

$1 \square$ Jag rökte eller snusade dagligen

$2 \square$ Jag rökte eller snusade, men inte dagligen

$3 \square$ Jag har tidigare vanerökt eller vanesnusat, men slutade innan graviditeten blev känd för mig

$4 \square$ Jag har aldrig vanerökt eller vanesnusat

9. Hur rökte eller snusade du UNDER graviditeten?
$1 \square$ Jag rökte eller snusade dagligen under graviditeten
$2 \square$ Jag rökte eller snusade, men inte dagligen, under graviditeten
$3 \square$ Jag rökte eller snusade inte alls under graviditeten

\section{Frågorna om alkohol börjar här}

10. I Sverige har alkoholkonsumtionen ökat totalt sett, men andelen gravida som dricker har minskat. Vad tror du detta beror på?

$\begin{array}{ccccc}\begin{array}{c}\text { Instämmer } \\ \text { helt }\end{array} & \begin{array}{c}\text { Instämmer } \\ \text { till stor del }\end{array} & \begin{array}{c}\text { Instämmer } \\ \text { till viss del }\end{array} & \begin{array}{c}\text { Instämmer } \\ \text { inte }\end{array} & \begin{array}{c}\text { Ingen } \\ \text { uppfattning }\end{array} \\ 1 & 2 & 3 & 4 & 5\end{array}$

a. Jag tror denna minskning beror på en allmänt ökad medvetenhet i samhället om riskerna med att dricka alkohol under graviditet

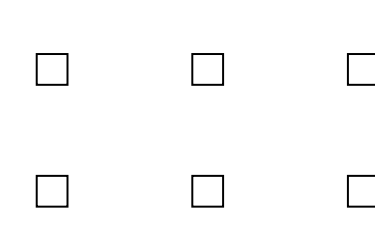


Ett standardglas motsvarar något av nedanstående:

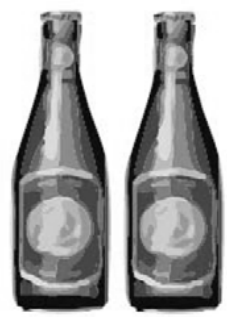

2 sł 33 cl lättöl

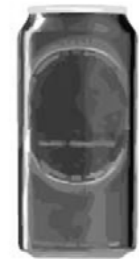

50 el folköl

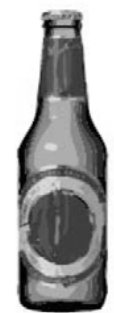

33 el starköl starkcider, alkoläsk

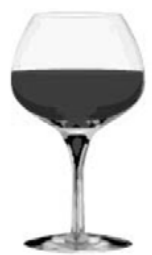

1 litet glas rött / vitt vin (15 cl)

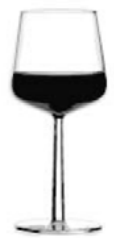

$8 \mathrm{el} \mathrm{starkvin}$

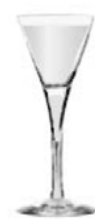

4 el sprit

Vi ber dig uppskatta din alkoholkonsumtion INNAN graviditeten blev känd för dig!

11. Hur ofta drack du alkohol före graviditeten?
$1 \square$ Aldrig $\rightarrow$ HOPPA TILL FRÅGA 15!
$2 \square 1$ gång i månaden eller mer sällan
$3 \square$ 2-4 gånger i månaden
$4 \square$ 2-3 gånger i veckan
$5 \square 4$ gånger i veckan eller oftare

12. Hur många standardglas drack du på en typisk dag då du drack alkohol före graviditeten?
$1 \square 1$ standardglas
$2 \square 2$ standardglas
$3 \square$ 3-4 standardglas
$4 \square$ 5-6 standardglas
$5 \square$ 7-9 standardglas
$6 \square 10$ eller fler standardglas

13. Hur ofta drack du $\underline{4}$ standardglas eller mer, vid ett och samma tillfälle, före graviditeten?
$1 \square$ Aldrig
$2 \square$ Mer sällan än 1 gång i månaden
$3 \square$ Varje månad
$4 \square$ 2-3 gånger i månaden
$5 \square$ Varje vecka
$6 \square$ Dagligen eller nästan varje dag

14. Hur ofta drack du 5 standardglas eller mer, vid ett och samma tillfälle, före graviditeten?
$1 \square$ Aldrig
$2 \square$ Mer sällan än 1 gång i månaden
$3 \square$ Varje månad
$4 \square$ 2-3 gånger i månaden
$5 \square$ Varje vecka
$6 \square$ Dagligen eller nästan varje dag 
15. OM du minskade din alkoholkonsumtion i samband med graviditeten, NÄR gjorde du det?

$1 \square$ När jag planerade att bli gravid

$2 \square$ När jag blev medveten om att jag var gravid

$3 \square$ När jag hade haft mitt första samtal med barnmorskan på mödrahälsovården

$4 \square$ Annat:

16. Upphörde du att dricka alkohol när du blev medveten om din graviditet?

$1 \square$ Ja $\rightarrow$ HOPPA TILL FRÅGA 21!

$2 \square$ Nej

Vi ber dig uppskatta din alkoholkonsumtion UNDER graviditeten, det vill säga efter det att graviditeten blev känd för dig!

17. Hur ofta drack du alkohol under graviditeten?
$1 \square$ 1-2 gånger under hela tiden
2 3-6 gånger under hela tiden
$3 \square 1$ gång i månaden
$4 \square$ 2-4 gånger i månaden
$5 \square$ En gång i veckan eller oftare

18. Hur många standardglas drack du på en typisk dag då du drack alkohol under graviditeten?
$1 \square 0,5$ standardglas
$2 \square 1$ standardglas
$3 \square 2$ standardglas
$4 \square$ 3-4 standardglas
$5 \square$ 5-6 standardglas
$6 \square$ 7-9 standardglas
$7 \square 10$ eller fler standardglas

19. Hur ofta drack du $\underline{4}$ standardglas eller mer, vid ett och samma tillfälle, under graviditeten?
$1 \square$ Aldrig
$2 \square$ Mer sällan än 1 gång i månaden
$3 \square$ Varje månad
$4 \square$ 2-3 gånger i månaden
$5 \square$ Varje vecka
$6 \square$ Dagligen eller nästan varje dag

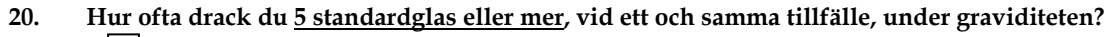
$1 \square$ Aldrig
$2 \square$ Mer sällan än 1 gång i månaden
$3 \square$ Varje månad
$4 \square$ 2-3 gånger i månaden
$5 \square$ Varje vecka
$6 \square$ Dagligen eller nästan varje dag 
21. Hur pass svårt eller enkelt var det för dig att minska din alkoholkonsumtion under graviditeten?
$1 \square$ Jag förändrade inte min alkoholkonsumtion under graviditeten
$2 \square$ Det var mycket lätt
$3 \square$ Det var ganska lätt
$4 \square$ Det var ganska svårt
$5 \square$ Det var mycket svårt
$6 \square$ Ingen uppfattning

22. Om du minskade din alkoholkonsumtion under graviditeten jämfört med tiden före, vad anser du hade störst betydelse för denna förändring? Hoppa över frågan om du inte förändrade eller minskade din alkoholkonsumtion!

Kvinnohälsans information och/eller råd

$\begin{array}{cc}\text { Mycket } & \text { Ganska } \\ \text { viktigt } & \text { viktigt } \\ 1 & 2\end{array}$
Inte särskilt Inte alls viktigt viktigt
4

23

Ingen uppfattning

5

om riskerna med att dricka alkohol under graviditet

b. Samtal med andra gravida eller mödrar om riskerna med att dricka alkohol under graviditet

c. Samtal med partner, släkt, vänner och bekanta om riskerna med att dricka alkohol under graviditet

d. Min partner minskade också sin konsumtion under tiden för min graviditet

e. Media (Internet, tidningar, TV, etc.) har gjort mig mer medveten om riskerna med att dricka alkohol under graviditet

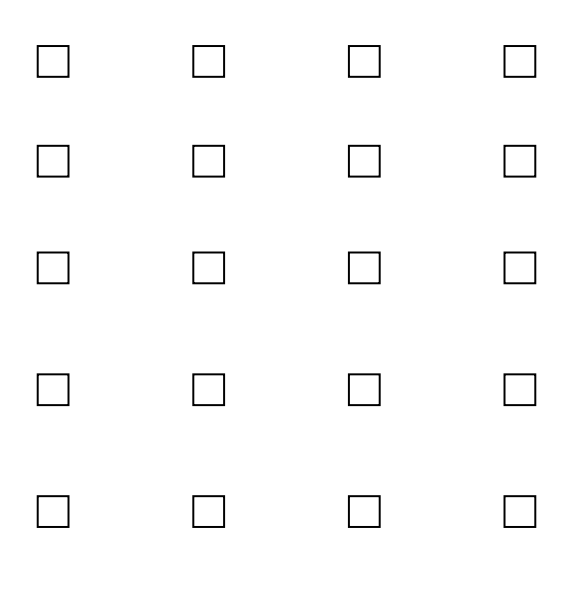


Appendix 



\section{Frågeguide}

\section{Alkoholkonsumtion i samband med graviditet - uppfattningar bland icke-gravida kvinnor i fertil ålder.}

Syftet med studien är att utforska uppfattningar kring alkoholkonsumtion under graviditet och tiden kring befruktning bland icke-gravida kvinnor i fertil ålder. Projektet syftar till att besvara ett antal angelägna frågeställningar kring alkoholkonsumtion under olika skeden kring befruktning och under graviditet samt kunskap om effekter av alkoholkonsumtion under graviditet.

\section{Öppningsfråga}

Berätta vad ni heter, hur ni blev rekryterade/varför ni valde att komma hit idag.

\section{Introduktionsfråga}

Bild 1. På den här bilden ser ni ett glas som innehåller alkohol. Jag tänkte att vi ska börja med att prata generellt om alkohol, vad tänker ni när ni ser bilden?

- Vilka fördelar finns det med alkohol?

- Vilka risker finns med alkohol?

- Vad tänker ni på när jag säger alkoholvanor?

- Vad har ni för tankar när det gäller alkoholbruk?

- Vad har ni för tankar när det gäller riskbruk?

- Vad har ni för tankar när det gäller missbruk?

\section{Övergångsfråga}

Bild 2. På den här bilden ser ni kvinnor/tjejer som dricker alkohol. Vad får ni för tankar när ni tittar på bilden?

- Av vilka anledningar dricker vi alkohol?

- Är det skillnad på kvinnor som dricker alkohol och män som dricker alkohol?

- Vilka normer finns runt alkoholkonsumtion?

- Hur tänker ni kring berusning?

- Hur tänker ni kring riskkonsumtion av alkohol?

- Vad tänker ni kring sexuellt risktagande?

\section{Nyckelfrågor}


Bild 3. Nu kommer vi in på det här med alkohol och graviditet. De här bilderna visar ett positivt graviditetstest och en inbjudan till personalfest, vad tänker ni när det ser dem?

- Vad säger ni om socialt tryck när det gäller alkohol?

- Vad tänker ni kring normer när det gäller alkohol?

- Hur påverkas ett foster av alkohol?

- När börjar mammans ansvar för barnet? - försök att bli gravid, befruktningsögonblicket, tidig grav.,medvetenhet?

Bild 4: Här ser ni en gravid kvinna som tar ett glas vin. Vilka tankar fär ni när ni ser den här bilden?

- Vad tänker ni om socialt tryck i denna situation?

- Vad finns det för normer kring att alkoholkonsumtion under graviditet?

- Vilka effekter kan alkohol ha på ett foster?

- Vilka effekter kan alkohol ha på modern?

- Hur tänker ni kring att dricka små mängder jämfört med stora mängder?

- Är det var och ens personliga val om de vill dricka alkohol eller inte?

Picture sorting.

Moderatorn eller bisittaren lägger fram flera bilder på kvinnor hämtade från tidningar och dylikt och ber deltagarna att sortera bilderna i två högar, en med kvinnor som ni tror skulle dricka under sin graviditet och en med kvinnor som ni tror skulle avstå. När deltagarna är klara ställs frågan:

Vad var det med bilderna som fick er att lägga dem i de olika högarna?

\section{Slutfrågor}

Avslutning - moderatorn repeterar syftet med studien

Av allt vi har diskuterat idag, vad tycker ni är det viktigaste?

Är det något ni tycker att vi borde ha pratat om här idag som inte har kommit upp? 
Bild 1

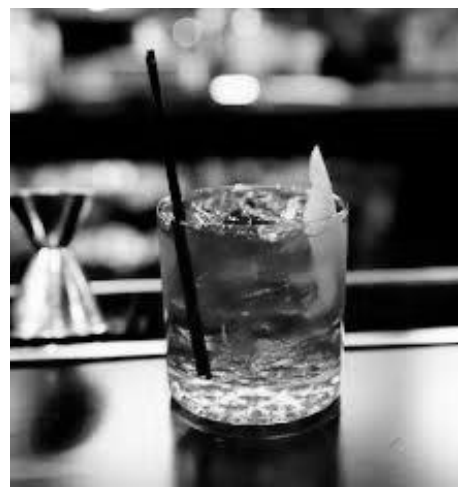

Bild 2

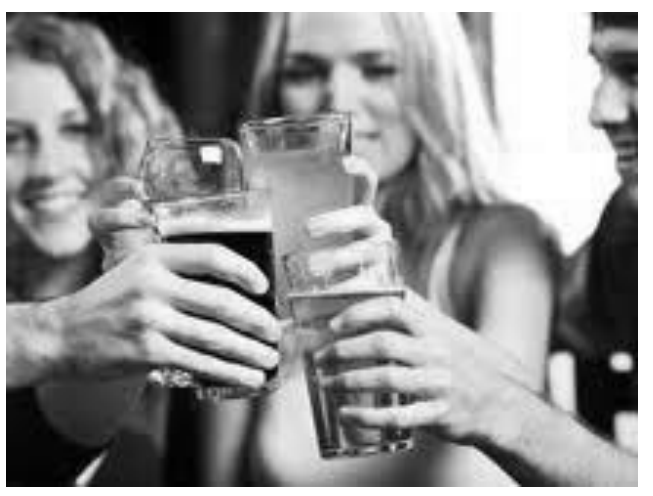

Bild 3
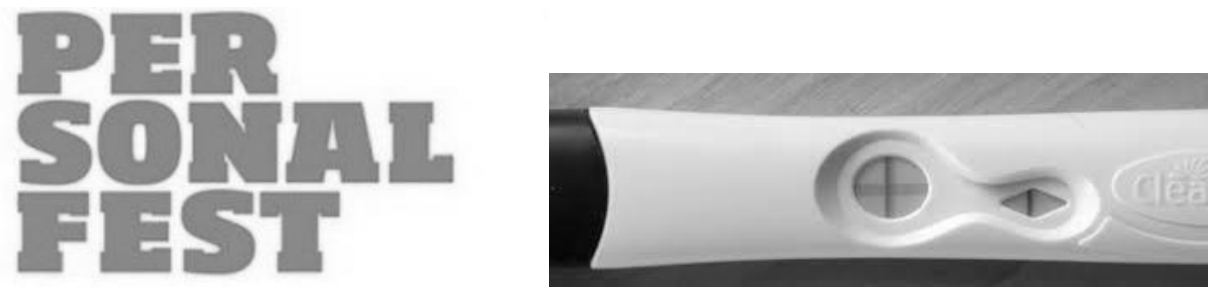

Bild 4

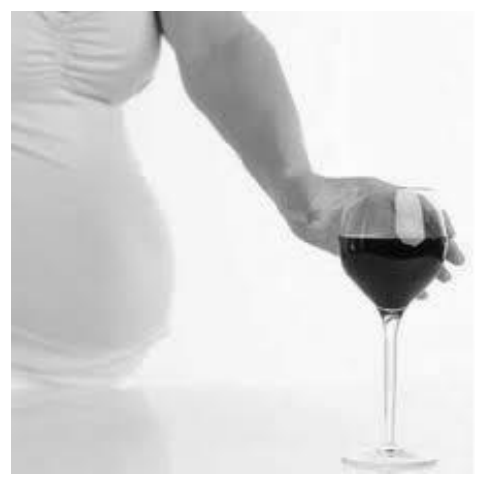





\section{Papers}

The articles associated with this thesis have been removed for copyright reasons. For more details about these see:

http://urn.kb.se/resolve?urn=urn:nbn:se:liu:diva-122375 